\title{
Sharing the water column: physiological mechanisms underlying species-specific habitat use in tunas
}

DOI:

10.1007/s11160-017-9497-7

\section{Document Version}

Accepted author manuscript

Link to publication record in Manchester Research Explorer

\section{Citation for published version (APA):}

Bernal, D., Brill, R. W., Dickson, K. A., \& Shiels, H. (2017). Sharing the water column: physiological mechanisms underlying species-specific habitat use in tunas. Reviews in Fish Biology and Fisheries.

https://doi.org/10.1007/s11160-017-9497-7

\section{Published in:}

Reviews in Fish Biology and Fisheries

\section{Citing this paper}

Please note that where the full-text provided on Manchester Research Explorer is the Author Accepted Manuscript or Proof version this may differ from the final Published version. If citing, it is advised that you check and use the publisher's definitive version.

\section{General rights}

Copyright and moral rights for the publications made accessible in the Research Explorer are retained by the authors and/or other copyright owners and it is a condition of accessing publications that users recognise and abide by the legal requirements associated with these rights.

\section{Takedown policy}

If you believe that this document breaches copyright please refer to the University of Manchester's Takedown Procedures [http://man.ac.uk/04Y6Bo] or contact uml.scholarlycommunications@manchester.ac.uk providing relevant details, so we can investigate your claim.

\section{OPEN ACCESS}




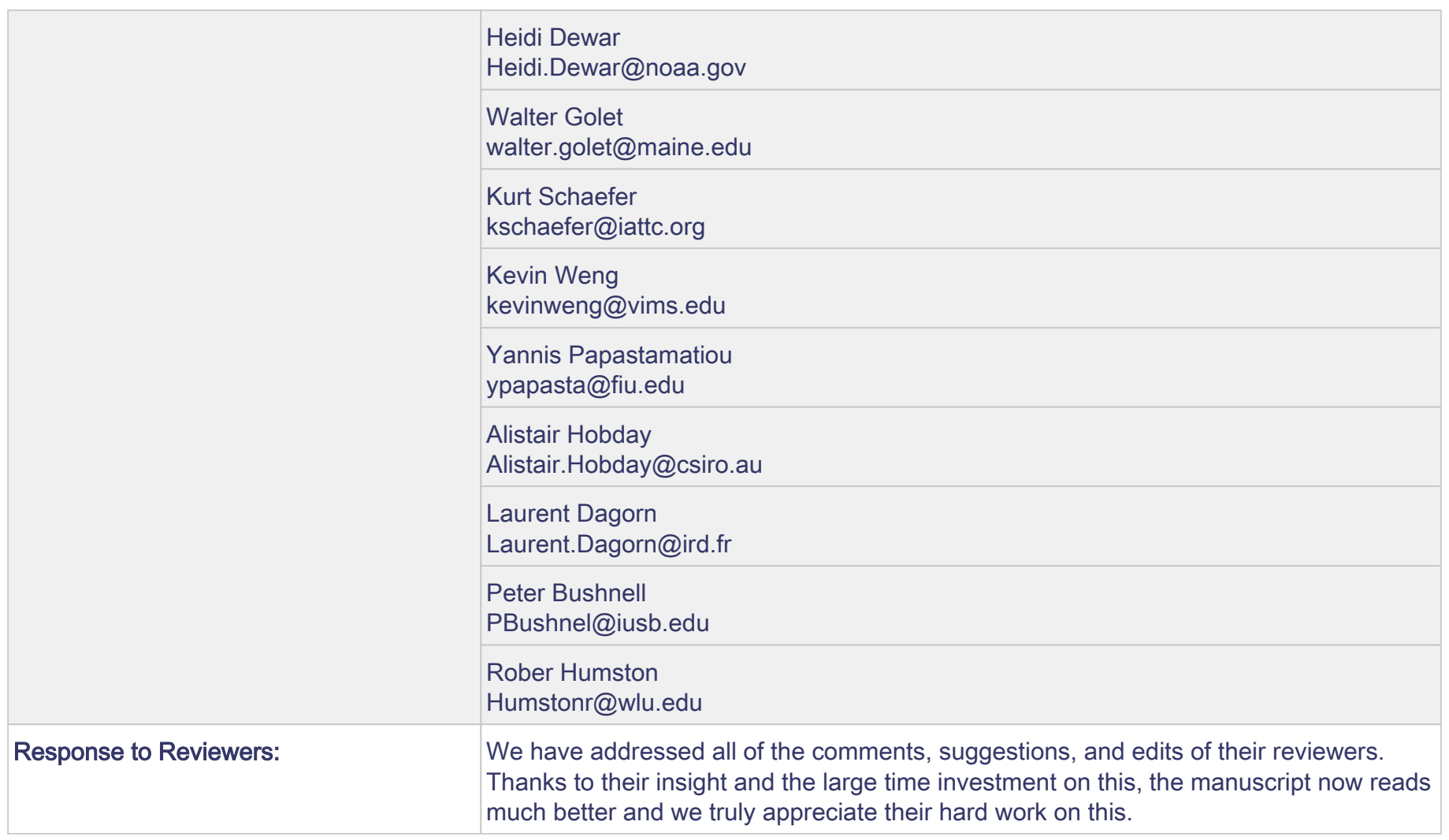


Click here to view linked References

3

\section{Sharing the water column: Physiological mechanisms underlying species-specific habitat}

2 use in tunas

3

4 Diego Bernal, Richard W. Brill, Kathryn A. Dickson, Holly A. Shiels

5

6 Diego Bernal

7 Department of Biology, University of Massachusetts Dartmouth, Dartmouth, MA 02790, USA

9 Richard W. Brill

10 Fisheries Ecology Branch, Ecosystems \& Aquaculture Division, Northeast Fisheries Science

11 Center, National Marine Fisheries Service, NOAA, Sandy Hook, NJ, 07732, USA

12

13 Richard W. Brill

14 Virginia Institute of Marine Science, College of William and Mary, Gloucester Point, VA 23062 ,

15 USA

16

17 Kathryn A. Dickson

18 Department of Biological Science, California State University Fullerton, Fullerton, CA, 92834, 19 USA

21 Holly A. Shiels, Faculty of Biology, Medicine and Health, University of Manchester,

22 Manchester, M13 9NT, UK 
25 Abstract

26 Tuna species support some of the world's largest commercial and recreational fisheries. Their 27 extensive migratory patterns expose them to multiple national and international fisheries and 28 fishery management regimes. Several prized species have become the focus of global 29 conservation efforts and there is a growing worldwide interest in establishing optimal strategies 30 for sustainable tuna fisheries. Although this task has proven to be very challenging, it has taken 31 on a new sense of urgency in the face of the potential effects of global climate change. A better 32 understanding of the interactions between environmental conditions and tuna physiology and 33 how they affect tuna behavior will offer population and stock assessment modelers and fisheries 34 biologists a more mechanistic understanding of tuna distribution patterns and may help predict 35 changes in both geographic and depth-related movement patterns. Indeed, physiological data 36 comprise a growing component of multi-trait analysis approaches to species conservation. Our 37 review aims to summarize what is known about differences among tuna species in distribution 38 patterns, tolerances to environmental conditions, and physiological characteristics that correlate 39 with the capacity to inhabit cooler (deeper, higher latitude) and even hypoxic waters. To achieve 40 this goal, we discuss how these physiological traits are associated with habitat partitioning within 41 the three-dimensional oceanic environment and with niche expansion into cooler and hypoxic 42 waters. We also point out areas where additional research is needed to predict more accurately 43 how future changes in oceanographic conditions will affect the distributions and movement 44 patterns of tunas and their availability to fisheries. 45

46 Keywords Swimming, metabolism, endothermy, hypoxia, thermoregulation, cardiac physiology, 47 vision, digestion, movement patterns, diving 48 


\section{Introduction}

\section{Tuna biogeography and evolution}

The 15 extant species of tunas (five genera: Allothunnus, Auxis, Euthynnus, Katsuwonus, Thunnus) form a monophyletic group (Tribe Thunnini) that differs morphologically and physiologically from their closest relatives, the bonitos (Tribe Sardini), within the Family Scombridae (Collette 1978; Altringham and Block 1997; Graham and Dickson 2000; Collette et al. 2001; Westneat and Wainwright 2001; Dowis et al. 2003; Sepulveda et al. 2003; Ciezarek et al. 2016) (Figure 1a). Molecular phylogenies place Auxis, Euthynnus, and Katsuwonus in a group separate from the most derived and speciose genus, Thunnus (Block et al. 1993; Chow and Kishino 1995; Chow et al. 2006; Collette et al. 2001; Orrell et al. 2006; Miya et al. 2013). Overall, tunas have wide geographic distributions, ranging from the tropics to latitudes as high as $72^{\circ}$ North and $58^{\circ}$ South, and are found in coastal and pelagic waters. Several tuna species are limited to warm waters $\left(\geq 20^{\circ} \mathrm{C}\right)$ and either remain within a specific tropical ocean basin (e.g., blackfin tuna, Thunnus atlanticus, and longtail tuna, T. tonggol), or are circumtropical (e.g., skipjack tuna, Katsuwonus pelamis, and yellowfin tuna, T. albacares). Other tunas spend considerable time in colder waters (e.g., below $18^{\circ} \mathrm{C}$ ) as they migrate to high latitudes (e.g., Atlantic bluefin, T. thynnus, and southern bluefin, T. maccoyii) or routinely dive below the thermocline (e.g., bigeye tuna, T. obesus). Only one tuna species, the basal slender tuna (Allothunnus fallai) occurs primarily within the temperate waters of the Southern Ocean (reviewed in Collette and Nauen 1983).

While fossil evidence suggests that the Thunnini and Sardini diverged approximately 60 million years ago (mya) in the early Tertiary (Bannikov 1985; Carroll 1988; Monsch 2000), a recent molecular phylogenetic study (Miya et al. 2013) estimated the divergence time at 6-17 mya and proposed 61.6 mya as the origin of the Scombridae. Nonetheless, paleoceanographic evidence suggests that these fishes evolved in a tropical environment that progressively cooled starting at approximately 35-50 mya, resulting in increased vertical thermal stratification at lower latitudes and upwelling at higher latitudes (Berger 1981; Macdougall 1996; Lyle et al. 2008). The warm and well-oxygenated surface layer of the tropical oceans inhabited by ancestral tunas became geographically compressed, and areas of higher primary productivity developed at high latitudes. As a result, there would have been strong selective pressure for ancestral tunas to expand their distribution into more temperate environments where they would encounter high 
81 prey densities allowing high rates of somatic and gonadal growth (i.e., increased larval survival 82 rates and fecundity). The need to swim long distances to reach those productive foraging areas is 83 proposed to have been a factor in the evolution of a suite of morphological and physiological 84 characteristics that allowed tunas to migrate long distances and exploit cooler waters (reviewed 85 by Graham and Dickson 2001; Dickson and Graham 2004). These adaptations include regional 86 endothermy, the ability to retain metabolic heat and maintain the temperature of certain tissues 87 (slow-oxidative locomotor muscle or red muscle, visceral organs, and eye and brain) above water 88 temperature (reviewed in Carey et al. 1971; Block 1991; Graham and Dickson 2004). Even though some tuna species have expanded their distributions into higher latitudes or deeper waters, their reproductive biology reflects a tropical origin in that all tunas (except Allothunnus fallai) spawn in warm waters, with a sea surface temperature of at least $24^{\circ} \mathrm{C}$ (Schaefer 2001). The warm-water species spawn throughout the year, and the subtropical or temperate-water species undergo seasonal migrations to warmer waters to spawn (Schaefer 2001; Muhling et al. 2017).

Although the geographic distributions of several extant tuna species overlap, there are several lines of evidence demonstrating at least some degree of habitat partitioning. For example, Japanese longline catch data for tunas in the tropical central Pacific Ocean from the 1970s show that catches of skipjack, yellowfin, albacore (T. alalunga), and bigeye tunas peaked at different depths - near the surface, at depths of $125 \mathrm{~m}, 200 \mathrm{~m}$, and the deepest waters fished by the longlines, respectively (Hanamoto 1987; Sharp 2001) - suggesting habitat partitioning by depth in regions where these four tuna species co-occur. Furthermore, the most recent phylogenies based on mitochondrial and nuclear DNA sequence data (Miya et al. 2013; Díaz-Arce et al. 2016; Suzuki and Chow 2016) indicate that thermal niche expansion into cooler waters may have occurred more than once among the Thunnus species (Figure 1a). The main focus of our review is to summarize the physiological characteristics that have allowed some tuna species to inhabit cooler waters at higher latitudes or depth, thus contributing to niche expansion or habitat partitioning within the three-dimensional oceanic environment.

Because the oceans are thermally stratified, and other environmental characteristics such as dissolved oxygen (DO) concentration, pressure, light intensity and quality, and prey abundance vary with depth, latitude, as well as seasonally, it is essential to understand the spatial and temporal movement patterns of tunas and to measure the corresponding environmental 
112 conditions they encounter (Deary et al. 2015). In addition, the physiological tolerance limits of 113 different tuna species must be understood mechanistically, in order to associate behavior and 114 distribution patterns with interspecific differences in physiological capacities (Horodysky et al. 115 2015, 2016). Obtaining the data needed to test such associations in multiple species has been 116 challenging because they are large, active pelagic animals with a worldwide distribution.

117 However, over the last few decades, studies with archival tags, at shoreside facilities, and with 118 fish maintained in at-sea floating enclosures have made it possible to begin to address such 119 questions. Establishing relationships between environmental conditions and tuna physiology and 120 behavior will help population and stock assessment modelers and fisheries biologists to predict distributions more accurately, even as oceanographic conditions change due to climate change (e.g., Lehodey et al. 2011; McKenzie et al. 2016), and to implement optimal strategies for sustainable tuna fisheries.

\section{Movement patterns of tunas}

Species-specific movement patterns of tunas can be inferred by analyzing latitudinal, temporal, and vertical (i.e., depth) distributions based on conventional fisheries data and acoustic or archival tagging data (e.g., Collette and Nauen 1983; Block et al. 1998; Gunn and Block 2001; Musyl et al. 2003; Bestley et al. 2009; Schaefer et al. 2009). Although the distributions of some tunas do show clear interspecific seasonal latitudinal differences (e.g., skipjack tuna versus Atlantic bluefin tuna), some species co-occur throughout the entire year (e.g., skipjack and yellowfin tunas in the eastern Pacific Ocean) or seasonally during spawning (e.g., blackfin and Atlantic bluefin tunas in the Gulf of Mexico). There are also differences in day-night depth distributions. During the nighttime, most tunas remain within the well-mixed surface layer above the thermocline, which is warm and well-oxygenated, leading to substantial overlap in their vertical distributions (e.g., Carey and Robinson 1981; Holland et al. 1990b; Schaefer and Fuller 2002; Musyl et al. 2003). In contrast, during daylight hours different tuna species may occupy different parts of the water column, with some species able to move into deeper, colder, and often hypoxic waters and others remaining in the surface layer (Figure 2). These day-night differences are most likely associated with the daily nocturnal vertical migration of the prey associated with the deep sound-scattering layer (DSL; Dagorn et al. 2000), the importance of vision during prey capture (e.g., Fritsches et al. 2003, 2005; Brill et al. 2005), and interspecific 
differences in physiological tolerances for conditions at depth. For this review, we have divided tuna species into three groups based on the extent of their vertical and latitudinal movements (Bernal et al. 2009; Bernal 2011):

\section{Vertical movement behavior Group 1 -- tunas that spend the majority of their time in the well-} mixed surface layer above the thermocline

Group 1 tunas are consistently found in the upper layers of the ocean where the water column is well oxygenated and forms a thermally homogenous layer above the thermocline, with water temperatures generally above $20^{\circ} \mathrm{C}$ (Figures $2,3 \mathrm{a}$ ). The vertical movements of these species are limited by the presence of the thermocline (Figure 3c), the depth of which varies and is influenced by ocean-basin-specific oceanography. Group 1 species remain both day and night within the warm surface layer and rarely descend to waters with temperatures below $20^{\circ} \mathrm{C}$. Members of the genera Auxis and Euthynnus and small yellowfin and skipjack tunas best exemplify this group (Dizon et al. 1978; Collette and Nauen 1983). Interestingly, the vertical movement behaviors of some species (e.g., skipjack and yellowfin tunas) change as they grow, with smaller individuals $(<4 \mathrm{~kg}$ ) usually remaining within the surface layer of the ocean (i.e., Group 1) and larger individuals undertaking brief sojourns below the thermocline (i.e., Group 2; Figures 2, 3b). This size-related difference implies that these species may become more tolerant of cooler, less-well oxygenated waters as they grow larger.

\section{Vertical movement behavior Group 2 -- tunas that undergo short excursions below the} thermocline

Group 2 tunas (larger yellowfin and skipjack tunas) move from the surface layer during infrequent (one to several per day), short-duration descents to depths below the thermocline (e.g., Block et al. 1997; Schaefer et al. 2007; Schaefer and Fuller 2007) (Figures 3b, 4a). In general, Group 2 species spend the majority of the daylight hours above the thermocline, occasionally diving to or below the thermocline, and do not occur in cooler surface waters at high latitudes. The greater vertical movements exhibited by members of this group compared with Group 1 tunas expose them to a much wider thermal range (i.e., water temperatures below $10^{\circ} \mathrm{C}$ ), lower light levels, and, in some geographic areas, hypoxic waters - but only for brief periods. In addition, some Group 2 tunas show diurnal vertical movement patterns, descending to deeper 
depths during daylight hours and returning to shallower depths at night. Thus, tuna species in Group 2 tolerate wider ranges of environmental conditions than do those in Group 1.

\section{Vertical movement behavior 3 (Group 3) -- tunas that make frequent excursions below the thermocline or migrate to high latitudes}

Tuna species in Group 3 have the widest thermal and latitudinal ranges, with some frequently descending below the thermocline to temperatures as low as $5^{\circ} \mathrm{C}$ and others being exposed to cold waters at high latitudes for prolonged periods of time during their seasonal migrations. Members of this group include the Atlantic and southern bluefin tunas, which remain al. 2001; Gunn and Block 2001) (Figure 4b), and the slender tuna which resides permanently in cold water in the Southern Ocean (Collette and Nauen 1983). Other Group 3 species (e.g., bigeye tuna; Holland et al. 1992; Schaefer and Fuller 2010) make regular and frequent deep descents during the day (Figure 4b), with incursions into the oxygen minimum zone where water DO concentration is below $2 \mathrm{mg} \mathrm{O}_{2} \mathrm{~L}^{-1}$; these species tolerate hypoxia for extended periods. Furthermore, deep-diving species are almost continuously (day and night) exposed to low light levels. Thus, Group 3 tunas experience a much wider range of environmental conditions than do the other tuna species.

Although we can divide tunas into the above three groups based on depth distributions and vertical movement patterns, there is no evidence for absolute depth preferences in any tuna species. Instead, movement patterns appear to depend more on prey availability, reproductive migrations, and physiological capacities than on depth per se. Tunas and their prey inhabit a dynamic environment in which oceanographic conditions affect light penetration, water clarity, water temperature, deep-water mixing, nutrient availability (i.e., primary productivity), and DO concentration. Thus, changes in local or basin-wide oceanographic conditions will have a marked effect on the depth distribution of both tunas and their prey (e.g., Prince and Goodyear 2007, Prince et al. 2010; Lehodey et al. 2011; Schirripa et al. 2016; Yen and Lu 2016), and all of these factors and their interactions must be taken into account in predicting tuna behavior. Some prey species (e.g., cephalopods, crustaceans, vertically migrating fishes) move to deeper, colder waters during the daylight hours where light penetration and DO are limited, thus offering some 
refuge from predation (e.g., Drazen and Seibel 2007). Consequently, if tunas seek to exploit those prey during the day, they must be able to meet the metabolic demands involved in descending to depth, searching for prey, and recovering from any bout of burst activity associated with prey capture, all while being exposed to a cold and often hypoxic environment. Moreover, the senses that tunas rely on for prey detection (e.g., sight, smell, and hearing) must remain functional under cold, hypoxic, and relatively low-light conditions. Thus, the tuna species in Group 3, which have the greatest depth and latitudinal ranges, are expected to have physiological adaptations and broader tolerances associated with their ability to move into colder, deeper, darker, and hypoxic waters in search of prey. We therefore focus the remainder of our review on what is currently known about these physiological characteristics and how they differ interspecifically.

\section{Swimming, muscle endothermy and thermoregulation}

Tunas rely on continuous forward swimming to generate hydrodynamic lift and to pass water over their gills to support ram ventilation (Magnuson 1973, 1978; Magnuson and Weininger 1978; Alexander 1993). Relative to closely related taxa, all tunas possess morphological specializations that increase body streamlining and decrease drag [i.e., the slowoxidative locomotor red muscle (RM) is located centrally (closer to the vertebrae) and has a more anterior distribution; Figure 1b, c], reducing locomotor costs (reviewed in Bernal et al. 2001, 2009), but some features related to swimming do vary interspecifically. For example, the species of the genera Auxis, Euthynnus, and Katsuwonus, all of which are relatively small and lack a swim bladder as adults (Collette 1978), have smaller total lift surface areas and higher minimum hydrostatic speeds compared to the members of the genus Thunnus (Magnuson 1978). The potential increased cost of generating hydrodynamic lift in those species correlates with a greater relative amount of RM which powers continuous swimming (Magnuson 1978; Graham et al. 1983; Dickson 1996; Graham and Dickson 2000). It does not appear, however, that swimming capacity either correlates with, or poses a limitation for, vertical or horizontal movements of tunas except as related to fish size.

Interspecific differences in the pattern of blood flow to and from the RM may be related to the ability of some tuna species to tolerate rapid changes in water temperature during dives below the thermocline or to remain longer in cool, deep waters (Graham and Dickson 2001). In 
tunas, as in other fishes, oxygenated blood from the gills flows via the dorsal aorta to the locomotor muscles and other tissues, and deoxygenated blood returns from the tissues to the heart via the posterior cardinal vein and then is pumped to the gills (Harder 1975). Tunas have evolved central and lateral vascular counter-current heat exchangers, or retia mirabilia, composed of numerous parallel arterioles and venules that perfuse the RM (Kishinouye 1923; Carey and Teal 1969; Sharp and Dizon 1978; Bushnell et al. 1992; Graham and Dickson 2001). As warmed, deoxygenated blood flows away from the muscle through the rete venules, heat is transferred to oxygenated blood in the adjacent rete arterioles, retaining metabolic heat produced within the RM during sustained swimming, which would otherwise be lost to the environment as blood passes through the gills. These vascular heat exchangers enable all tuna species to maintain $\mathrm{RM}$ temperatures $\left(\mathrm{T}_{\mathrm{RM}}\right)$ that are elevated significantly above ambient water temperature ( $\mathrm{T}_{\mathrm{a}}$ ) (Figure 5) (Carey and Teal 1966; Carey and Lawson 1973; Brill et al. 1994; Stevens et al. 2000; Bernal et al. 2001; Marcinek et al. 2001; Dickson and Graham 2004). The basal slender tuna has only a central circulation that supplies blood to the RM via the dorsal aorta and post cardinal vein through the central vascular heat exchanger (Graham and Dickson 2000). All other tunas have an additional lateral circulation (via lateral arteries and veins and the associated lateral vascular heat exchangers) that provides another route for blood flow to and from the RM (Kishinouye 1923; Carey and Teal 1969; Sharp and Dizon 1978, Bushnell et al. 1992, Bernal et al. 2001, Graham and Dickson 2000, 2001; Figure 1b). Some Thunnus species lack a central rete (Collette et al. 2001), and those species should have a greater capacity to thermoregulate physiologically by adjusting the relative amount of blood flow to the RM via the lateral vascular heat exchangers and the dorsal aorta.

The conservation of heat by the RM vascular heat exchangers allows tunas to maintain elevated and more stable locomotor muscle temperatures at both high latitudes and when swimming below the thermocline (Carey et al. 1971; Carey 1982b; Holland et al. 1992; Block et al. 1998; Brill et al. 1999; Marcinek et al. 2001). Based on effects of temperature on RM contractile properties (Johnston and Brill 1984; Altringham and Block 1997) and on aerobic enzyme activities (Dickson 1996), maintaining an elevated $\mathrm{T}_{\mathrm{RM}}$ should enhance or at least stabilize RM aerobic performance and sustainable swimming when tunas are in cool water. Measurements in tunas and closely related ectothermic fishes using swimming-tunnel respirometers have failed to document significant interspecific differences in maximum 
sustainable swimming speeds, but have shown that tunas have higher standard metabolic rates (Sepulveda and Dickson 2000; Sepulveda et al. 2003; Blank et al 2007a, b). By contrast, a recent compilation of tracking data from a wide range of endothermic and ectothermic vertebrates (Watanabe et al. 2015) showed that routine cruising speeds and maximum annual migration ranges in fishes with RM endothermy are two to three times greater than those of the ectothermic fishes included in the study, suggesting a benefit of RM endothermy. Watanabe et al. (2015) also found that the total cost of transport in the endothermic fishes is twice that of ectothermic fishes, which is in agreement with the higher metabolic rates in endothermic fishes measured under laboratory conditions and the previous characterization of tunas as "energy speculators" (Brill and Bushnell 1991a; Brill 1996).

The ability not only to elevate $\mathrm{T}_{\mathrm{RM}}$, but also to control rates of heat transfer with the environment, would be expected to be especially beneficial to Group 3 species that spend more time in cooler waters. Evidence for physiological thermoregulation, presumably by modulating blood flow patterns to the RM to adjust efficiency of heat exchange, and by varying aerobic swimming speed to alter rates of heat production, has been obtained for several tuna species (Holland et al. 1992; Dewar et al. 1994). Physiological control of heat transfer has been measured in juvenile skipjack, yellowfin, and albacore tunas held under conditions in which $\mathrm{T}_{\mathrm{a}}$ could be altered (Stevens et al. 1974; Dizon and Brill 1979a, b; Graham and Dickson 1981; Brill et al. 1994; Dewar et al. 1994). Archival tag studies on free-swimming bigeye tuna (Group 3), recording both water temperature and muscle or peritoneal temperature, indicate that whole-body thermal balance is adjusted during vertical oscillations between the surface water and the water below the thermocline (Holland et al. 1992; Holland and Sibert 1994; Malte et al. 2007; Figure $4 \mathrm{~b}, 6 \mathrm{a})$. Bigeye tunas use physiological mechanisms to reduce heat loss to the environment as they descend to cool waters and absorb heat during ascents when water temperature exceeds tissue temperatures. In southern bluefin tuna, a potential behavioral mechanism to absorb heat was observed when individuals exposed both dorsal and ventral surfaces of their body to the warm ocean-air interface (Gunn and Block 2001). There is also evidence that tunas can use behavioral and physiological mechanisms to increase rates of heat loss. For example, when swimming yellowfin and skipjack tunas were exposed to unusually warm water $\left(30-32^{\circ} \mathrm{C}\right)$, the physiological mechanisms involved in heat transfer apparently shifted modes, from heat retention to heat loss to the environment, presumably in an attempt to avoid overheating (Dizon 
and Brill 1979a, b; Dewar et al. 1994). Similarly, the frequent, short-lived, non-feeding-related forays below the thermocline by free-swimming Pacific bluefin tuna (Thunnus orientalis) may be a mechanism to transfer more heat to the water and thus reduce $T_{R M}$ (Kitagawa et al. 2006).

Bluefin, albacore, and bigeye tunas, the species that lack a central vascular heat exchanger (Collette et al. 2001), should have a greater ability than other tuna species to control $\mathrm{T}_{\mathrm{RM}}$ physiologically. Their circulatory anatomy allows blood flow to the RM via two routes, one with lateral vascular heat exchangers (i.e., lateral circulation) and one without (i.e., dorsal aorta), thus providing a mechanism by which convective heat transfer between the RM and ambient water may be controlled (Graham and Dickson 2001). This potential capacity for physiological thermoregulation, along with regional endothermy, makes these tuna species less dependent upon environmental temperatures and behavioral thermoregulation to maintain locomotor muscle temperatures within functional ranges. It is possible that the upper and lower thermal limits of tuna distributions occur when the $T_{R M}$ reaches a value that is above or below a threshold value at which muscle contractile mechanics are negatively affected. For example, tracking data for freeswimming bigeye tuna undergoing a series of repeated descents below the thermocline (to waters as cold as $7^{\circ} \mathrm{C}$ ), showed that when the RM cooled to $17-18^{\circ} \mathrm{C}$ individuals quickly returned to the warm surface layer, presumably to re-warm the RM (Holland et al. 1992; Figure 6a). Effects of temperature on contraction mechanics of isolated RM fibers have been investigated in kawakawa (Euthynnus affinis), skipjack and yellowfin tunas (Johnston and Brill 1984; Altringham and Block 1997), but not in any Group 3 tunas. Thus, the idea that temperature effects on muscle function limit the latitudinal and depth distributions of tunas and determine interspecific differences in movement patterns cannot be adequately tested at this time. It may be that, when compared to tuna species in Groups 1 and 2, the red muscle of Group 3 tunas has a greater thermal range for optimal function as a result of acclimatization during migration to high latitudes (in species such as Atlantic bluefin tuna) or the alteration of intrinsic muscle properties such a calcium cycling, as has been investigated in the cardiac muscle (Shiels et al. 1999, 2011; Landeira-Fernandez et al. 2004; Galli et al. 2009a, b). Alternatively, Group 3 tunas may be able to maintain $\mathrm{T}_{\mathrm{RM}}$ within the range for optimal muscle function over a wider range of environmental temperature using thermoregulatory mechanisms (Figure 6b) and because they can also elevate visceral temperatures (Carey and Lawson 1973; Carey et al. 1984; Fudge et al. 1997). A greater degree of regional endothermy may allow Group 3 tunas to increase the 
frequency of vertical movements and reduce surface residency intervals, which may extend their absolute time at depth and thus increase the probability of encountering prey without compromising locomotor muscle function while in the deep and cold water. On the other hand, the effects of temperature on the heart (which is maintained at ambient temperature) may be more important in limiting time in cold waters (Brill 1987; Brill et al. 1999; Blank et al. 2004; Shiels et al. 2015). More information on interspecific differences in these physiological characteristics and how they are affected by temperature is needed.

The capacity for RM endothermy develops ontogenetically in tunas (Funakoshi et al. 1985; Dickson 1994; Dickson et al. 2000; Kubo et al. 2008). In most tuna species, small juveniles appear to be limited to warm waters and may avoid incursions into colder waters at depth or higher latitudes until they have developed sufficient capacity to maintain elevated tissue temperatures. For example, during the first year of life, southern bluefin tuna move with the Leeuwin Current from warm-water spawning grounds to more productive waters at higher latitudes off Western Australia, and analysis of otolith stable isotope composition indicates a reduction of $8-10^{\circ} \mathrm{C}$ in temperature during that period (Shiao et al. 2009; Muhling et al. 2017; Hobday et al. 2017). Pacific bluefin tuna remain in warm coastal waters near the main spawning grounds in the East China Sea and Sea of Japan until their first or second year when they move into cooler waters of the transition zone between the Kuroshio and Oyashio Currents and subsequently migrate to the eastern Pacific Ocean (reviewed in Fujioka et al. 2017). It was recently shown that Pacific bluefin juveniles experience a dietary shift to more active prey at a size of $25-35 \mathrm{~cm}$ fork length, which was hypothesized to be related to the development of better capacities for endothermy and swimming (Kitagawa and Fujioka 2017). Similarly, in Hawaii, juvenile yellowfin tuna larger than $1.5 \mathrm{~kg}$ shifted from surface-oriented prey to deep-water shrimp, implying that yellowfin tuna of that size or greater have a wider depth range as a result of having developed sufficient capacity to produce and retain metabolic heat (Graham et al. 2007). The ability of skipjack, as well as yellowfin tunas, when larger than $\sim 1-2 \mathrm{~kg}$, to undertake more extensive vertical excursions characteristic of Group 2 species (Schaefer and Fuller 2007; Schaefer et al. 2009) may be explained by several size-related effects: greater mass of RM to generate heat during swimming, the development of larger and more effective heat exchangers, greater thermal inertia, and greater absolute swimming velocity. Unfortunately little is known about the development of endothermy in the cold-water Group 3 tunas (i.e., Thunnus spp.) as 
their distribution expands from either the tropics to higher latitudes (as in bluefin tunas) or into deeper water (bigeye tuna). It remains unknown whether such migrations are causally associated with the development of the capacity for endothermy, if short-duration excursions into cooler water may stimulate the development of heat production and heat conservation mechanisms in juvenile tunas, or if diet may somehow influence the development of endothermy.

\section{Digestion and visceral endothermy}

The presence of visceral vascular heat exchangers, and thus the capacity to elevate visceral temperatures $\left(T_{v}\right)$ above ambient temperature, occurs only in tuna species that inhabit the coldest waters (i.e., Atlantic, Pacific and southern bluefin, albacore, and bigeye tunas; Carey and Lawson 1973; Carey et al. 1984; Fudge et al. 1997; Bernal et al. 2001) (Figure 7). These species possess variable numbers of visceral retia along the coeliac-mesenteric artery, allowing for conservation of heat produced post-feeding within the entire visceral mass, with the exception of the distal regions of the liver and the gonads that are not perfused via a rete (Kishinouye 1923; Gibbs and Collette 1967; Carey et al. 1984; Fudge and Stevens 2005; Whitlock et al. 2013). Digestive processes within the cecal mass are likely to be the primary heat source for visceral endothermy (Carey et al. 1984; Stevens and McLeese 1984). An elevated $T_{v}$ is a potential mechanism to enhance rates of digestion and assimilation, which would reduce gut clearance times, decrease the interval between feeding events, and allow higher feeding rates, especially in areas of high productivity, and thus increase somatic and gonadal growth rates (Dickson 1995; Brill 1996; Whitlock et al. 2013). When compared to RM endothermy, visceral endothermy results in warming of a greater percentage of body mass and thus may allow tunas that have evolved this trait to spend more time in cold waters before tissue temperatures reach a critical value requiring behavioral thermoregulation (Holland et al. 1992; Dickson and Graham 2004) (see Figure 7).

Free-swimming Atlantic bluefin tuna have been observed to maintain a nearly constant difference $\left(6^{\circ} \mathrm{C}\right)$ between $T_{v}$ and $T_{a}\left(T_{v}-T_{a}=T_{x}\right.$, or excess temperature) until a feeding event, after which $\mathrm{T}_{\mathrm{x}}$ increased to as much as $20^{\circ} \mathrm{C}$ above $\mathrm{T}_{\mathrm{a}}$, followed by a steady decline back to the pre-feeding temperature over the next 20-30 h (Carey and Lawson 1973; Carey et al. 1984; Stevens and McLeese 1984). The onset and offset of this temperature increase suggest that heat production results from increased aerobic metabolism associated with digestion and assimilation 
(the heat increment of feeding). In free-swimming southern bluefin tuna implanted with data loggers to record $\mathrm{T}_{\mathrm{v}}$, consuming a cold meal (sardines) reduced $\mathrm{T}_{\mathrm{v}}$ by approximately $2^{\circ} \mathrm{C}$ during times when ambient temperature remained nearly constant (i.e., $18-19^{\circ} \mathrm{C}$ ), and that decrease was promptly followed by an increase of $0.5-2.6^{\circ} \mathrm{C} \mathrm{h}^{-1}$ to a maximum $\mathrm{T}_{\mathrm{v}}$ of $23.3^{\circ} \mathrm{C}$ as the meal was processed (Clark et al. 2008b). Similar increases in $T_{\mathrm{v}}$ have been measured in Pacific bluefin tuna (Clark et al. 2013; Whitlock et al. 2013). $\mathrm{T}_{\mathrm{v}}$ "spikes" in archival tag data have been used to estimate mean feeding frequencies in free-ranging Pacific and southern bluefin tunas of between 0.89 and 1.8 feeding events per day (Gunn and Block 2001; Kitagawa et al. 2004; Bestley et al. 2008; Whitlock et al. 2013). The feeding frequencies of other tunas remain unknown. It is also unknown whether there is a direct link between vertical excursions and feeding for the larger skipjack and yellowfin tunas that are capable of descending below the thermocline, or for bigeye tuna which undergo regular vertical excursion below the thermocline when they are not associated with fish-aggregating devices (FADs). Nevertheless, in the Thunnus species with visceral retia, the measured feeding frequencies and durations of post-feeding elevation of $T_{v}$ suggest that $T_{v}$ is maintained above $T_{a}$ most of the time (Figure 7), which may contribute to thermal niche expansion. It remains unknown, however, whether the ability to elevate $T_{v}$ is a causative factor in broadening the thermal range of Group 3 tunas.

\section{Cranial endothermy}

All tuna genera have the capacity to elevate the temperature of the cranial region (eyes and brain) above $T_{a}$ (reviewed in Bushnell et al. 1992; Dickson and Graham 2004; Sepulveda et 412 al. 2007), but the degree of cranial endothermy (the $T_{x}$ of the cranial region) varies among tuna 413 species and with $T_{a}$ (Figure 8). For example, within the surface layer of the tropical ocean, the 414 eye and brain temperature of Atlantic bluefin tuna may exceed $\mathrm{T}_{\mathrm{a}}$ only by several degrees, 415 whereas at depth or at high latitudes it may be elevated by as much as $18^{\circ} \mathrm{C}$ above $\mathrm{T}_{\mathrm{a}}$ (Linthicum and Carey 1972; Figure 8). Cranial endothermy has also been documented in billfishes, lamnid sharks, and the opah (Lampris guttatus), suggesting a similar selective pressure related to this trait among epipelagic fishes that make extensive vertical movements (reviewed in Runcie et al. 2009). The mechanisms for heat production and retention vary among the different fish groups that have evolved cranial endothermy. For example, in billfishes, one of the six extra-ocular muscles of each eye, the superior rectus, is modified into a thermogenic tissue (Carey 1982a; 
Block 1991), and the proximal region of the lateral rectus muscle of the opah has an elevated capacity for heat generation (Runcie et al. 2009). In tunas, however, there are few anatomical studies on the metabolic heat source and heat retention mechanisms. In the basal slender tuna, the four pairs of rectus extra-ocular muscles are modified as a potential thermogenic tissue, but there is no evidence of modification of the extra-ocular muscles as a heat source for cranial endothermy in other tunas (Sepulveda et al. 2007; Figure 8). The ocular muscles of skipjack, yellowfin, and Pacific bluefin tunas have similar citrate synthase activities (i.e., capacity for aerobic heat production) and relative muscle masses (i.e., amount of tissue potentially involved in heat production) as do those of the ectothermic scombrids eastern Pacific bonito (Sarda chiliensis) and Pacific chub mackerel (Scomber japonicus) (Holtz 2013). A pair of orbital retia that arise from the internal carotid arteries has been described in several tuna species; this vascular modification would allow the arterial blood entering the orbital retia to be warmed on its way to the brain and eyes via counter-current heat exchange (Linthicum and Carey 1972; Bernal et al. 2001; Sepulveda et al. 2007).

To date, all eye and brain temperature measurements from tunas used to assess the degree of cranial endothermy (Figure 8) have been collected invasively by inserting a temperature sensor into the cranial region of individuals that have been captured and brought on board a vessel. Because there are no studies of cranial endothermy in free-swimming tunas, we do not know the exact capacity tunas may have to modulate cranial temperatures. Furthermore, we have only a partial picture of how the specializations and capacity for cranial endothermy vary interspecifically or affect the vertical and latitudinal distributions of tunas. Despite our limited knowledge, the potential physiological consequences of cranial endothermy for sensory perception and neural integration are profound. Warming of the brain and eyes should enhance the rate of physiological processes associated with vision and the central nervous system, and maintaining a stable cranial temperature as $T_{a}$ changes during descents below the thermocline would be expected to buffer the central nervous system from rapid temperature changes, maintain sensory and integrative functions, and minimize temperature-induced decreases in cranial blood flow while tunas occupy cold, dark waters at depth (Konishi and Hickman 1964; Linthicum and Carey, 1972; Friedlander et al. 1976; Montgomery and MacDonald 1990; Block 1991; Fritsches et al. 2005; van den Burg et al. 2005; Sepulveda et al. 2007). The capacity for cranial endothermy is therefore expected to be the most developed in the Group 3 tuna species. 


\section{Sensory perception}

Sensory studies generally require access to live animals in a controlled laboratory setting, usually with large and expensive holding systems (Nakamura 1972). The nature of tunas (i.e., large, pelagic, obligate ram-ventilating, highly aerobic) makes them inherently difficult to capture, transport, and maintain in good condition at shoreside tanks and requires large holding facilities. Because tunas are difficult and expensive to acquire and to maintain in captivity, they are routinely kept in only a few laboratories (Farwell 2001; Margulies et al. 2013). As a result, their sensory abilities are much less studied than those of freshwater or inshore species. During the last several decades, however, it has become more critical to understand the sensory biology of pelagic fishes due to the effects of environmental conditions on gear vulnerability and the resultant catch per unit effort data upon which population assessments are built (e.g., Mejuto et al. 2005); as well as the need to develop effective strategies to reduce the capture of non-target species or undersized individuals (e.g., Southwood et al. 2008). Here we focus on vision, because anatomical, functional, and behavioral studies show that vision is a critically important sense for tunas (Magnuson 1963; Nakamura 1968; Kawamura et al. 1981a, b; Somiya et al. 2000; Torisawa et al. 2015).

\section{Vision}

Tunas have large eyes which may, in the optically clear aquatic habitat of the open ocean, have horizontal detection ranges of up to $40 \mathrm{~m}$ in brightly-lit surface waters (Clarke and Denton 1962; Jerlov 1976; Morinaga et al. 1993a, b). Sight feeding at depth ( 500 m) in tunas has also been confirmed by their capture on longlines using artificial lures that lack olfactory or gustatory cues (Kawamura et al. 1981b). In addition, there is evidence that tunas visually communicate the presence of prey to other members of the school by using skin chromatophores to effect subtle changes in banding patterns (Strasburg and Marr 1961; Nakamura 1972).

\section{Visual pigments and spectral absorption}

Early measurements of the electrical responses (i.e., electroretinograms, ERGs) to monochromatic light flashes in intact eyes or isolated retinas of tunas demonstrated their peak visual sensitivity to be centered at the blue-green color range (peak absorbancies $\sim 480-505 \mathrm{~nm}$ ), 
where $481 \mathrm{~nm}$ is the wavelength that is transmitted the greatest distance in clear oceanic waters (Tamura et al. 1972; Hanyu et al. 1973; Niwa et al. 1975; Kawamura et al. 1981a, b; Morinaga et al. 1993b). More recent microspectrophotometry (MSP) data (i.e., direct measurement of the wavelengths absorbed by the visual pigments) from adult yellowfin tuna (Group 2 species) show that the predominant visual pigment in rods and cones (i.e., individual dim-light and bright-light retinal photoreceptor cells, respectively) has a maximal absorbance at 483 and $485 \mathrm{~nm}$, respectively (Figure 9a, b) (Loew et al. 2002). Rare cones containing a visual pigment with maximal absorbance centered on a shorter violet wavelength $(426 \mathrm{~nm})$ were also found (Loew et al. 2002). The presence of three visual pigments (with peak absorbancies of 423-436, 473, and $512-515 \mathrm{~nm}$ ) has also been documented using ERG in juvenile Pacific bluefin tuna (Group 3 species) (Matsumoto et al. 2011b). Three visual pigments (436, 488, and $531 \mathrm{~nm}$ ) are also present in istiophorid billfishes (e.g., marlin; reviewed in Bernal et al. 2009), implying a commonality in visual function between tunas and istiophorid billfishes and the ability (albeit limited) to perceive color at least by those species known to spend the majority of their time in brightly-lit surface waters (Holland et al. 1990a, b; Brill et al. 1993; Fritsches et al. 2000, 2003; Kitagawa et al. 2007a; Schaefer et al. 2011; Figure 9a, b).

In contrast, MSP data for species that descend to depths below the brightly-lit surface waters imply that these fishes have visual systems sensitive to a narrower range of wavelengths. The wavelength of maximal absorbance by the visual pigment in cones of bigeye tuna (488-490 $\mathrm{nm}$ ) and of swordfish (495-508 $\mathrm{nm}$ ) suggests that these species have monochromatic vision (i.e., they are "color blind"; Fritsches and Warrant 2004). When not associated with FADs, bigeye tuna spend more time at greater depths $(>400 \mathrm{~m}$ ) during the daytime than do skipjack or yellowfin tunas (Dagorn et al. 2000; Bernal et al. 2009; Schaefer and Fuller 2010; Schaefer et al. 2011; Figures 2, 3, 4), making only occasional forays up to the surface layer to rapidly warm their tissues by absorbing heat from the surrounding water (Holland et al. 1992; Musyl et al. 2003; Malte et al. 2007), but they return to the surface waters during the night. Likewise, swordfish predominantly spend daylight hours below $600 \mathrm{~m}$ and nighttime hours at the surface (Carey and Robinson 1981; Abascal et al. 2010; Sepulveda et al. 2010; Dewar et al. 2011; Evans 512 et al. 2011). Because light is largely monochromatic during the nighttime hours in the surface 513 layer and at depth (Morinaga et al. 1993a), there is no disadvantage to monochromatic vision in 514 these Group 3 species. 
The retinal cell density in the eyes of tunas and istiophorid billfishes is highest in the ventro-temporal region, indicating that the best visual axis in these fishes is up and forward (Tamura and Wisby 1963; Kawamura et al. 1981b; Somiya et al. 2000; Torisawa et al. 2015). This, in turn, suggests that, in brightly-lit surface waters, tunas and istiophorid billfishes attack their prey from below and that their visual systems are tuned to maximize visual contrast of prey silhouetted by down-welling light (i.e., prey are detected as dark objects against a bright background). These data are congruent with the "sensitivity hypothesis," which predicts that to maximize visual perception there should be a match between the down-welling light (e.g., 481 $\mathrm{nm}$ ) and the peak visual sensitivity (Lythgoe 1979; Douglas 2001). It is also plausible, however, that in dim-light conditions (i.e., at night or at depth) tunas and istiophorid billfishes also detect prey by silhouetting them against the moonlight or the bioluminescence produced by common planktonic organisms that is centered at $475 \mathrm{~nm}$ (Widder 2002). Alternatively, tunas may detect bioluminescent prey organisms as point-light sources contrasted against a dark background (Warrant and Locket 2004).

The visual situation is more complicated when additional species-specific movement patterns are taken into account. For example, Pacific and Atlantic bluefin tunas (Group 3 species) occupy both coastal and pelagic waters in which the maximal light transmission is centered at different wavelengths [green $(\sim 510 \mathrm{~nm})$ versus blue $(\sim 480 \mathrm{~nm})$ light, respectively; Figure 9a, b] (Jerlov 1976; Morinaga et al. 1993b; Lutcavage et al. 2000; Douglas 2001; Block et al. 2005; Wilson et al. 2005; Kitagawa et al. 2007a, b). For this reason, the presence of two visual pigments, one of which is offset from the predominant wavelength of light, should maximize visual perception (“contrast hypothesis") under more turbid coastal conditions (Lythgoe 1979), and this effect may better explain the selective advantages conferred by the multiple visual pigments present in at least some Group 3 species (e.g., Pacific bluefin tuna). Clearly, there is much more to learn before we understand the link between interspecific differences in visual pigments and movement patterns in tunas.

\section{$\underline{\text { Light sensitivity }}$}

543 Light intensity levels decrease rapidly with depth as spectral irradiance narrows simultaneously (i.e., available light becomes dim and monochromatic), even in clear oceanic waters (Morinaga et al. 1993a; Warrant 2004; Figure 9a, b). Dim-light conditions are well known 
to reduce the ability of fishes, including tunas, to detect and capture prey and to maintain school integrity (e.g., Hunter 1968; Glass et al. 1986; Torisawa et al. 2007a).

To date there are few data on the light sensitivity of tunas, with most work having been conducted on Pacific bluefin tuna, an important aquaculture species (Sawada et al. 2005;

Torisawa et al. 2015). This Group 3 species has been documented to make frequent (albeit brief) non-feeding-related forays below $300 \mathrm{~m}$ during the day (Kitagawa et al. 2006, 2007a, b). Based on light levels required for schooling behavior, the optomotor reaction (the ability for eye movements to follow moving strips), and the ERG responses to various light levels, Pacific bluefin tuna appear to have poorer low-light vision than do other marine fishes (Ishibashi et al. 2009; Matsumoto et al. 2009, 2011a; Torisawa et al. 2011, 2015). It is possible that the visual limitations of this species to low light precludes their vertical movements from being preydriven, but rather their vertical movements may be a mechanism to avoid overheating (Kitagawa et al. 2006). Similarly, feeding in southern bluefin tuna mostly occurs throughout the day, with the highest feeding frequency occurring around dawn, with rare feeding events at night associated with a full moon (Bestley et al. 2008).

In contrast, the vertical movement patterns of bigeye tuna give an a priori reason to expect that this Group 3 species would have a visual system that can function well at low light levels. Although sparse, anatomical data support this prediction; for example, large eyes are commonly associated with enhanced vision in low light because they accommodate larger numbers of photoreceptor cells per solid angle of image space (Motani et al. 1999; Fritsches et al. 2003; Pope et al. 2010). The bigeye tuna has larger eyes than its sister species, yellowfin tuna (Godsil and Byers 1944; Itano 2004); relative to skipjack and yellowfin tunas of similar size, the diameter of the lens in bigeye tuna is two times larger than the former and 1.4 times larger than the latter, allowing more light to be collected (Warrant 2004; Warrant and Locket 2004; Kröger et al. 2009). Of the tuna species studied to date, moreover, only the bigeye tuna has a tapetum lucidum, a guanine layer located behind the retina that serves to increase low-light sensitivity (Somiya et al. 2000). Albacore tuna, another Group 3 species, also has larger eyes than species in Groups 1 and 2, but unfortunately the visual capacities (i.e., light sensitivity) of this species remain unmeasured. Nonetheless, Pacific albacore are usually associated with cooler (i.e., deeper, darker) waters and are known to frequent oceanic fronts (i.e., areas of high primary 
productivity) that tend to have increased turbidity and decreased water clarity (Laurs et al. 1977, 1984).

\section{Summation and speed of vision}

In addition to the anatomical (i.e., optical) adaptations for enhancing low-light sensitivity, spatial and temporal summation may occur (Warrant 1999). In vertebrates, spatial summation is achieved by having a high number of photoreceptor cells (rods and cones) converge (through a network of bipolar cells) on ganglion cells, which eventually carry the visual information to the brain (Hughes 1977). There is, however, the inevitable tradeoff that increased low-light sensitivity achieved through convergence reduces visual acuity (i.e., the ability to distinguish two points as separate, or to distinguish the fine detail of an object) (Pettigrew et al. 1988).

Measurements of retinal cell density in tunas suggest a relatively high visual acuity (Tamura and Wisby 1963; Kawamura et al. 1981b; Torisawa et al. 2007b, 2015), although initial behavioral trials did not support this hypothesis (Nakamura 1968). Using only retinal cell density as a measure would, however, overestimate visual acuity if tunas have high levels of spatial summation, and using behavioral responses may underestimate visual acuity if the test images were presented directly in front of the fish (i.e., projected on a part of the retina that does not have the highest retinal cell density). Understanding visual acuity and the extent of spatial summation in tunas is critical to understanding species-specific vertical movement patterns, feeding effectiveness, and gear vulnerability (Kawamura et al. 1981b), and additional research in this area is clearly needed.

Temporal summation provides a second mechanism for enhanced low-light sensitivity by extending the time over which photons are captured by the visual system (Lythgoe 1979; Warrant 1999). As with spatial summation, there is an inevitable tradeoff because temporal summation reduces the speed of vision. More specifically, eyes with long temporal summation times necessarily have a low flicker fusion frequency (FFF), the highest frequency at which a flashing light appears as individual flashes rather than as a continuous light source. In visual systems with long temporal summation times (i.e., low FFFs), fast moving objects appear blurred, if they are detectable at all - clearly a situation disadvantageous to species hunting fast moving prey (e.g., squid) in water with low light levels. While yellowfin tuna (at $25^{\circ} \mathrm{C}$ ) have a FFF of $60 \mathrm{~Hz}$ (Bullock et al. 1991), which is similar to that of other fishes including other marine 
piscivores (Ali and Muntz 1974; Horodysky et al. 2010), bigeye tuna have a lower FFF (40 Hz), but preliminary ERG data imply a greater low-light sensitivity (Brill et al. 2005). Both findings are congruent with bigeye tuna's anatomical adaptations (e.g., large lens, presence of a tapetum lucidum) and reflect the fact that bigeye tuna spend more time at depth during the day than do yellowfin tuna. Incongruously, juvenile Pacific bluefin tuna show both a low FFF $(20 \mathrm{~Hz})$ and poor low-light sensitivity (Matsumoto et al. 2009, 2011a; Torisawa et al. 2015), suggesting that they are restricted to feeding in brightly-lit surface waters (Kitagawa et al. 2006). This may mean that Pacific bluefin tuna are unable to track prey at depth (i.e., at low light levels) and must therefore hunt in well-lit surface waters, resulting in their need to migrate long distances to feed on surface-associated prey in highly productive waters (i.e., upwelling regions). By contrast, bigeye tuna can remain more geographically localized by exploiting the prey at depth by descending with the DSL during the day and following it to shallower waters at night (Musyl et al. 2003; Schaefer and Fuller 2005; Holland and Grubbs 2007). It remains unknown, however, whether the monochromatic tuna species lost color vision as a function of their feeding ecology or if color vision is a derived feature of the surface-associated tunas. MSP data for all tuna species, as well as their sister species, the bonitos, will be needed to address this question.

\section{Thermal effects on speed of vision}

The speed of vision (i.e., FFF) is significantly influenced by temperature (Ali and Muntz 1974), and work on isolated retinas from yellowfin and bigeye tunas shows that the fractional change in FFF per $10^{\circ} \mathrm{C}$ change in temperature $\left(\mathrm{Q}_{10}\right)$ is 2.3 and 2.5 , respectively (i.e., for every $10^{\circ} \mathrm{C}$ decrease in temperature FFF decreases by more than half) (Fritsches et al. 2005; Figure 9c). Surprisingly, this thermal effect on FFF in both tunas is similar to that documented in ectothermic fishes (Hanyu and Ali 1964; Ali and Muntz 1974), whereas in swordfish it is much greater $\left(Q_{10}=5.1\right.$; Fritsches et al. 2005; Figure 9c). In swordfish, modifications of the superior rectus extra-ocular muscles allow for the generation of heat at significant rates (Carey 1982a; Block 1991), and cranial temperatures elevated $13^{\circ} \mathrm{C}$ above $\mathrm{T}_{\mathrm{a}}$ were recorded by acoustic telemetry in one individual during deep descents (Carey, 1990). The swordfish can maintain relatively stable cranial temperatures and high FFF when descending into cold water, but it is not known whether this effect also occurs in tunas as a result of cranial endothermy. Because most tunas do not have extra-ocular muscles specialized for thermogenesis, cranial temperatures may 
vary considerably during descents to depths below the thermocline, and a lower $\mathrm{Q}_{10}$ would reduce the rate of change in FFF that occurs as cranial temperature decreases.

We also note, however, that while elevated eye temperatures in tunas would improve FFF, there is an inevitable tradeoff due to the effect of temperature on low-light sensitivity. Minimal detectable light levels are set by the ability of the visual system to distinguish signals arising from light striking the retinal receptor cells (i.e., rods) from endogenous thermal noise. Because of this effect, a $10^{\circ} \mathrm{C}$ increase in temperature can reduce low-light sensitivity by as much as 10-fold (Reilly and Thompson 2007). It therefore appears that Group 3 species are, in some measure, maintaining low light sensitivity during descents at the expense of a reduced speed of vision (i.e., a reduced FFF). Additional research on the effects of temperature on lowlight sensitivity and FFF in various tuna and other pelagic species is also clearly warranted.

\section{Diurnal change in vision}

In many vertebrates there are diel rhythms in visual function that mirror day-night cycles.

These visual adaptations, termed "retinomotor movements," refer to the contraction and expansion of the masking pigments in the retinal epithelial cells accompanied by the simultaneous movements of rods and cones (Ali 1974). Although this circadian rhythmicity is inherent to the retina itself, the timing (onset versus offset) may be entrained by rhythmic changes in light level at dawn and dusk (Kolbinger et al. 1996; Cahill and Hasegawa 1997). The changes in retinal anatomy are accompanied by functional changes (e.g., light sensitivity and FFF) that are easily demonstrated by ERG (Cameron et al. 2008). The rhythmic changes in retinal function are likewise reflected in circadian rhythms in behavior, including feeding activity (e.g., Olla and Marchioni 1968; Ali 1974). The extent of retinomotor movements, although important for understanding visual capabilities, has not been extensively studied across tuna species. Juvenile Pacific bluefin tuna (Group 3 species) do demonstrate rapid (15 min) retinomotor responses following a change in light level (Masuma et al. 2001), which correlates with the effects of changing light levels during school formation (Torisawa et al. 2007a, 2015). The light threshold for inducing retinomotor movements in Pacific bluefin tuna is higher than those in other fish species (Masuma et al. 2001; Torisawa et al. 2007a) and corresponds with the relatively poor low-light sensitivity in this species (Ishibashi et al. 2009; Torisawa et al. 2015). ERG data from yellowfin tuna (Group 2 species) held in constant darkness show that nighttime 
light sensitivity increases approximately 10 times relative to daylight hours (Brill et al. 2005; K. Fritsches and E. Warrant, unpublished results) and demonstrate a strong circadian clock inherent in tuna retinal tissue, as is common in other vertebrates (e.g., Cameron et al. 2008). Reflective of the changes in light sensitivity, the FFF of yellowfin tuna decreases from $60 \mathrm{~Hz}$ during daylight hours to below $30 \mathrm{~Hz}$ at night (Bullock et al. 1991; K. Fritsches and E. Warrant, unpublished). The relationships of retinomotor movement, circadian rhythms in light sensitivity, FFF, and fish behaviors clearly deserve more attention. Because bigeye tuna remain at depth (often below 400 m) when not associated with FADs or seamounts, they exist in almost constant darkness. In contrast to yellowfin tuna, visual function in bigeye tuna does not show a circadian rhythm, but rather their eyes remain in continuous "night-mode" (i.e., they exhibit high light sensitivity and low FFF) (Brill et al. 2005; K. Fritsches and E. Warrant, unpublished results).

It is unlikely, however, that these are genetically fixed (i.e., species-specific) differences. Rather, retinomotor movements in yellowfin tuna are probably entrained by the day-night light level changes they experience in surface waters, whereas those of bigeye tuna are unlikely to be because this species almost continuously occupies low-light environments. Bigeye tuna do, however, adopt vertical movement patterns similar to those of yellowfin tuna when associated with FADs or seamounts, but immediately revert to their typical repeated-diving behavior pattern when they move away (Holland et al. 1990b; Musyl et al. 2003; Schaefer and Fuller 2005). Thus, the retinomotor movements of bigeye tuna can be out of synchrony with the local light cycle when they first arrive at FADs, or immediately after they depart (assuming retinomotor movements become entrained to the day-night light cycle while the fish occupy surface waters). Knowing how quickly retinomotor movements of bigeye tuna entrain and de-entrain to daily light cycles and whether visual function is impaired immediately after bigeye tuna arrive at or depart from FADs is important to understand and predict behaviors, changes in gear vulnerability, and FAD attraction.

Lunar phase has been documented to influence nighttime depth distributions of various tuna species, with fish remaining deeper during the full moon than during the new moon (Schaefer and Fuller 2002; Musyl et al. 2003; Wilson et al. 2005; Bestley et al. 2009; Orbesen et al. 2017). The most probable explanation is that these behaviors mirror the movements of tuna prey organisms associated with the DSL (Josse et al.1998; Schaefer and Fuller 2002), rather than being a function of the tunas' visual abilities. The daily vertical movements of bigeye tuna are 
well known to mirror those of the DSL (e.g., Josse et al. 1998; Dagorn et al. 2000); depending on temperature and light conditions, the DSL organisms descend to 250-500 m during the day (Dagorn et al. 2000; Domokos et al. 2007).

\section{Cardiovascular function}

The heart

Tuna hearts are generally larger (0.3-0.8\% body mass) than those of other active teleosts (e.g., rainbow trout: $0.1 \%$ body mass, ectothermic scombrids: $0.1-0.4 \%$ body mass) (Basile et al. 1976; Farrell 1991). Tuna hearts also have high values of several indices of aerobic metabolic capacity, including citrate synthase activity (Dickson 1995; Blank et al. 2004, Swimmer et al. 2005), mitochondrial oxygen consumption rate (Moyes et al. 1992), and myoglobin content (Giovane et al. 1980). Some tunas also have a highly developed coronary circulation and a large 712 proportion of the ventricle composed of compact myocardium compared with other active fishes 713 (Tota 1978; Brill and Bushnell 1991a; Farrell et al. 1992). For example, the hearts of bigeye tuna 714 (Group 3) have the largest percentage of compact myocardium of any fish species studied to date ( 75\%; Brill and Bushnell, 1991a) which correlates with strong force development (Galli et al., 2009b). Taken together, these cardiac characteristics allow tunas to achieve maximal heart rates above 120 beats per minute (bpm, at $25^{\circ} \mathrm{C}$ ), peak (i.e., systolic) ventricular pressures that are $\sim 50 \%$ greater than in other active teleosts, and maximum cardiac outputs of $\sim 200 \mathrm{ml} \mathrm{min}^{-1} \mathrm{~kg}^{-1}$ in skipjack tuna (Group 1 species) and $\sim 170 \mathrm{ml} \mathrm{min}^{-1} \mathrm{~kg}^{-1}$ in southern bluefin tuna (Group 3 species) (Basile et al. 1976; Tota 1978; Bushnell and Brill 1991a; Bushnell and Jones 1994; Brill and Bushnell 2001; Clark et al. 2008b). The high maximum cardiac output in tunas is driven by a large volume of blood pumped per beat (stroke volumes $\sim 1-2 \mathrm{ml} \mathrm{kg}^{-1}$ ) paired with high maximum heart rates (Bushnell and Brill 1991a; Farrell 1996; Blank et al. 2002, 2004). Despite these impressive maximum cardiac capabilities, recent work on free-swimming southern bluefin tunas in sea pens (Clark et al. 2008b) and Pacific bluefin tunas in large holding tanks (Clark et al. 2013) implanted with heart rate data-logging tags show that routine heart rates are much lower, ranging from 20 to $50 \mathrm{bpm}$ at $\sim 20^{\circ} \mathrm{C}$. Thus, the cardiac performance specializations may be important for providing a wide scope for increasing maximum cardiac function in tunas, rather than to sustain an elevated routine cardiac performance (Brill and Bushnell 1991a). 
Because limited information is available to correlate in vivo cardiac function with vertical distribution among tuna species, our current understanding relies primarily on data from isolated cardiac muscle strip preparations and isolated single atrial and ventricular muscle cells (cardiomyocytes). In vivo cardiac data from free-swimming fish exist only for juvenile Pacific and southern bluefin tunas (Clark et al. 2008b, 2013), and most in situ whole heart data and isolated muscle strip data are from juvenile skipjack, yellowfin, and Pacific bluefin tunas (Keen et al. 1992; Shiels et al. 1999; Blank et al. 2004). Because as tunas grow there appear to be changes in thermal preferences (e.g., juvenile skipjack and yellowfin tuna belonging to Group 1 and larger individuals belonging to Group 2), there is a need to study both a broader size range and the species in Group 3 that routinely occupy colder waters and maintain a greater $\mathrm{T}_{\mathrm{RM}}$ elevation (Carey and Gibson 1983; Blank et al. 2007a, b; Clark et al. 2010; Figures 5). Furthermore, very little is known about the effects of hypoxia, or the combined effects of hypoxia and decreased temperature, on tuna hearts.

\section{Heart function during temperature change}

The tuna heart is located downstream from vascular heat exchangers and thus receives coronary arterial blood from the gills at ambient water temperature (Brill 1987; Brill et al. 1999). Thus, unlike the tissues served by heat exchangers (i.e., RM, eyes, brain, viscera), which are maintained at higher temperatures, the tuna heart is in thermal equilibrium with $T_{a}$ and changes with $\mathrm{T}_{\mathrm{a}}$, yet must supply blood to warmer, metabolically active tissues. It is therefore probable that the thermal sensitivity of the tuna heart is a critical component limiting short-term vertical movements and long-term horizontal (i.e., latitudinal) migrations (Brill 1987; Brill et al. 1999; Blank et al. 2004; Shiels et al. 2015). Indeed, the short, rapid vertical movement behavior of Group 2 and 3 species has been hypothesized to involve cardiac rewarming (Shiels et al. 2015) (Figures 4, 6a) in addition to the rewarming of the RM and viscera discussed above. The myocardium of Pacific bluefin tuna has also been shown to remodel both morphologically and functionally following chronic temperature change [e.g., with thermal acclimation (Galli et al. 2009a; Shiels et al. 2011)], which may occur naturally during latitudinal migrations. These responses suggest that cardiac function is strongly impacted when tuna move between different thermal environments. 
Studies with isolated tuna hearts show that, similar to other teleosts, acute cooling slows heart rate (i.e., results in bradycardia) (Blank et al. 2004; Clark et al. 2013). Although stroke volume in tunas is at the high end for teleosts, it may be relatively fixed (Farrell, 1996; Brill and Bushnell 2001). Thus, any cold-induced reductions in heart rate will also tend to reduce cardiac output (the volume of blood pumped by the ventricle per minute, or heart rate $\mathrm{x}$ stroke volume) because the heart has limited ability to counteract the reduced heart rate with an increase in stroke volume. Consequently, acute thermal effects on heart function during descents below the thermocline may limit the vertical movements of tunas. This is particularly noteworthy because adrenergic stimulation appears to be less effective when the hearts of tunas are rapidly cooled (Galli et al. 2009b; Shiels et al. 2015) suggesting adrenergic stimulation may be less cardioprotective in tunas when compared to other fishes (e.g., salmonids; Graham and Farrell 1989; Shiels et al. 2003). Interestingly, isolated hearts of small (less than $4 \mathrm{~kg}$ ) yellowfin (Group 1), albacore and Pacific bluefin (Group 3) tunas show a similar degree of cold-induced bradycardia, with heart rate declining from $\sim 110 \mathrm{bpm}$ at $25^{\circ} \mathrm{C}$ to $10-15 \mathrm{bpm}$ at $7^{\circ} \mathrm{C}$ (Blank et al. 2004). The hearts of Pacific bluefin differed, however, in that they were able to contract at temperatures as low as $2^{\circ} \mathrm{C}$, a temperature at which the hearts of the other two species failed, suggesting a greater thermal tolerance for cardiac performance in that Group 3 species (Figure 10a). Although ex vivo (i.e., isolated heart) data strongly indicate that tunas may differ in cardiac thermal adaptations that reflect their distributions, there is little known about their in vivo cardiac performance. Moreover, ex vivo data must be interpreted with caution as, for example, a cardiac output of $\sim 14$ $\mathrm{ml} \mathrm{min}{ }^{-1} \mathrm{~kg}^{-1}$ at $2^{\circ} \mathrm{C}$ (recorded ex vivo) in Pacific bluefin (Figure 10a) would be too low to meet the estimated aerobic oxygen demand of active foraging in this species (Blank et al. 2007a, b), even if venous blood oxygen content was reduced to zero (i.e., 100\% oxygen delivery to the working tissues). Nonetheless, the interspecific differences in cardiac thermal sensitivity measured ex vivo may directly affect the vertical and latitudinal range of tunas. Thus, physiological adjustments during acute cooling, and acclimatization of key heart characteristics during chronic cooling, may be necessary to maintain cardiac function in tunas that routinely dive below the thermocline or in those that undergo cold exposure for prolonged periods during migration to high latitudes. 
The thermal sensitivity of the whole heart is mirrored by the temperature sensitivity of contraction in isolated myocardial tissue. In bigeye tuna (Group 3), when the heart is stimulated at a constant frequency at temperatures from $25^{\circ} \mathrm{C}$ to $5^{\circ} \mathrm{C}$, contractile force is maximal at $15^{\circ} \mathrm{C}$ (Galli et al. 2009b). The positive inotropic effects (i.e., increase in force) of cooling from $25^{\circ} \mathrm{C}$ to $15^{\circ} \mathrm{C}$ (at $0.5 \mathrm{~Hz}$ ) may allow cardiac function to be sustained in cooler waters in bigeye tuna, and correlates with the broader thermal range of this species (Brill et al. 1999). By contrast, cooling the isolated myocardial tissue from yellowfin tuna had a more detrimental effect on contractile performance (Galli et al. 2009b), which may reflect the more limited vertical movements of this species.

In many teleost species, adrenergic stimulation is known to ameliorate the depressive effect of reduced temperature on cardiac function (e.g., Graham and Farrell 1989; Keen et al. 1992). Independent of temperature, adrenergic stimulation (in the $\mathrm{nM}-\mu \mathrm{M}$ range) in atrial muscle preparations from skipjack and yellowfin tunas increases contractile force (Keen et al. 1992; Shiels et al. 1999), a similar scenario that has been documented in ventricle muscle preparations from yellowfin and bigeye tunas (Galli et al. 2009b), but has marginal effects on power output of whole hearts isolated from yellowfin tuna (Blank et al. 2002). When compared at any given temperature, the addition of $1 \mu \mathrm{M}$ adrenaline elevated ventricular contractile force more in bigeye tuna ( $\sim 330 \%$ increase) than in yellowfin tuna ( $190 \%$ increase) (Galli et al. 2009b). This finding suggests that bigeye hearts are more sensitive to adrenaline and that adrenergic stimulation may be an important mechanism for maintaining cardiac force. As discussed above, the efficacy of adrenaline in stimulating contractile force was reduced at cooler temperatures (below $15^{\circ} \mathrm{C}$ ) in both bigeye and yellowfin tunas (Shiels et al. 1999; Galli et al. 2009b), which is opposite to the effect in salmonids in which adrenergic sensitivity is greater at acutely cooler temperatures (Keen et al., 1993; Shiels et al. 2003). Thus, the utility of this mechanism for modulating cardiac function in Group 2 and 3 tunas when in cold, deep waters may be limited. The multitude of physiologically relevant changes that the tuna heart experiences during descent below the thermocline has not been investigated in a systematic way, although initial investigations on myocytes from Pacific bluefin tuna highlight the complexity of the situation at a subcellular, mechanistic level (Shiels et al. 2015). Clearly, future work measuring the contractile response of cardiac muscle to the interactive effects of temperature, adrenaline, and hypoxia, as well as measuring cardiac frequency in species with wide a versus narrow 
vertical distribution, is needed to better understand the physiological adaptations and limitations of tunas.

\section{Temperature and tuna cardiac myocyte function}

Cardiac function is underpinned by the function of the atrial and ventricular cardiomyocytes that make up the contractile chambers of the heart. In general, the morphology of the cardiomyocytes of tunas is similar to that of other fishes, being long $(100-150 \mu \mathrm{m})$ and thin $(3-20 \mu \mathrm{m})$ (Shiels et al. 2004; Di Maio and Block 2008), and there do not appear to be differences in myocyte morphology between similarly sized tunas in Groups 1, 2, and 3 (Shiels, and Brill, unpublished observations).

Many studies have tried to identify cellular specializations in excitation-contraction (EC) coupling that allow for the robust maximal in vivo cardiac performance of tunas. EC coupling is the physiological process responsible for cellular contraction and relaxation and is achieved via the transient rise and fall in intracellular $\mathrm{Ca}^{2+}$ in response to membrane excitation (reviewed in Vornanen et al. 2002). Tunas possess cellular specializations that enhance both the rate and magnitude of $\mathrm{Ca}^{2+}$ cycling (Keen et al. 1992; Shiels et al. 1999; Landeira-Fernandez et al. 2004; Castilho et al. 2007; Di Maio and Block 2008; Galli et al. 2009a, b; Shiels et al., 2011), including increased reliance on the intracellular $\mathrm{Ca}^{2+}$ stores of the sarcoplasmic reticulum (SR) (Shiels and Sitsapesan 2015). Temperature affects all biochemical and biophysical processes in the myocyte, including the function of ion channels and pumps that are responsible for cycling $\mathrm{Ca}^{2+}$ during EC coupling. In teleosts, temperature effects are apparent for the L-type $\mathrm{Ca}^{2+}$ channel (Shiels et al. 2000, 2003), the ryanodine receptor (SR Ca ${ }^{2+}$-release channel) (e.g., Hove-Madsen et al. 2001; Shiels et al. 2002), the SR Ca ${ }^{2+}$ ATPase (SERCA pump) (Shiels et al. 2002; Landeira-Fernandez et al. 2004; Castilho et al. 2007; Di Maio and Block 2008), and the $\mathrm{Na}^{+}-\mathrm{Ca}^{2+}$ exchanger (NCX) (Hove-Madsen et al., 2000; Llach et al. 2001; Marshall et al. 2002).

The action potential (AP) that initiates EC coupling, measured from the surface of isolated yellowfin tuna hearts using monophasic action potential recordings (Patrick et al. 2011) and in single isolated Pacific bluefin tuna myocytes (Galli et al. 2009a; Shiels et al. 2015), was found to be broadly the same as that of other teleost species (Haverinen and Vornanen 2009). The AP duration in Pacific bluefin tuna is highly sensitive to acute temperature changes (Galli et al. 2009a; Shiels et al. 2015) and appears to be less affected by thermal acclimation than it in 
freshwater teleost hearts. Indeed, Galli et al. (2009a) hypothesized that the Pacific bluefin heart does not become refractory (i.e., it will still be responsive to a new AP stimulation) in the cold, despite prolongation of the AP, because the basal duration is shorter than that of other species. Although this hypothesis remains to be tested, it may explain how bluefin tunas (Group 3) are able to prevent cardiac refractoriness when cooling prolongs AP duration as they move into cold waters in search of prey.

There are two main sources of $\mathrm{Ca}^{2+}$ that power myocardial contraction in teleosts. The first is $\mathrm{Ca}^{2+}$ influx across the sarcolemmal membrane of cardiac myocytes through the L-type $\mathrm{Ca}^{2+}$ channel (Keen et al. 1992; Shiels and Farrell 1997; Vornanen et al. 2002; Shiels et al. 2006), and the second source for $\mathrm{Ca}^{2+}$ is the intracellular stores of the SR. There is no evidence to support differences in L-Type $\mathrm{Ca}^{2+}$ channel current underlying differences in vertical mobility among tunas, but data are limited. Work on the closely related ectothermic scombrids (Scomber japonicus and Sarda chiliensis) showed that the $\mathrm{Ca}^{2+}$ current amplitude is lower in these species compared to tunas (Shiels et al. 2004; Galli et al. 2011). In addition, while acute cooling decreased peak current amplitude in both yellowfin (larger than $4 \mathrm{~kg}$; Group 2) and Pacific bluefin (Group 3) tunas, the total $\mathrm{Ca}^{2+}$ carried by the L-type $\mathrm{Ca}^{2+}$ channel was inhibited more significantly by the cold in the Pacific bluefin, due to differing kinetics. This could be explained if this species relies more on intracellular $\mathrm{Ca}^{2+}$ stores released from the SR. That hypothesized interspecific difference is supported by finding that the $\mathrm{SR} \mathrm{Ca}^{2+}$ stores in Pacific bluefin tuna (Group 3) myocytes are significantly greater than those of the yellowfin tuna (Group 2) (Galli et al. 2011). Relatively little is known, however, about this aspect of EC coupling in the myocardium of other tuna species.

\section{Role of the sarcoplasmic reticulum (SR)}

In Group 3 tuna species, which tolerate cold temperatures, myocardial contraction appears to be more dependent on SR $\mathrm{Ca}^{2+}$ stores (Galli et al. 2011; Shiels et al. 2011). This is not surprising given that increased SR $\mathrm{Ca}^{2+}$ cycling is a hallmark of thermal tolerance in hibernating endotherms (Wang et al. 1997), suggesting a common mechanism for cold tolerance across vertebrates. Recent work has also demonstrated that Pacific bluefin tuna are able to increase the SR complement and $\mathrm{SR} \mathrm{Ca}^{2+}$ utilization in response to chronic cold (Shiels et al. 2011). Although there are no similar cellular data for bigeye tuna, isolated ventricular myocardium from 
bigeye tuna showed a greater reduction in developed force $(30 \%)$ when $\mathrm{Ca}^{2+}$ contribution from the SR was inhibited than did ventricular myocardium from yellowfin tuna (6\%) (Galli et al. 2009b). A potential mechanism to increase $\mathrm{SR} \mathrm{Ca}^{2+}$ content in the cold is via upregulation of the $\mathrm{Ca}^{2+}$-ATPase pump (SERCA), which moves cytosolic $\mathrm{Ca}^{2+}$ into the SR during relaxation. Biochemical studies with isolated SR vesicles clearly show that, at comparable temperatures, SERCA activity is greater in Pacific bluefin tuna myocardium compared with other tuna species and other scombrids (Landeira-Fernandez et al. 2012) (Figure 10b). In addition, the myocardium of Pacific bluefin tuna has both a more extensive SR and a higher amount of SERCA than that of yellowfin and albacore tunas and Pacific chub mackerel (Landeira-Fernandez et al. 2004;

Castilho et al. 2007; Di Maio and Block 2008). The extensive SR development in the myocardium of Pacific bluefin tuna may allow this species to recruit additional SR-derived $\mathrm{Ca}^{2+}$ and maintain cardiac contractility in cold waters (Shiels and Sitsapesan, 2015). The SR complement can, moreover, be increased by remodeling processes that occur during cold acclimation (> 4 weeks) to provide stronger and faster contraction (Shiels et al. 2011), resembling the changes that occur in temperate freshwater perch (Bowler and Tiiri 1990) and hibernating mammals (Wang et al. 1997). The ability to recruit the intracellular $\mathrm{SR} \mathrm{Ca}^{2+}$ stores when descending below the thermocline or migrating latitudinally into cold water, is probably an important factor in maintaining heart function.

The role of other cellular processes and components of $\mathrm{Ca}^{2+}$ cycling (including the sarcolemmal sodium-calcium exchanger ( $\mathrm{NCX}$ ), the ryanodine receptor, and $\mathrm{Ca}^{2+}$ buffering) have yet to be directly investigated in any tuna myocardium.

\section{Integrative cardiac responses to a changing ambient environment}

Due to the inherent difficulties in measuring cardiac function in free-swimming, unrestrained tunas, very little is known about the integrative cardiac response to changes in ambient water conditions. Recently, Clark and colleagues (Clark et al. 2008b, 2013) have employed archival tag technology to understand how heart rate is altered by decreases in temperature in swimming tuna. Their work shows routine heart rates of $\sim 40 \mathrm{bpm}$ at $30^{\circ} \mathrm{C}$, and a cold-induced bradycardia ( $\mathrm{Q}_{10}$ of $\sim 2.7$ ) as temperature decreases to $15^{\circ} \mathrm{C}$. These findings support a direct effect of temperature on tuna cardiac function and suggest that bradycardia would occur during descents below the thermocline. It is, however, important to know the extent to which 
stroke volume can change in vivo to understand the influence of cold-induced bradycardia on overall cardiac output. Indeed, a decrease in heart rate could be accompanied by an increase in stroke volume due to longer filling times, which would minimize the decrease in cardiac output, as has been demonstrated in isolated working hearts from Pacific bluefin and yellowfin tunas (Blank et al. 2002, 2004). This inverse relationship between heart rate and stroke volume is, however, observed only when the heart is not working maximally (Blank el at. 2002). At maximal filling pressures, the stroke volume in yellowfin tuna is invariant during a decrease in temperature; thus, a drop in temperature leads to decreased cardiac output (Blank et al. 2002). Clearly, there remain gaps in our understanding of the in vivo scope for stroke volume modulation in tuna, and data of this nature are necessary to reconcile tradeoffs between heart rate and stroke volume in regulating cardiac output.

Recently the interacting effects of temperature, contraction frequency, and adrenergic stimulation were investigated in isolated ventricular myocytes from the Pacific bluefin tuna in an attempt to understand how cardiac contractility could be maintained in vivo during a descent into cool waters when several variables change simultaneously (Shiels et al. 2015). The results showed that action potential duration is prolonged by adrenaline $(500 \mathrm{nM})$ which helps to offset the direct effect of temperature and cardiac frequency on $\mathrm{Ca}^{2+}$ influx (Figure 10c), such that when these stressors were combined in a physiologically realistic way, intracellular $\mathrm{Ca}^{2+}$ levels were fairly consistent during a $20^{\circ} \mathrm{C}$ acute temperature change (Figure 10d). These interacting processes have not been systematically studied in other tuna species. Moreover, the extent to which adrenergic stimulation can rescue the fall in cardiac output at cold temperatures requires additional study because adrenaline is less effective at cooler temperatures in tunas than it is in other fishes (Blank et al. 2002; Galli et al. 2009b; Shiels et al. 2015).

In summary, we are a long way from understanding the interrelations among temperature, cardiac frequency, stroke volume, and inotropic agents, even in a single species of tuna. Work is needed across levels of biological organization, particularly in vivo, to understand the role that cardiac function plays in limiting the movements of tunas and explaining their distributions within the pelagic environment.

\section{Hypoxia tolerance}


There has been a long standing interest in the hypoxia tolerance of tunas because of its importance for defining suitable habitats, mechanistically explaining latitudinal distributions and vertical movement patterns, standardizing fishery catch and effort statistics, and predicting the

effects of climate change on tuna fisheries (e.g., Barkley et al. 1978; Brill 1994; Brill and Lutcavage 2001; Kirby 2001; Bigelow et al. 2002; Bigelow and Maunder 2007; Bestley et al. 2009; Lehodey et al. 2011; Raye and Weng 2015). Initial laboratory work investigating the effects of reduced concentrations of dissolved oxygen (DO) in the ambient water (i.e., hypoxia) on skipjack and yellowfin tunas $\left(\right.$ at $25^{\circ} \mathrm{C}$ ) showed that the former consistently increased swimming speeds at moderate levels of hypoxia (DO of $\sim 3.5 \mathrm{mg} \mathrm{L}^{-1}$ ), presumably to increase ventilation or move away from the hypoxic water, and survived relatively short exposures (less than $1 \mathrm{~h}$ ) to more severe hypoxia (DO below $3 \mathrm{mg} \mathrm{L}^{-1}$ ). In contrast, yellowfin tuna did not increase swimming speed until ambient DO reached lower levels $\left(2.4 \mathrm{mg} \mathrm{L}^{-1}\right)$ and survived exposure to extreme hypoxia (DO $\sim 1.3 \mathrm{mg} \mathrm{L}^{-1}$ ) for over $3 \mathrm{~h}$ (Dizon 1977; Gooding et al. 1981). Taken together, these observations imply that skipjack tuna is less tolerant of hypoxia than yellowfin tuna. Albacore tuna (Group 3) also appear intolerant of hypoxia because their oxygen consumption rate (at $15^{\circ} \mathrm{C}$ ) decreased as DO was reduced from 5.1 to $2.6 \mathrm{mg} \mathrm{L}^{-1}$ (Graham et al. 1989), implying that oxygen delivery to the tissues could not be maintained at these levels of hypoxia. Subsequent laboratory work aimed at understanding the physiological responses of skipjack and yellowfin tunas to hypoxia showed that, in both species, even modest reductions in DO concentration (to $\sim 5.5 \mathrm{mg} \mathrm{L}^{-1}$ at $25^{\circ} \mathrm{C}$ ) induce physiological responses, including increases in ventilation volume and bradycardia (Bushnell et al. 1990; Bushnell and Brill 1991, 1992; Brill 1994; Korsmeyer et al. 1996a). These responses to hypoxia are well documented in fishes and serve to maintain rates of oxygen uptake and delivery to tissues and to protect cardiac function (e.g., Gamperl and Driedzic 2009; Perry et al. 2009). Because tunas appear to have a limited ability to increase stroke volume during hypoxia-induced bradycardia, cardiac output fell with heart rate (Bushnell and Brill 1992; Farrell et al. 1992; Brill and Bushnell 2001; Blank et al. 2002 , 2004). This may be because stroke volume was already maximal under the experimental conditions, although the ability of tunas to increase stroke volume to offset changes in heart rate in vivo remains unknown. Regardless of compensatory change in stroke volume during hypoxic bradycardia, impaired oxygen delivery by the cardio-respiratory system undoubtedly contributes to hypoxia sensitivity in tunas. 
Models of tuna oxygen demand and delivery (based on the laboratory-derived data) were subsequently developed and used to investigate maximum rates of oxygen delivery, maximum sustainable swimming speeds, and times required to recover from exhaustive exercise at various levels of hypoxia (Bushnell and Brill 1991; Brill 1994; Korsmeyer et al. 1996a, b). Yellowfin tuna are predicted to be able to survive in DO concentrations of $3.7 \mathrm{mg} \mathrm{L}^{-1}$, but only at their minimum swimming speeds (i.e., those needed to maintain hydrostatic equilibrium; Magnuson 1973), whereas skipjack tuna cannot survive oxygen levels this low. For skipjack and yellowfin tunas, reductions in DO concentrations to below $74 \%$ saturation $\left(5 \mathrm{mg} \mathrm{O}_{2} \mathrm{~L}^{-1}\right.$, at $\left.25^{\circ} \mathrm{C}\right)$ and $66 \%$ saturation $\left(4.5 \mathrm{mg} \mathrm{O}_{2} \mathrm{~L}^{-1}\right.$, at $\left.25^{\circ} \mathrm{C}\right)$, respectively, are predicted to significantly prolong the time required to recover from exhaustive exercise and to impair the ability to meet metabolic oxygen demands above those needed for swimming (Brill 1994; Bushnell and Jones 1994). These data agree with oxygen limitation on vertical movements of these species observed with acoustic telemetry (Holland et al. 1990b; Cayré and Marsac 1993), but are higher than the DO concentrations that induce a behavioral response in laboratory studies (Dizon 1977).

Acoustic telemetry studies, archival tag records, and depth of capture data from longline fisheries all indicate that bigeye tuna are much more tolerant of hypoxia than are skipjack and yellowfin tunas, and that they routinely occupy depths where DO concentration is below $21 \%$ saturation at $10^{\circ} \mathrm{C}\left(2 \mathrm{mg} \mathrm{O}_{2} \mathrm{~L}^{-1}\right.$ ) (Hanamoto 1987; Holland et al. 1990b; Boggs 1992; Musyl et al. 2003; Evans et al. 2008; Schaefer et al. 2009; Howell et al. 2010; Schaefer and Fuller 2010). Direct laboratory measurements of physiological responses likewise demonstrate a greater tolerance to hypoxia in bigeye tuna compared to skipjack and yellowfin tunas (Bushnell et al. 1990). Larger skipjack and yellowfin tunas occasionally make rapid brief descents below $300 \mathrm{~m}$ in the eastern and central Pacific Ocean, but these species do not occupy those depths for extended periods of time as do bigeye tuna (Schaefer and Fuller 2007; Schaefer et al. 2009, 2011; Howell et al. 2010). Thus, we argue that skipjack and yellowfin tunas cannot survive this level of hypoxia ( $2 \mathrm{mg} \mathrm{O}_{2} \mathrm{~L}^{-1}$ ) for long periods of time, especially given the simultaneous reductions in temperature (to less than $10^{\circ} \mathrm{C}$ ) which would result in reduced heart rate and thereby exacerbate the reduced oxygen delivery by the cardio-respiratory system caused by hypoxia (Korsmeyer et al. 1996a; Blank et al. 2002, 2004). There are, however, no published studies describing the effects of simultaneous reductions in temperature and DO concentration on the functioning of tunas' cardio-respiratory systems, and research to ascertain how and how well 
various tuna species tolerate simultaneous acute reductions in temperature and oxygen are clearly warranted.

\section{Temperature and hypoxia effects on blood hemoglobin-oxygen binding}

As described above, tunas subject themselves to extensive changes in water temperature through their daily vertical and seasonal latitudinal movements (Gunn and Block 2001; Sharp 2001). The binding of oxygen to hemoglobin is an exothermic reaction (i.e., produces heat) and, because added heat (i.e., an increase in temperature) tends to reverse exothermic binding reactions, the tendency of hemoglobin to bind oxygen (i.e., hemoglobin oxygen-binding affinity) is reduced by an increase in temperature (Powers et al. 1979; Weber and Fargo 2004). Tuna blood must retain its functional properties (i.e., the ability extract oxygen from the ventilatory water stream passing over the gills and to deliver it to the tissues) in spite of being subjected to large temperature changes (up to $20^{\circ} \mathrm{C}$ ) that occur over time scales ranging from seconds due to vertical movements, to months due to latitudinal migrations. Tuna blood also experiences rapid changes in temperature as it passes from the gills (which are at ambient temperature) to the tissues (swimming muscle, eyes and brain, and, in some species, the viscera), which are maintained at elevated temperatures. Rossi-Fanelli and Antonini (1960) were the first to describe the unusual temperature independence of oxygen-binding affinity in tuna hemoglobin preparations and ascribed this to the necessity for blood to retain its functional properties over a wide range of temperatures. Subsequent work involving whole blood from several tuna species confirmed this general idea, but also showed the effects of temperature on whole tuna blood oxygen-binding affinity to be species-specific, and reflective of hypoxia tolerance and vertical movement patterns (Cech et al. 1984; Jones et al. 1985; Brill and Bushnell 1991b, 2006; Lowe et al. 2000; Clark et al. 2008a). A recent study (Lilly et al. 2015) demonstrated how blood oxygenbinding affinity is affected by temperature acclimation as would occur during latitudinal migrations in Group 3 tunas.

The effects of temperature on tuna blood oxygen binding and release are complicated by the fact that tuna blood is subjected to both "open-system" and "closed-system" temperature changes. The former refers to the situation occurring in the gills where blood is free to exchange gases and proton equivalents with another medium (in this case, the water passing over the gills) and temperature changes are rapid due to vertical ascents or descents. The latter refers to the 
situation occurring as blood passes through the vascular counter-current heat exchangers and arterial blood temperature increases from that in the gills (i.e., ambient temperature) to that of the warmed tissues but is not able to exchange gases or proton equivalents with another medium (Stevens et al. 1974). During open-system temperature change, blood $\mathrm{O}_{2}$ content remains constant, whereas the partial pressures of oxygen and carbon dioxide $\left(\mathrm{pO}_{2}\right.$ and $\mathrm{pCO}_{2}$, respectively) vary and are thus accompanied by relatively minor changes in plasma $\mathrm{pH}(\mathrm{pHe})$ $\left(\sim 0.004 \Delta \mathrm{pHe} \Delta^{\circ} \mathrm{C}^{-1}\right)$. By contrast, closed-system temperature changes are accompanied by greater change in $\mathrm{pHe}\left(\sim 0.016 \Delta \mathrm{pHe} \Delta^{\circ} \mathrm{C}^{-1}\right)$ and substantial alterations in $\mathrm{pCO}_{2}$ due to changes in $\mathrm{CO}_{2}$ solubility in the plasma and the reciprocal titration of plasma proteins and plasma bicarbonate (Perry et al. 1985; Truchot 1987; Brill et al. 1992).

Fish species that are hypoxia-tolerant have blood with a high oxygen-binding affinity, meaning that the blood has the ability to remove oxygen from the ventilatory water stream even at low ambient oxygen levels (Jensen et al. 1993; Mislan et al. 2016). Not surprisingly, bigeye tuna (Group 3) blood has a higher oxygen-binding affinity than does blood of skipjack (Group 1) and yellowfin (Group 2) tunas (Brill and Bushnell 1991b; Lowe et al. 2000), reflecting the greater tolerance of environmental hypoxia of bigeye tuna. Blood with high oxygen-binding affinity may, however, release less oxygen at active tissues, thereby limiting aerobic metabolic rates, especially in the tissues maintained at elevated temperatures (Yang et al. 1992). Bigeye tuna have surmounted this limitation by having unique blood oxygen-binding characteristics that simultaneously enable this species to be both hypoxia-tolerant and able to maintain high tissue $\mathrm{O}_{2}$ consumption rates (Brill 1996; Lowe et al. 2000). In brief, when the blood of yellowfin, skipjack, and bigeye tunas is compared during similar temperature changes, the latter shows a larger decrease in oxygen-binding affinity when subjected to closed system increases in temperature. As a result, oxygen off-loading in the swimming muscles is not compromised, even though bigeye tuna blood has a high oxygen-binding affinity under the conditions occurring during its passage through the gills. The high oxygen-binding affinity and enhanced response to closed-system temperature changes in bigeye tuna blood thus provides an effective system for extracting oxygen at high rates from the ventilatory water stream even during conditions of low ambient oxygen, while simultaneously ensuring high rates of oxygen delivery and offloading in the muscle capillaries. 
The characteristic of bigeye tuna blood with respect to the effects of closed-system

temperature change on oxygen-binding affinity that provide hypoxia tolerance requires sustained elevated tissue temperatures and may explain bigeye tuna's well documented regular upward excursions into warm surface layers (e.g., Holland et al. 1992; Musyl et al. 2003, 2004; Schaefer and Fuller 2010; Figures 4b, 6a). Because maintenance of a significant difference between ambient temperature and the endothermic tissue temperatures is obligatory for blood oxygen delivery, when tissue temperatures reach $17-18^{\circ} \mathrm{C}$ at depth, bigeye tuna return to warm surface layers to get a "gulp" of heat in a way roughly analogous to the way marine mammals return to the surface to get a "gulp" of air (Holland et al. 1992; Brill et al. 2005; Malte et al. 2007).

Not all Group 3 tunas share with bigeye tuna a higher blood oxygen binding affinity, because they may not be routinely exposed to environmental hypoxia. For example, the blood oxygen-binding affinity of the Atlantic bluefin tuna is similar to that of skipjack, yellowfin, and kawakawa tunas (Jones et al. 1985; Brill and Bushnell 2006), suggesting that this species is as intolerant of hypoxia as are Group 1 and 2 species. This similarity is not unexpected, given the movement patterns of juvenile and adult Atlantic bluefin tunas (Block et al. 2001, 2005; Wilson et al. 2005; Lawson et al. 2010). With the possible exception of spawning areas in the Gulf of Mexico (Teo et al. 2007a, b), this species does not frequent coastal areas with relatively shallow oxygen minimum zones (Garcia et al. 2009; Prince et al. 2010) and would not be expected to encounter hypoxic water to the same extent that bigeye tuna do during their daily vertical movements. By contrast, the blood oxygen affinity of southern bluefin tuna is similar to that of the bigeye tuna (Jones et al. 1985; Lowe et al. 2000; Brill and Bushnell 2006; Clark et al. 2008a), implying that bigeye and southern bluefin tunas share similar tolerances of environmental hypoxia. Southern bluefin tuna can maintain aerobic metabolism at DO concentrations below $\sim 2.5 \mathrm{mg} \mathrm{O}_{2} \mathrm{~L}^{-1}$ (Fitzgibbon et al. 2007, 2010), but it is not known whether southern bluefin are normally exposed to hypoxia. Like Atlantic bluefin tuna, southern bluefin tuna make brief forays to depths below $600 \mathrm{~m}$ (Bestley et al. 2009), but in areas devoid of shallow coastal oxygenminimum zones (Garcia et al. 2009). The presumed hypoxia tolerance of southern bluefin tuna thus lacks an obvious explanation. Pacific bluefin tuna, in contrast, frequent coastal areas of the eastern Pacific (Boustany et al. 2010) with shallow oxygen-minimum zones (Garcia et al. 2009), and the vertical movement patterns of this species most likely exposes individuals to severe 
hypoxia during their dives (Domeier et al. 2004). Unfortunately, the hypoxia tolerance and blood oxygen-binding affinity of Pacific bluefin tuna have not been measured.

\section{Summary}

In this review, we attempt to summarize what is currently known about the physiological characteristics of tunas that we contend are related to tuna distribution, niche expansion, and habitat partitioning within the heterogeneous, three-dimensional oceanic environment. Many characteristics of the pelagic environment, including temperature, dissolved oxygen, pressure, light, and prey abundance, vary with depth and/or latitude, as well as seasonally. Interspecific differences in the physiological tolerance ranges for these environmental variables, alone and in combinations experienced in the field, are associated with the behavior and distribution of the various tuna species. We have focused the discussion on interspecific differences in swimming muscle physiology, visual physiology, and cardiovascular physiology, and on how regional endothermy affects the function of these systems. Tunas share adaptions for continuous and rapid swimming, regional endothermy, and the ability to meet multiple metabolic demands simultaneously (e.g., swim continuously, recover rapidly from exhaustive exercise, and meet the increase in metabolic demand following feeding). The Group 3 tuna species, with the widest ranges both in latitude and depth, are also the species that have evolved visceral endothermy in addition to muscle and cranial endothermy, and thus can maintain more of the core body tissues at temperatures elevated significantly above ambient temperature. These species also have a greater capacity for physiological thermoregulation of muscle temperatures. Although the greater extent of regional endothermy and thermoregulation may be causally related to thermal niche expansion in these tunas, many other factors are involved in the ability of Group 3 tunas to migrate to higher latitudes and especially to descend repeatedly to depths below the thermocline which simultaneously exposes fish to rapid changes in several environmental conditions (temperature, pressure, light level, DO, and prey availability). Although only a limited number of species from each group have been studied in detail, cardiac $\mathrm{Ca}^{2+}$ cycling and cardiac contractility are elevated in the hearts of Group 3 species, which may allow heart function during acute or prolonged forays into cold and sometimes hypoxic waters. The bigeye tuna's hemoglobin has the unusual ability to simultaneously allow oxygen uptake in hypoxic waters and effective delivery of oxygen to warm, active tissues. Thus, adaptations in cardiac characteristics, 
as well as in hemoglobin function, may be critical for niche expansion in these tuna species. As tunas are visual predators, low light sensitivity and increased temporal summation are characteristics associated with vision in Group 3 tunas. Together with cranial endothermy, these features may be important for effective predation in cool, dark and deep waters. Much more remains to be learned, especially in regard to simultaneous changes in multiple environmental variables and whether interspecific differences in integrated physiological performance are causally associated with distribution limits. Future research to understand how and how well different tuna species deal with thermal challenges and hypoxia exposure is needed to understand species-specific movements and distributions, as well as how those may change in the face of changing oceanic conditions, with obvious implications for future tuna fisheries management and resource conservation.

\section{Acknowledgements}

Our review is dedicated with gratitude to all the colleagues, mentors, and students (past, present, and future) who share our curiosity about and passion for high performance pelagic fishes (tunas, billfishes, and sharks). We would like to thank the thoughtful comments and suggestions of the anonymous reviewers of this manuscript, their feedback resulted in marked improvements to this work. We are indebted to T. Tazo, J. Valdez, T. Reposado, S. Malt, and I.P. Ale for logistical support. This material is based in part upon work supported by the National Science Foundation under Grant Number IOS-1354593 to DB. Some work on this publication by KAD was done while serving at and supported by the National Science Foundation. Any opinions, findings, and conclusions or recommendations expressed in this material are those of the author(s) and do not necessarily reflect the views of the National Science Foundation, NOAA, or any of its subagencies. 


\section{References}

Abascal FJ, Mejuto J, Quintans M, Ramos-Cartelle A (2010) Horizontal and vertical movements of swordfish in the southeast Pacific. ICES J Mar Sci 67:466-474

Alexander RM (1993) Buoyancy. In: Evans DH (ed) The Physiology of Fishes. CRC Press, Boca Raton, pp 75-97

Ali MA (1974) Retinomotor responses. In: Ali MA (ed) Vision in Fishes: New Approaches in Research, Volume 1. NATO Advanced Study Institute Series, Plenum Press, New York, pp 313-335

Ali MA, Muntz WRA (1974) Electroretinography as a tool for studying fish vision. In: Ali MA (ed) Vision in Fishes: New Approaches in Research, Volume 1. NATO Advanced Study Institute Series, Plenum Press, New York, pp 159-167

Altringham JD, Block BA (1997) Why do tuna maintain elevated slow muscle temperatures? Power output of muscle isolated from endothermic and ectothermic fish. J Exp Biol 200:26172627

Bannikov, AF (1985) Iskopaemye Skumbrievye SSSR (Fossil Scombrids of the USSR). Nauka, Moscow

Barkley RA, Neill WH, Gooding RM (1978) Skipjack tuna, Katsuwonus pelamis, habitat based on temperature and oxygen requirements. Fish Bull 76:653-662

Basile C, Goldspink G, Modigh M, Tota B (1976) Morphological and biochemical characterisation of the inner and outer ventricular myocardial layers of adult tuna fish (Thunnus thynnus L.). Comp Biochem Physiol 54B:279-83

Berger WH (1981) Paleoceanography: The deep-sea record. In Emiliani CC (ed) The Oceanic Lithosphere. The Sea. Volume 7. John Wiley and Sons, New York, pp 1437-1519

Bernal D (2011) Physiological specializations of different fish groups. Pelagic fishes. In: Farrell AP (ed) Encyclopedia of Fish Physiology: From Genome to Environment. Volume 3. Academic Press, San Diego, pp 1887-1902

Bernal D, Dickson KA, Shadwick RE, Graham JB (2001) Review: Analysis of the evolutionary convergence for high performance swimming in lamnid sharks and tunas. Comp Biochem Physiol 129A:695-726

Bernal D, Sepulveda C, Musyl M, Brill R (2009) The eco-physiology of swimming and movement patterns of tunas, billfishes, and large pelagic sharks. In: Domenici P, Kapoor BG (eds) Fish Locomotion: An Etho-ecological Approach. Science Publishers, Enfield, NH, pp 436-483 
Bestley S, Patterson TA, Hindell MA, Gunn JS (2008) Feeding ecology of wild migratory tunas revealed by archival tag records of visceral warming. J Anim Ecol 77:1323-1333

Bestley S, Gunn JS, Hindell MA (2009) Plasticity in vertical behaviour of migrating juvenile southern bluefin tuna (Thunnus maccoyii) in relation to oceanography of the south Indian Ocean. Fish Oceanogr 18:237-254

Bigelow K, Hampton J, Miyabe N (2002) Application of a habitat-based model to estimate effective longline fishing effort and relative abundance of Pacific bigeye tuna (Thunnus obesus). Fish Oceanogr 11:143-155

Bigelow KA, Maunder MN (2007) Does habitat or depth influence catch rates of pelagic species? Can J Fish Aquat Sci 64:1581-1594

Blank JM, Morrissette JM, Davie PS, Block BA (2002) Effects of temperature, epinephrine and $\mathrm{Ca}^{2+}$ on the hearts of yellowfin tuna (Thunnus albacares). J Exp Biol 205:1881-1888

Blank JM, Morrissette JM, Landeira-Fernandez AM, Blackwell SB, Williams TD, Block BA (2004) In situ cardiac performance of Pacific bluefin tuna hearts in response to acute temperature change. J Exp Biol 207:881-890

Blank JM, Morrissette JM, Farwell, CJ, Price M, Schallert RJ, Block BA (2007a) Temperature effects on metabolic rate of juvenile Pacific bluefin tuna Thunnus orientalis. J Exp Biol 210:4254-4261

Blank JM, Farwell CJ, Morrissette JM, Schallert RJ, Block BA (2007b) Influence of swimming speed on metabolic rates of juvenile Pacific bluefin tuna and yellowfin tuna. Physiol Biochem Zool 80:167-177

Block BA (1991) Endothermy in fish: Thermogenesis ecology and evolution. In: Hochachka PW, Mommsen T (eds) Biochemistry and Molecular Biology of Fishes. Volume 1. Elsevier Scientific Publications, Amsterdam, pp 269-311

Block BA, Dewar H, Williams T, Prince ED, Farwell C, Fudge D (1998) Archival tagging of Atlantic bluefin tuna, Thunnus thynnus. Marine Technol Soc J 32:37-46

Block BA, Dewar H, Blackwell SB, Williams TD, Prince, ED, Farwell CJ, Boustany A, Teo SL, Seitz A, Walli A, Fudge, D (2001) Migratory movements, depth preferences, and thermal biology of Atlantic bluefin tuna. Science 293:1310-1314

Block BA, Finnerty JD, Stewart AFR, Kidd J (1993) Evolution of endothermy in fish: mapping physiological traits on a molecular phylogeny. Science 260:210-214

Block BA, Keen JE, Castillo B, Dewar H, Freund EV, Marcinek DJ, Brill RW, Farwell C (1997) Environmental preferences of yellowfin tuna (Thunnus albacares) at the northern extent of its range. Mar Biol 130:119-132 
Block BA, Teo SL, Walli A, Boustany A, Stokesbury MJ, Farwell, CJ, Weng KC, Dewar H, Williams TD (2005) Electronic tagging and population structure of Atlantic bluefin tuna. Nature 434:1121-1127

Boustany AM, Matteson R, Castleton M, Farwell C, Block BA (2010) Movements of Pacific bluefin tuna (Thunnus orientalis) in the eastern North Pacific revealed with archival tags. Prog Oceanogr 86:94-104

Brill RW (1987) On the standard metabolic rates of tropical tunas, including the effect of body size and acute temperature change. Fish Bull 85:25-35

Brill RW (1994) A review of temperature and $\mathrm{O}_{2}$ tolerance studies of tunas pertinent to fisheries oceanography, movement models and stock assessments. Fish Oceanogr 3:204-216

Brill RW (1996) Selective advantages conferred by the high performance physiology of tunas, billfishes, and dolphin fish. Comp Biochem Physiol 113A:3-15

Brill RW, Bigelow KA, Musyl M, Fritsches KA, Warrant EJ (2005) Bigeye tuna behavior and physiology and their relevance to stock assessments and fishery biology. Coll Vol Sci Pap ICCAT 57(2):142-161

Brill RW, Block BA, Boggs CH, Bigelow, KA, Freund EV, Marcinek DJ (1999) Horizontal movements and depth distribution of large adult yellowfin tuna (Thunnus albacares) near the Hawaiian Islands, recorded using ultrasonic telemetry: Implications for the physiological ecology of pelagic fishes. Mar Biol 133:395-408

Brill RW, Bushnell PG (1991a) Metabolic and cardiac scope of high energy demand teleosts, the tunas. Can J Zool 69:2002-2009

Brill RW, Bushnell PG (1991b) Effects of open and closed system temperature changes on blood-oxygen dissociation curves of skipjack tuna (Katsuwonus pelamis) and yellowfin tuna (Thunnus albacares). Can J Zool 69:1814-1821

Brill RW, Bushnell PG (2001) The cardiovascular system of tunas. In: Block BA, Stevens ED (eds) Fish Physiology, Volume 19. Academic Press, San Diego, pp 79-120

Brill RW, Bushnell PG (2006) Effects of open- and closed-system temperature changes on blood $\mathrm{O}_{2}$-binding characteristics of Atlantic bluefin tuna (Thunnus thynnus). Fish Physiol Biochem 32:283-294

Brill RW, Bushnell PG, Jones DR, Shimazu M (1992) Effects of temperature change, in vivo and in vitro, the on acid-base status of blood from yellowfin tuna (Thunnus albacares). Can J Zool 70:645-662 
Brill RW, Dewar H, Graham JB (1994). Basic concepts relevant to heat transfer in fishes, and their use in measuring the physiological thermoregulatory abilities of tunas. Environ Biology Fish 40:109-124

Brill, RW, Holts DB, Chang RKC, Sullivan S, Dewar H, Carey, FG (1993) Vertical and horizontal movements of striped marlin (Tetrapturus audax) near the main Hawaiian Islands, determined by ultrasonic telemetry, with simultaneous measurement of oceanic currents. Mar Biol 117:567-574

Brill R, Lutcavage M (2001) Understanding environmental influences on movements and depth distribution of tunas and billfish can significantly improve stock assessments. In GR Sedberry (ed) Island in the Stream: Oceanography and Fisheries of the Charleston Bump. American Fisheries Society Symposium 25, Bethesda, MD pp 179-198

Boggs, CH (1992) Depth, capture time, and hooked longevity of longline-caught pelagic fish: Timing bites of fish with chips. Fish Bull 90:643-658.

Bowler K, Tirri R (1990) Temperature dependence of the heart isolated from the cold or warm acclimated perch (Perca fluviatilis). Comp Biochem Physiol 96A:177-180.

Bullock TH, Hofmann MH, New JG, Nahm FK (1991) Dynamic properties of visual evoked potentials in the tectum of cartilaginous and bony fishes, with neuroethological implications. $\mathbf{J}$ Exp Biol Suppl 5:142-155

Bushnell PG, Brill RW (1991) Responses of swimming skipjack (Katsuwonus pelamis) and yellowfin (Thunnus albacares) tunas exposed to acute hypoxia, and a model of their cardiorespiratory function. Physiol Zool 64:787-811

Bushnell PG, Brill RW (1992) Oxygen transport and cardiovascular responses in skipjack tuna (Katsuwonus pelamis) and yellowfin tuna (Thunnus albacares) exposed to acute hypoxia. J Comp Physiol 162B:131-143

Bushnell PG, Brill RW, Bourke RE (1990) Cardiorespiratory responses of skipjack tuna Katsuwonus pelamis, yellowfin tuna, Thunnus albacares, and bigeye tuna, T. obesus, to acute reductions in ambient oxygen. Can J Zool 68:1857-1865

Bushnell PG, Jones DR (1994) Cardiovascular and respiratory physiology of tuna: Adaptations for support of exceptionally high metabolic rates. Environ Biol Fish 40:303-318

Bushnell PG, Jones DR, Farrell AP (1992) The arterial system. In: Hoar WS, Randall DJ (eds) Fish Physiology, Volume 12 (part B). Academic Press, San Diego, pp 89-120

Cahill GM, Hasegawa M (1997) Circadian oscillators in vertebrate retinal photoreceptor cells. Biol Signal 6:191-200 
Cameron MA, Barnard AR, Lucas RJ (2008). The electroretinogram as a method for studying circadian rhythms in the mammalian retina. J Genet 87:459-466

Carey FG (1982a) A brain heater in the swordfish. Science 216:1327-1329

Carey FG (1982b) Warm fish. In: Taylor CR, Johansen K, Bolis L (eds) A Companion to Animal Physiology, 5th International Conference on Comparative Physiology, Sandbjerg, Denmark, Cambridge University Press, Cambridge, UK, pp 216-234

Carey FG 1990 Further observations on the biology of the swordfish. In: Stroud RH (ed) Planning the Future of Billfishes. National Coalition for Marine Conservation Inc., Savannah, Georgia, pp 102-122

Carey FG, Gibson QH (1983) Heat and oxygen exchange in the rete mirable of the bluefin tuna, Thunnus thynnus. Comp Biochem Physiol 74A:333-342

Carey FG, Kanwisher, JW, Stevens ED (1984) Bluefin tuna (Thunnus thynnus) warm their viscera during digestion. J Exp Biol 109:1-20

Carey FG, Lawson KD (1973) Temperature regulation in free swimming bluefin tuna. Comp Biochem Physiol 44A:375-392

Carey FG, Robison BH (1981) Daily patterns in the activities of swordfish (Xiphias gladius) observed by acoustic telemetry. Fish Bull 79:277-292

Carey FG, Teal JM (1966) Heat conservation in tuna fish muscle. Proc Natl Acad Sci USA 56:1464-1469

Carey FG, Teal JM (1969) Regulation of body temperature by the bluefin tuna. Comp Biochem Physiol 28:205-213

Carey FG, Teal JM, Kanwisher JW, Lawson KD, Beckett JS (1971) Warm bodied fish. Amer Zool 11:135-143

Carroll, RL (1988) Vertebrate Paleontology and Evolution. W.H. Freeman and Company, New York.

Castilho PC, Landeira-Fernandez AM, Morrissette J, Block BA (2007) Elevated $\mathrm{Ca}^{2+}$ ATPase (SERCA2) activity in tuna hearts: Comparative aspects of temperature dependence. Comp Biochem Physiol 148A:124-132

Cayré P, Marsac F (1993) Modeling the yellowfin tuna (Thunnus albacares) vertical distributions using sonic tagging results and local environmental parameters. Aquat Living Resour 6:1-14 
Cech JJ, Laurs RM, Graham JB (1984) Temperature-induced changes in blood gas equilibria in the albacore, Thunnus alalunga, a warm-bodied tuna. J Exp Biol 109:21-34

Chow S, Kishino H (1995) Phylogenetic relationships between tuna species of the genus Thunnus (Scomdridae: Teleostei): Inconsistent implications from morphology, nuclear and mitochondrial genomes. J Mol Evol 41:741-748

Chow S, Nakagawa T, Suzuki N, Takeyama H, Matsunaga T (2006). Phylogenetic relationships among Thunnus species inferred from rDNA ITS1 sequence. J Fish Biol 68:24-35

Ciezarek AG, Dunning LT, Jones CS, Noble LR, Humble E, Stefanni S, Savolainen V (2016) Substitutions in the glycogenin-1 gene are associated with the evolution of endothermy in sharks and tunas. Genome Biol Evol 8:3011-3021

Clark TD, Brandt WT, Nogueira J, Rodriguez LE, Price M, Farwell CJ, Block BA (2010) Postprandial metabolism of Pacific bluefin tuna (Thunnus orientalis). J Exp Biol 213:23792385

Clark TD, Farwell CJ, Rodriguez LE, Brandt WT, Block BA (2013) Heart rate responses to temperature in free-swimming Pacific bluefin tuna (Thunnus orientalis). J Exp Biol 216:32083214

Clark TD, Seymour RS, Wells RMG, Frappell PB (2008a) Thermal effects on the blood respiratory properties of southern bluefin tuna, Thunnus maccoyii. Comp Biochem Physiol 150A: 239-246

Clark TD, Taylor BD, Seymour RS, Ellis D, Buchanan J, Fitzgibbon QP, Frappell PB (2008b) Moving with the beat: Heart rate and visceral temperature of free-swimming and feeding bluefin tuna. Proc Roy Soc Ser B-Biol 275: 2841-2850

Clarke GL, Denton, EJ (1962) Light and animal life. In: Hill MN (ed) The Sea. Volume 1. Interscience, London, pp 456-468

Collette BB (1978) Adaptations and systematics of the mackerels and tunas. In: Sharp GD, Dizon AE (eds) The Physiological Ecology of Tunas, Academic Press, San Diego, pp 7-39

Collette BB, Nauen CE (1983) Scombrids of the World: An Annotated and Illustrated Catalogue of Tunas, Mackerels, and Bonitos, and Related Species Known to Date. FAO Species Catalogue. Volume 2. Food and Agriculture Organization of the United Nations, Rome

Collette BB, Reeb C, Block BA (2001) Systematics of the tunas and mackerels (Scombridae). In: Block BA, Stevens ED (eds) Fish Physiology, Volume 19. Academic Press, San Diego, pp 133

Dagorn L, Bach P, Josse E (2000) Movement patterns of large bigeye tuna (Thunnus obesus) in the open ocean, determined using ultrasonic telemetry. Mar Biol 136:361-371 
Deary AL, Moret-Ferguson S, Engels M, Zettler E, Jaroslow G, Sancho G (2015) Influence of Central Pacific oceanographic conditions on the potential vertical habitat of four tropical tuna species. Pac Sci 69:461-475

Dewar H, Graham JB, Brill RW (1994) Studies of tropical tuna swimming performance in a large water tunnel: II. Thermoregulation. J Exp Biol 192:33-44

Dewar H, Prince E, Musyl M, Brill R, Sepulveda C, Lou J, Foley D, Serafy J, Domeier M, Nasby-Lucas N, Snodgrass D, Laurs M, Block B, McNaughton L (2011) Movements and behaviors of swordfish in the Atlantic and Pacific oceans examined using pop-up satellite tags. Fish Oceanogr 20:219-241

Díaz-Arce N, Arrizabalaga H, Muru H, Irigoien X, Rodríguez-Ezpeleta N (2016) RAD-seq derived genome-wide nuclear markers resolve the phylogeny of tunas. Mol Phylogenet Evol 102:202-207

Dickson K (1994) Tunas as small as $207 \mathrm{~mm}$ fork length can elevate muscle temperatures significantly above ambient water temperature. J Exp Biol 190: 79-93

Dickson K (1995) Unique adaptations of the metabolic biochemistry of tunas and billfishes for life in the pelagic environment. Environ Biol Fish 42:65-97

Dickson KA (1996) Locomotor muscle of high-performance fishes: What do comparisons of tunas with ectothermic sister taxa reveal? Comp Biochem Physiol 113A:39v49

Dickson KA, Graham JB (2004) Evolution and consequences of endothermy in fishes. Physiol Biochem Zool 77:998-1018

Dickson KA, Johnson NM, Donley JM, Hoskinson JA, Hansen MW, Tessier JS (2000) Ontogenetic changes in characteristics required for endothermy in juvenile black skipjack tuna (Euthynnus lineatus). J Exp Biol 203:3077-3087

Di Maio A, Block B (2008) Ultrastructure of the sarcoplasmic reticulum in cardiac myocytes from Pacific bluefin tuna. Cell and Tissue Res 334:121-134

Dizon AE (1977) Effect of dissolved oxygen concentration and salinity on swimming speed of two species of tuna. Fish Bull 75:649-653

Dizon AE, Brill RW (1979a) Thermoregulation in yellowfin tuna (Thunnus albacares). Physiol Zool 52:581-593

Dizon AE, Brill RW (1979b) Thermoregulation in tuna. Amer Zool 19:249-265

Dizon AE, Brill RW, Yuen HSH (1978) Correlations between environment, physiology, and activity and its effects on thermoregulation in skipjack tuna, Katsuwonus pelamis. In: Sharp 
GD, Dizon AE (eds) The Physiological Ecology of Tunas, Academic Press, New York, pp 233-259

Domeier ML, Keifer D, Nasby-Lucas N, Wagschal A, O'Brien F (2004) Tracking Pacific bluefin tuna (Thunnus thynnus orientalis) in the northeastern Pacific with an automated algorithm that estimates latitude by matching sea-surface-temperature data from satellites with temperature data from tags on fish. Fish Bull 103:292-306

Domokos R, Seki MP, Polovina JJ, Hawn DR (2007) Oceanographic investigation of the American Samoa albacore (Thunnus alalunga) habitat and longline fishing grounds. Fish Oceanogr 16:555-572

Douglas RH (2001) The ecology of teleost fish visual pigments: A good example of sensory adaptation to the environment. In: Barth FG, Schmid A (eds) Ecology of Sensing, SpringerVerlag, Berlin, pp 216-235

Dowis HJ, Sepulveda CA, Graham JB, Dickson KA (2003) Swimming performance studies on the eastern Pacific bonito Sarda chiliensis, a close relative of the tunas (family Scombridae). II. Kinematics. J Exp Biol 206:2749-2758

Drazen JC, Seibel BA (2007) Depth-related trends in metabolism of benthic and benthopelagic deep-sea fishes. Limnol Oceanogr 52:2306-2316

Evans K, Baer H, Bryant E, Holland M, Rupley T, Wilcox C (2011) Resolving estimation of movement in a vertically migrating pelagic fish: Does GPS provide a solution? J Exp Mar Biol Ecol 398:9-17

Evans K, Langley A, Clear NP, Williams P, Patterson T, Sibert J, Hampton J, Gunn JS (2008) Behaviour and habitat preferences of bigeye tuna (Thunnus obesus) and their influence on longline fishery catches in the western Coral Sea. Can J Fish Aquat Sci 65:2427-2443

Farrell AP (1991) From hagfish to tuna: A perspective on cardiac function in fish. Physiol Zool 64:1137-1164

Farrell AP (1996) Features heightening cardiovascular performance in fishes, with special reference to tunas. Comp Biochem Physiol 113A:61-67

Farrell AP, Davie PS, Franklin CE, Johansen JA, Brill RW (1992) Cardiac physiology in tunas. 1. In vitro perfused heart preparations from yellowfin and skipjack tunas. Can J Zool 70:12001210

Farwell CJ (2001) Tunas in captivity. In: Block BA, Stevens ED (eds) Fish Physiology, Volume 19. Academic Press, San Diego, pp 391-413 
Fitzgibbon QP, Seymour CA, Buchanan J, Musgrove R, Carragher J (2010) Effects of hypoxia on oxygen consumption, swimming velocity and gut evacuation in southern bluefin tuna (Thunnus maccoyii). Environ Biol Fish 89:59-69

Fitzgibbon QP, Seymour RS, Ellis D, Buchanan J (2007) The energetic consequence of specific dynamic action in southern bluefin tuna Thunnus maccoyii. J Exp Biol 210:290-298

Friedlander MJ, Kotchabhakdi N, Prosser CL (1976) Effects of cold and heat on behavior and cerebellar function in goldfish. J Comp Physiol 112:19-45

Fritsches KA, Marshall NJ, Warrant EJ (2003) Retinal specializations in the blue marlin: Eyes designed for sensitivity to low light levels. Mar Freshwater Res 54:333-341

Fritsches KA, Brill RW, Warrant EJ (2005) Warm eyes provide superior vision in swordfishes. Curr Biol 15:55-58

Fritsches KA, Partridge JC, Pettigrew JD, Marshall NJ (2000) Colour vision in billfish. Phil Trans Roy Soc B 355:1253-1256

Fritsches KA, Warrant EJ (2004) Do tuna and billfish see colours? Pelagic Fisheries Research Program Newsletter 9:1-4. University of Hawaii, Honolulu, HI

Fudge DS, Stevens ED (2005) The visceral retia mirabilia of tuna and sharks: An annotated translation and discussion of the Eschricht \& Müller 1835 paper and related papers. Guelph Ichthyology Reviews 4:92pp

Fudge DS, Stevens ED, Ballantyne JS (1997) Enzyme adaptation along a heterothermic tissue: The visceral retia mirabilia of the bluefin tuna. Am J Physiol 272:R1834-R1840

Fujioka K, Masujima M, Boustany A, Kitagawa T (2017). Horizontal movements of Pacific bluefin tuna. In: Kitagawa T, Kimura S (eds) Biology and Ecology of Bluefin Tuna, CRC Press, Boca Raton, FL, pp 101-122

Funakoshi S, Wada K, Suzuki T (1985) Development of the rete mirabile with growth and muscle temperature in the young bluefin tuna. Bull Jpn Soc Sci Fish 51:1971-1975

Galli GL, Lipnick MS, Block BA (2009a) Effect of thermal acclimation on action potentials and sarcolemmal $\mathrm{K}^{+}$channels from Pacific bluefin tuna cardiomyocytes. Am J Physiol 29:R502R509

Galli GL, Lipnick MS, Shiels HA, Block BA (2011) Temperature effects on $\mathrm{Ca}^{2+}$ cycling in scombrid cardiomyocytes: A phylogenetic comparison. J Exp Biol 214:1068-1076

Galli GL, Shiels HA, Brill RW (2009b) Temperature sensitivity of cardiac function in pelagic fishes with different vertical mobilities: yellowfin tuna (Thunnus albacares), bigeye tuna 
(Thunnus obesus), mahimahi (Coryphaena hippurus), and swordfish (Xiphias gladius).

Gamperl KA, Driedzic WE (2009) Cardiovascular function and cardiac metabolism. In: Richards JG, Farrell AP, Brauner CJ (eds) Fish Physiology, Volume 27, Academic Press, London, pp 302-361

Garcia HE, Locarnini RA, Boyer TP, Antonov JI, Baranova OK, Zweng MM, Johnson DR (2009) World Ocean Atlas 2009, Volume 3: Dissolved Oxygen, Apparent Oxygen Utilization, and Oxygen Saturation. In: Levitus S (ed) NOAA Atlas NESDIS 70, U.S. Government Printing Office, Washington, D.C. 344 pp

Gibbs RH, Collette BB (1967) Comparative anatomy and systematics of the tunas, genus Thunnus. Fish Bull 66:65-130

Giovane A, Greco G, Maresca A, Tota B (1980) Myoglobin in the heart ventricle of tuna and other fishes. Experientia 36:219-220

Glass CW, Wardle CS, Mojsiewicz WR (1986) A light intensity threshold for schooling in the Atlantic mackerel Scomber scombrus. J Fish Biol. 29:71-81, Supplement A

Godsil HC, Beyers RD (1944) A systematic study of the Pacific tunas. California Fish Game 60:1-131

Gooding RM, Neill WH, Dizon AE (1981) Respiration rates and low-oxygen tolerance limits in skipjack tuna, Katsuwonus pelamis. Fish Bull 79:31-48

Graham BS, Grubbs D, Holland K, Popp BN (2007) A rapid ontogenetic shift in the diet of juvenile yellowfin tuna from Hawaii. Mar Biol 150:647-658

Graham JB, Dickson KA (1981) Physiological thermoregulation in the albacore Thunnus alalunga. Physiol Zool 54:470-486

Graham JB, Dickson KA (2000) The evolution of thunniform locomotion and heat conservation in scombrid fishes: New insights based on the morphology of Allothunnus fallai. Zool J Linn Soc Lond 129:419-466

Graham JB, Dickson KA (2001) Anatomical and physiological specializations for endothermy. In: Block BA, Stevens ED (eds) Fish Physiology, Volume 19. Academic Press, San Diego, pp 121-165

Graham JB, Koehrn FJ, Dickson KA (1983) Distribution and relative proportions of red muscle in scombrid fishes consequences of body size and relationships to locomotion and endothermy. Can J Zool 61:2087-2096 
Graham JB, Lowell WR, Lai NC, Laurs RM (1989) $\mathrm{O}_{2}$ tension, swimming-velocity, and thermal effects on the metabolic rate of the Pacific albacore Thunnus alalunga. Exp Biol 48:89-94

Graham MS, Farrell AP (1989) The effect of temperature-acclimation and adrenaline on the performance of a perfused trout heart. Physiol Zool 62:38-61

Gunn J, Block B (2001) Advances in acoustic, archival, and satellite tagging of tunas. In: Block BA, Stevens ED (eds) Fish Physiology, Volume 19. Academic Press, San Diego, pp 167-224

Hanamoto E (1987) Effect of oceanographic environment on bigeye tuna distribution. Bull Jpn Soc Fish Oceanogr 51:203-215

Hanyu I, Ali MA (1964) Electroretinogram and its flicker fusion frequency at different temperatures in light adapted salmon (Salmo salar). J Cell Compar Physl 63:309-322

Hanyu I, Tamura T, Niwa H (1973) Electroretinograms and retinal ganglion cell responses in the skipjack tuna. Bull Jpn Soc Sci Fish 39:265-273

Harder W (1975) Anatomy of Fishes. Volume 1, Schweizerbart, Stuttgart

Haverinen J, Vornanen M (2009) Responses of action potential and $\mathrm{K}^{+}$currents to temperature acclimation in fish hearts: phylogeny or thermal preferences? Physiol Biochem Zool 82:468482

Hobday AJ, Evans K, Eveson JP, Farley JH, Hartog JR, Basson M, Patterson TA (2017). Distribution and migration - southern bluefin tuna (Thunnus maccoyii). In: Kitagawa T, Kimura S (eds) Biology and Ecology of Bluefin Tuna, CRC Press, Boca Raton, FL, pp 189210

Holland KN, Brill RW, Chang RKC (1990a) Horizontal and vertical movements of Pacific blue marlin captured using sport fishing techniques. Fish Bull 88:397-402

Holland KN, Brill RW, Chang RKC (1990b) Horizontal and vertical movements of yellowfin and bigeye tuna associated with fish aggregating devices. Fish Bull 88:493-508

Holland K, Brill R, Chang R, Sibert J, Fournier D (1992) Physiological and behavioral thermoregulation in bigeye tuna (Thunnus obesus). Nature 358:410-412

Holland KN, Grubbs RD (2007) Fish visitors to seamounts: Tunas and billfish at seamounts. In: Pitcher TJ, Morato T, Hart PJB, Clark MR, Haggan N, Santos RS (eds) Seamounts: Ecology, Fisheries \& Conservation, Blackwell Publishing, Oxford, UK, pp 189-201

Holland KN, Sibert JR (1994) Physiological thermoregulation in bigeye tuna, Thunnus obesus. Environ Biol Fish 40:319-327 
Holtz SB (2013) Extraocular muscles as a potential heat source for cranial endothermy in tunas. MS thesis, California State University Fullerton, 49 pp

Horodysky AZ, Brill RW, Cooke, SJ (2015) Physiology in the service of fisheries science: why thinking mechanistically matters. Rev Fish Biol Fisher 25:425-447

Horodysky AZ, Brill RW, Warrant EJ, Musick JA, Latour RJ (2010) Comparative visual function in four piscivorous fishes inhabiting Chesapeake Bay. J Exp Biol 213:1751-1761

Horodysky AJ, Cooke SJ, Graves JE, Brill RW (2016) Fisheries conservation on the high seas: Linking conservation physiology and fisheries ecology for the management of pelagic fishes. Conserv Physiol 4: (doi: 10.1093/conphys/cov059)

Hove-Madsen L, Llach A, Tort L (2000) $\mathrm{Na}^{+} / \mathrm{Ca}^{2+}$-exchange activity regulates contraction and $\mathrm{SR} \mathrm{Ca}^{2+}$ content in rainbow trout atrial myocytes. Am J Physiol 279:R1856-R1864

Howell EA, Hawn DR, Polovina JJ (2010) Spatiotemporal variability in bigeye tuna (Thunnus obesus) dive behavior in the central North Pacific Ocean. Prog Oceanogr 86:81-93

Hunter JR (1968) Effects of light on schooling and feeding of jack mackerel, Trachurus symmetricus. J Fish Res Board Can 25:393-407

Hughes A (1977) The topography of vision in mammals of contrasting life style: Comparative optics and retinal organisation. In: Crescitelli F (ed) Handbook of Sensory Physiology, Volume VII/5, Springer, Berlin, pp 613-756

Ishibashi Y, Honryo T, Saida K, Hagiwara A, Miyashita S, Sawada Y, Okada T, Kurata M (2009) Artificial lighting prevents high night-time mortality of juvenile Pacific bluefin tuna, Thunnus orientalis, caused by poor scotopic vision. Aquaculture 293:157-163

Itano DG (2004) A handbook for the identification of yellowfin and bigeye tunas. 17th Meeting of the Standing Committee on Tuna and Billfish, Majuro, Marshall Islands (9-18 August 2004), Fishing Technology Working Group, INF-FTWG-5.

Jensen FB, Nikinmaa M, Weber RE (1993) Environmental perturbations of oxygen transport in teleost fishes: Causes, consequences and compensations. In: Rankin JC, Jensen FB (eds) Fish Ecophysiology, Chapman and Hall, London, pp 161-179

Jerlov NG (1976) Marine Optics. Elsevier, Amersterdam 231 pp

Johnston IA, Brill RW (1984) Thermal dependence of contractile properties of single skinned muscle fibers from Antarctic and various warm water marine fishes including skipjack tuna (Katsuwonus pelamis) and kawakawa (Euthynnus affinis). J Comp Physiol 155B:63-70 
Jones DR, Brill RW, Mense DC (1985) The influence of blood gas properties on gas tensions and $\mathrm{pH}$ of ventral and dorsal aorta blood in free-swimming tuna (Euthynnus affinis). J Exp Biol 120:201-213

Josse E, Bach P, Dagorn L (1998) Simultaneous observations of tuna movements and their prey by sonic tracking and acoustic surveys. Hydrobiologia 372:61-69

Kawamura G, Nishimura W, Ueda S, Nishi T (1981a) Color vision and spectral sensitivity in tunas and marlins. Bull Jpn Soc Sci Fish 47:481-485

Kawamura G, Nishimura, W, Ueda S, Nishi T (1981b) Vision in tunas and marlins. Mem Kagoshima Univ Res Center for the South 1:3-47

Keen JE, Farrell AP, Tibbits GF, Brill RW (1992) Cardiac Physiology in Tunas. 2. Effect of ryanodine, calcium, and adrenaline on force frequency relationships in atrial strips from skipjack tuna, Katsuwonus pelamis. Can J Zool 70:1211-1217

Keen JE, Vianzon DM, Farrell AP, Tibbits GF (1993) Thermal acclimation alters both adrenergic sensitivity and adrenoreceptor density in cardiac tissue of rainbow trout. J Exp Biol $181: 27-47$.

Kishinouye K (1923) Contributions to the comparative study of the so-called scombroid fishes. Journal of the College of Agriculture, Tokyo Imperial University 8:293-475

Kitagawa T, Kimura S, Nakata H, Yamada H (2004) Diving behavior of immature, feeding Pacific bluefin tuna (Thunnus thynnus orientalis) in relation to season and area: The East China Sea and the Kuroshio-Oyashio transition region. Fish Oceanogr 13:161-180

Kitagawa T, Kimura S, Nakata H, Yamada H (2006) Thermal adaptation of Pacific bluefin tuna Thunnus orientalis to temperate waters. Fisheries Sci 72:149-156

Kitagawa T, Boustany AM, Farwell CJ, Williams TD, Castleton MR, Block BA (2007a) Horizontal and vertical movements of juvenile bluefin tuna (Thunnus orientalis) in relation to seasons and oceanographic conditions in the eastern Pacific Ocean. Fisheries Oceanogr 16:409-421

Kitagawa T, Kimura S, Nakata H, Yamada H (2007b) Why do young Pacific bluefin tuna repeatedly dive to depths through the thermocline? Fisheries Sci 73:98-106

Kitagawa T, Fujioka K (2017) Rapid ontogenetic shift in juvenile Pacific bluefin diet. Mar Ecol Prog Ser 571:253-257

Kirby DS (2001) On the integrated study of tuna behavior and spatial dynamics: Tagging and modeling as complementary tools. In: Sibert JR, Neilsen JL (eds) Electronic Tagging and Tracking in Marine Fisheries, Kluwer Academic Publishers, Dordecht, Netherlands, pp 407421 
Kolbinger W, Wagner D, Wagner JJ (1996) Control of rod retinomotor movements in teleost retinae: the role of dopamine in mediating light-dependent and circadian signals. Cell Tissue Res 285:445-451

Konishi J, Hickman CP (1964) Temperature acclimation in the central nervous system of trout (Salmo gairdneri). Comp Biochem Physiol 13:433-442

Korsmeyer KE, Dewar H, Lai, NC, Graham JB (1996a) Tuna aerobic swimming performance: Physiological and environmental limits based on oxygen supply and demand. Comp Biochem Physiol 113B:45-56

Korsmeyer KE, Dewar H, Lai NC, Graham JB (1996b) The aerobic capacity of tunas: Adaptation for multiple metabolic demands. Comp Biochem Physiol 113A:17-24

Kröger RHH, Fritsches KA, Warrant EJ (2009) Lens optical properties in the eyes of large marine predatory teleosts. J Comp Physiol 195A:175-182

Kubo T, Sakamoto W, Murata O, Kumai H (2008) Whole-body heat transfer coefficient and body temperature change of juvenile Pacific bluefin tuna Thunnus orientalis according to growth. Fisheries Sci 74:995-1004

Landeira-Fernandez AM, Castilho PC, Block BA (2012) Thermal dependence of cardiac SR $\mathrm{Ca}^{2+}$-ATPase from fish and mammals. J Therm Biol 37:217-223

Landeira-Fernandez AM, Morrissette JM, Blank JM, Block BA (2004) Temperature dependence of the $\mathrm{Ca}^{2+}$-ATPase (SERCA2) in the ventricles of tuna and mackerel. Am J Physiol 286:R398-R404

Laurs RM, Fiedler PC, Montgomery DR (1984) Albacore tuna catch distributions relative to environmental features observed from satellites. Deep-Sea Res 31:1085-1099

Laurs RM, Yuen HS, Johnson JH (1977.) Small-scale movements of albacore, Thunnus alalunga, in relation to ocean features as indicated by ultrasonic tracking and oceanographic sampling. Fish Bull 75:347-355

Lawson GL, Castleton MR, Block BA (2010) Movements and diving behavior of Atlantic bluefin tuna Thunnus thynnus in relation to water column structure in the northwestern Atlantic. Mar Ecol-Prog Ser 400:245-265

Lehodey P, Hampton J, Brill RW, Nicol S, Senina I, Calmettes B, Pörtner HO, Bopp L, Ilyina T, Bell JD, Sibert J (2011) Vulnerability of oceanic fisheries in the tropical Pacific to climate change. In: Bell JD, Johnson JE, Hobday AJ (eds) Vulnerability of Tropical Pacific Fisheries and Aquaculture to Climate Change. Secretariat of the Pacific Community, Noumea, New Caledonia, pp 433-492 
Lilly LW, Bonaventura J, Lipnick MS, Block BA (2015) Effect of temperature acclimation on red blood cell oxygen affinity in Pacific bluefin tuna (Thunnus orientalis) and yellowfin tuna (Thunnus albacares). Comp Biochem Physiol 181A:36-44

Linthicum DS, Carey FG (1972) Regulation of brain and eye temperatures of the bluefin tuna. Comp Biochem Physiol 43A:425-433

Llach A, Tibbits GF, Sedarat F, Tort L, Hove-Madsen L (2001) Low temperature reduces $\mathrm{Na}^{+}-$ $\mathrm{Ca}^{2+}$ exchange rate but not SR Ca ${ }^{2+}$ release in trout atrial myocytes. Biophys $\mathrm{J} 80$ : 585A

Loew ER, McFarland WN, Margulies D (2002) Developmental changes in the visual pigments of the yellowfin tuna, Thunnus albacares. Mar Freshw Behav Physiol 35:235-246

Lowe T, Brill R, Cousins K (2000) Blood $\mathrm{O}_{2}$-binding characteristics of bigeye tuna (Thunnus obesus), a high-energy-demand teleost that is tolerant of low ambient $\mathrm{O}_{2}$. Mar Biol 136:10871098

Lutcavage ME, Brill RW, Skomal GB, Chase BC, Goldstein JL, Tutein J (2000) Tracking adult northern bluefin tuna (Thunnus thynnus) in the northwestern Atlantic using ultrasonic telemetry. Mar Biol 137:347-358

Lyle M, Barron J, Bralower TJ, Huber M, Lyle AO, Ravelo AC, Rea DK, Wilson PA (2008) Pacific Ocean and Cenozoic evolution of climate. Rev Geophys 46:1-47

Lythgoe JN (1979) The Ecology of Vision. Clarendon Press, Oxford

Macdougall JD (1996) A Short History of Planet Earth, Mountains, Mammals, Fire, and Ice. John Wiley and Sons, New York

Magnuson JJ (1963) Tuna behavior and physiology, a review. Methodological Paper No. 5. In: Rosa H, Jr. (ed) Proceedings of the World Scientific Meeting on the Biology of Tunas and Related Species. FAO Fisheries Reports 3:1057-1066

Magnuson JJ (1973) Comparative study of adaptations for continuous swimming and hydrostatic equilibrium of scombroid and xiphoid fishes. Fish Bull 71:337-356

Magnuson JJ (1978) Locomotion by scombrid fishes: Hydromechanics morphology and behavior. In: Hoar WS, Randall DJ (eds) Fish Physiology Volume 7. Academic Press, New York, pp 239-313

Magnuson JJ, Weininger D (1978) Estimation of minimum sustained speed and associated body drag of scombrids. In: Sharp GD, Dizon AE (eds) The Physiological Ecology of Tunas.

Academic Press, New York, pp 293-311

Malte H, Larsen C, Musyl M, Brill R (2007) Differential heating and cooling rates in bigeye tuna (Thunnus obesus Lowe): A model of non-steady state heat exchange. J Exp Biol 210:2618- 
Marcinek DJ, Blackwell SB, Dewar H, Freund EV, Farwell C, Dau D, Seitz AC, Block BA (2001) Depth and muscle temperature of Pacific bluefin tuna examined with acoustic and popup satellite archival tags. Mar Biol 138:869-885

Margulies D, Scholey VP, Wexler JB, Stein MS, Deriso RB, Compeán GA (2013) The IATTC Achotines Laboratory-a world leader in tuna research. INFOFISH International 2:24-28

Marshall, C., Elias, C., Xue, X. H., Le, H. D., Omelchenko, A., Hryshko, L. V., \& Tibbits, G. F. (2002). Determinants of cardiac $\mathrm{Na}+\mathrm{Ca} 2+$ exchanger temperature dependence: NH2-terminal transmembrane segments. Amer J Physiol-Cell Physiol, 283(2), C512-C520.

Masuma S, Kawamura G, Tezuka N, Koiso M, Namba K (2001) Retinomotor responses of juvenile bluefin tuna Thunnus thynnus. Fisheries Sci 67:228-231

Matsumoto T, Okada T, Sawada Y, Ishibashi Y (2011a) Changes in the scotopic vision of juvenile Pacific bluefin tuna (Thunnus orientalis) with growth. Fish Physiol Biochem 37:693700

Matsumoto T, Okada T, Sawada Y, Ishibashi Y (2011b) Visual spectral sensitivity of photopic juvenile Pacific bluefin tuna (Thunnus orientalis). Fish Physiol Biochem 38:911-917

Matsumoto T, Ihara H, Ishida Y, Okada T, Kurata M, Sawada Y, Ishibashi Y (2009) Electroretinographic analysis of night vision in juvenile Pacific bluefin tuna (Thunnus orientalis). Biol Bull 217:142-150

McKenzie DJ, Axelsson M, Chabot D, Claireaux G, Cooke S, Corner R, de Boeck G, Domenici P, Guerreiro P, Hamer B, Jørgensen C, Killen S, Lefevre S, Marras S, Michaelidis B, Nilsson G, Peck M, Pérez-Ruzafa A, Rijnsdorp A, Shiels H, Steffensen J, Svendsen J, Svendsen M, Teal L, van der Meer J, Wang T, Wilson J, Wilson R, Metcalfe J (2016) Conservation physiology of marine fishes: State of the art and prospects for policy. Conserv Physiol 4 (doi;10.1093/conphys/cow046)

Mejuto J, Autón U, Quintans M (2005) Visual acuity and olfactory sensitivity in the swordfish (Xiphias gladius) for the detection of prey during field experiments using the surface longline gear with different bait types. Collective Volume of Scientific Papers-ICCAT 58:1501-1510

Mislan KAS, Dunne JP, Sarmiento J L (2016) The fundamental niche of blood oxygen binding in the pelagic ocean. Oikos 125:938-949

Miya M, Friedman M, Satoh TP, Takeshima H, Sado T, Iwasaki W, Yamanoue Y, Nakatani M. Mabuchi K. Inoue JG, Poulsen JY, Fukunaga T, Sato Y, Nishida M (2013) Evolutionary origin of the Scombridae (tunas and mackerels): Members of a Paleogene adaptive radiation with 14 other pelagic fish families. PloS One 8:e73535

Monsch KA (2000) The phylogeny of the scombroid fishes. PhD thesis, University of Bristol. 
Montgomery JC, Macdonald JA (1990) Effects of temperature on nervous system: implications for behavioral performance. Am J Physiol 259:191-196

Morinaga T, Imazeki A, Arakawa H, Koike T (1993a) Underwater visibilities in different optical type water masses of the oceans. La Mer 31:11-18

Morinaga T, Imazeki A, Morikawa Y (1993b) Distributions of underwater spectral irradiance and optical environments of tuna fishing grounds in the three oceans. La Mer 31:49-57

Motani R, Rothschild BM, Wahl W (1999) Large eyeballs in diving ichthyosaurs - the huge eyes of these extinct reptiles may have been useful deep in the ocean. Nature 402:747

Moyes CD, Mathieu-Costello OA, Brill RW, Hochachka PW (1992) Mitochondrial metabolism of cardiac and skeletal muscles from a fast (Katsuwonus pelamis) and a slow (Cyprinus carpio) fish. Can J Zool 70:1246-1253

Muhling BA, Lamkin JT, Alemany F, García A, Farley J, Ingram Jr GW, Alvarez Berastegui D, Reglero P, Laiz Carrion R (2017) Reproduction and larval biology in tunas, and the importance of restricted area spawning grounds. Rev Fish Biol Fisher 1-36. DOI $10.1007 / \mathrm{s} 11160-017-9471-4$

Musyl MK, Brill RW, Boggs CH, Curran DS, Kazama TK, Seki MP (2003) Vertical movements of bigeye tuna (Thunnus obesus) associated with islands, buoys, and seamounts near the main Hawaiian Islands from archival tagging data. Fish Oceanogr 12:152-169

Musyl MK, McNaughton LM, Swimmer JY, Brill RW (2004) Convergent evolution of vertical movement behavior in swordfish, bigeye tuna, and bigeye thresher sharks. Pelagic Fisheries Research Program Newsletter 9:1-4

Nakamura EL (1968) Visual acuity of two tunas, Katsuwonus pelamis and Euthynnus affinis. Copeia 1:41-49

Nakamura EL (1972) Development and uses of facilities for studying tuna behavior. In: Winn HW, Olla BL (eds) Behavior of Marine Animals, Volume 2. Plenum Publishing Corporation, New York, pp 245-277

Niwa H, Tanura T, Hanyu I (1975) Spectral sensitivity curves of the skipjack tuna and the frigate mackerel. Bull Jpn Soc Sci Fish 41:923-927

Olla BL, Marchioni WW (1968) Rhythmic movements of cones in the retina of bluefish, Pomatomus saltatrix, held in constant darkness. Biol Bull 135:530-536

Orbesen ES, Snodgrass D, Shideler GS, Brown CA, Walter JF (2017) Diurnal patterns in Gulf of Mexico epipelagic predator interactions with pelagic longline gear: implications for target 
species catch rates and bycatch mitigation. Bull Mar Sci. 93:

https://doi.org/10.5343/bms.2016.1008

Orrell TM, Collette BB, Johnson GD (2006) Molecular data support separate scombroid and xiphioid clades. Bull Mar Sci 79:505-519

Patrick SM, White E, Brill RW, Shiels HA (2011) The effect of stimulation frequency on the transmural ventricular monophasic action potential in yellowfin tuna Thunnus albacares. $\mathrm{J}$ Fish Biol 78:651-658

Perry SF, Daxboeck C, Emmet B, Hochachka PW, Brill RW (1985) Effects of temperature change on acid-base regulation in skipjack tuna (Katsuwonus pelamis) blood. Comp Biochem Physiol 81A:49-53

Perry SF, Jonz MG, Gilmour KM (2009) Oxygen sensing and the hypoxic ventilator response. In: Richard JG, Farrell AP, Brauner CJ (eds) Fish physiology, Volume 27, Academic Press, New York, pp 193-253

Pettigrew JD, Dreher CS, Hopkins MJ, McCall MJ, Brown M (1988) Peak density and distribution of ganglion cells in the retinae of microchiropteran bats: Implications for visual acuity. Brain Behav Evolut 32:39-56

Pope EC, Hays GC, Thys TM, Dole TK, Sims DW, Queiroz N, Hobson VJ, Kubicek L, Houghton JDR (2010) The biology and ecology of the ocean sunfish Mola mola: A review of current knowledge and future research perspectives. Rev Fish Biol Fisher 20:471-487

Powers DA, Martin JP, Garlick RL, Fyhn HJ (1979) The effect of temperature on the oxygen equilibria of fish hemoglobins in relation to thermal variability. Comp Biochem Physiol 62A:87-94

Prince ED, Goodyear CP (2007) Consequences of ocean scale hypoxia constrained habitat for tropical pelagic fishes. Gulf Carib Res 19:17-20

Prince ED, Luo J, Goodyear CP, Hoolihan JP, Snodgrass D, Orbesen ES, Serafy JE, Ortiz M, Schirripa MJ (2010) Ocean scale hypoxia-based habitat compression of Atlantic istiophorid billfishes. Fish Oceanog 19:448-462

Raye GD, Weng KS (2015) An aerobic scope-based habitat suitability index for predicting the effects of multi-dimensional climate change stressors on marine teleosts. Deep Sea Res. II 113:208-290

Reilly CRL, Thompson SH (2007) Temperature effects on low-light vision in juvenile rockfish (Genus Sebastes) and consequences for habitat utilization. J Comp Physiol 193A:943-953

Rossi-Fanelli A, Antonini E (1960) Oxygen equilibrium of haemoglobin from Thunnus thynnus. Nature 186:895-896 
Runcie RM, Dewar H, Hawn D, Frank LR, Dickson KA (2009) Evidence for cranial endothermy in the opah (Lampris guttatus). J Exp Biol 212:461-470

Sawada Y, Okada T, Miyashita S, Murata O. Kimai H (2005) Completion of the Pacific bluefin tuna Thunnus orientalis (Temminck et Schlegel) life cycle. Aquac Res 36:413-421

Schaefer KM (1984) Swimming performance, body temperatures and gastric evacuation times of the black skipjack, Euthynnus lineatus. Copeia, 1984:1000-1005

Schaefer KM (1985) Body temperatures in troll caught frigate tuna, Auxis thazard. Copeia, $1985: 231-233$

Schaefer KM (2001) Reproductive biology of tunas. Fish Physiol 19:225-270

Schaefer, KM, Fuller DW (2002) Movements, behavior, and habitat selection of bigeye tuna (Thunnus obesus) in the eastern equatorial Pacific, ascertained through archival tags. Fish Bull 100:765-788

Schaefer, KM, Fuller DW (2005) Behavior of bigeye (Thunnus obesus) and skipjack (Katsuwonus pelamis) tunas within aggregations associated with floating objects in the equatorial eastern Pacific. Mar Biol 146:781-792

Schaefer KM, Fuller DW (2007) Vertical movement patterns of skipjack tuna (Katsuwonus pelamis) in the eastern equatorial Pacific Ocean, as revealed with archival tags. Fish Bull 105:379-389

Schaefer KM, Fuller DW (2010) Vertical movements, behavior, and habitat of bigeye tuna (Thunnus obesus) in the equatorial eastern Pacific Ocean, ascertained from archival tag data. Mar Biol 157:2625-2642

Schaefer KM, Fuller DW, Block BA (2007) Movements, behavior, and habitat utilization of yellowfin tuna (Thunnus albacares) in the northeastern Pacific Ocean, ascertained through archival tag data. Mar Biol 152:503-525

Schaefer KM, Fuller DW, Block BA (2009) Vertical movements and habitat utilization of skipjack (Katsuwonus pelamis), yellowfin (Thunnus albacares), and bigeye (Thunnus obesus) tunas in the equatorial eastern Pacific Ocean, as ascertained through archival tag data. In: Sibert JR, Nielsen JL (eds) Electronic Tagging and Tracking of Marine Animals with Electronic Devices. Springer, Berlin, pp 121-144

Schaefer KM, Fuller DW, Block BA (2011) Movements, behavior, and habitat utilization of yellowfin tuna (Thunnus albacares) in the Pacific Ocean off Baja California, Mexico, determined from archival tag data analyses, including unscented Kalman filtering. Fish Res $112: 22-37$ 
Schirripa MJ, Abascal F, Andrushchenko I, Diaz G, Mejuto J, Ortiz M, Santos N, Walter J (2016) A hypothesis of a redistribution of North Atlantic swordfish based on changing ocean conditions. Deep-Sea Res II (in press)

Sepulveda CA, Knight A, Nasby-Lucas N, Domeier ML (2010) Fine scale movements of the swordfish Xiphias gladius in the Southern California Bight. Fish Oceanogr 19:279-289

Sepulveda CA, Dickson KA (2000) Maximum sustainable speeds and cost of swimming in juvenile kawakawa tuna (Euthynnus affinis) and chub mackerel (Scomber japonicus). J Exp Biol 203:3089-3101

Sepulveda CA, Dickson KA, Frank LR, Graham JB (2007) Cranial endothermy and a putative brain heater in the most basal tuna species, Allothunnus fallai. J Fish Biol 70:1720-1733

Sepulveda CA, Dickson KA, Graham JB (2003) Swimming performance studies on the eastern Pacific bonito Sarda chiliensis, a close relative of the tunas (family Scombridae) I. Energetics. J Exp Biol 206:2739-2748

Sepulveda CA, Dickson KA, Bernal D, Graham JB (2008) Elevated red myotomal muscle temperatures in the most basal tuna species, Allothunnus fallai. J Fish Biol 73:241-249

Sharp GD (2001) Tuna oceanography - an applied science. In: Block BA, Stevens ED (eds) Fish physiology, Volume 19. Academic Press, San Diego, pp 345-389

Sharp GD, Dizon AE (1978) The Physiologcal Ecology of Tunas. Academic Press, New York.

Shiao JC, Yui TF, Høie H, Ninnemann U, Chang SK (2009) Otolith O and C stable isotope compositions of southern bluefin tuna Thunnus maccoyii (Pisces: Scombridae) as possible environmental and physiological indicators. Zool Stud 48:71-82

Shiels HA, Blank JM, Farrell AP, Block BA (2004) Electrophysiological properties of the L-type $\mathrm{Ca}^{(2+)}$ current in cardiomyocytes from bluefin tuna and Pacific mackerel. Am J Physiol 286;R659-R668

Shiels HA, Di Maio A, Thompson S, Block BA (2011) Warm fish with cold hearts: Thermal plasticity of excitation-contraction coupling in bluefin tuna. Proc Roy Soc Lond B Bio 278:18-27

Shiels HA, Farrell AP (1997) The effect of temperature and adrenaline on the relative importance of the sarcoplasmic reticulum in contributing $\mathrm{Ca}^{2+}$ to force development in isolated ventricular trabeculae from rainbow trout. J Exp Biol 200:1607-1621

Shiels HA, Freund EV, Farrell AP, Block BA (1999) The sarcoplasmic reticulum plays a major role in isometric contraction in atrial muscle of yellowfin tuna. J Exp Biol 202:881-890 
Shiels HA, Galli GLJ, Block BA (2015) Cardiac function in an endothermic fish: Cellular mechanisms for overcoming acute thermal challenges during diving. Proc Roy Soc Lond B Bio 282:20141989

Shiels HA, Paajanen V, Vornanen M (2006) Sarcolemmal ion currents and sarcoplasmic reticulum $\mathrm{Ca}^{2+}$ content in ventricular myocytes from the cold stenothermic fish, the burbot (Lota lota). J Exp Biol 209:3091-3100

Shiels, HA, Sitsapesan, R (2015) Is there something fishy about the regulation of the ryanodine receptor in the fish heart? Exp Physiol 100:1412-1420.

Shiels HA, Vornanen M, Farrell AP (2000) Temperature-dependence of L-type $\mathrm{Ca}^{(2+)}$ channel current in atrial myocytes from rainbow trout. J Exp Biol 203:2771-2780

Shiels HA, Vornanen M, Farrell AP (2002) Effects of temperature on intracellular $\left[\mathrm{Ca}^{2+}\right]$ in trout atrial myocytes. J Exp Biol 205:3641-3650

Shiels, HA, Vornanen M, Farrell AP (2003) Acute temperature change modulates the response of $\mathrm{I}_{\mathrm{Ca}}$ to adrenergic stimulation in fish cardiomyocytes. Physiol Biochem Zool 76:816-824

Somiya H, Takei S, Mitani I (2000) Guanine and its retinal distribution in the tapetum of the bigeye tuna, Thunnus obesus. Ichthyol 47:367-372

Southwood A, Fritsches K, Brill R, Swimmer Y (2008) Sound, chemical, and light detection in sea turtles and pelagic fishes: sensory-based approaches to bycatch reduction in longline fisheries. Endang Species Res 5:225-238

Stevens ED, Lam HM, Kendall J (1974) Vascular anatomy of the counter-current heat exchanger of skipjack tuna. J Exp Biol 61:145-153

Stevens ED, Kanwisher JW, Carey FG (2000). Muscle temperature in free-swimming giant Atlantic bluefin tuna (Thunnus, thynnus L.). J Therm Biol 25:419-423

Stevens ED, McLeese JM (1984) Why bluefin tuna Thunnus thynnus have warm tummies: Temperature effect on trypsin and chymotrypsin. Am J Physiol 246:R487-R494

Stevens ED, Fry FEJ (1971) Brain and muscle temperatures in ocean caught and captive skipjack tuna. Comp Biochem Physiol 38A:203-211

Strasburg DW, Marr JC (1961) Banded color phases of two pelagic fishes, Coryphaena hippurus and Kastuwonus pelamis. Copeia 1961:226-228

Suzuki N, Chow S (2016) Phylogeny of bluefin tuna species. In: Kitagawa T, Kimura S (eds) Biology and Ecology of Bluefin Tuna. CRC Press, Boca Raton, FL, pp 3-15 
Swimmer Y, McNaughton L, Moyes C, Brill R (2005) Metabolic biochemistry of cardiac muscle in three tuna species (bigeye, Thunnus obesus, yellowfin, T. albacares, and skipjack, Katsuwonus pelamis) with divergent ambient temperature and oxygen tolerances. Fish Physiol Biochem 30:27-25

Tamura T, Hanyu I, Niwa H (1972) Spectral sensitivity and color vision in skipjack tuna and related species. Bull Jpn Soc Sci Fish 38:799-802

Tamura T, Wilsby WJ (1963) The visual sense of pelagic fishes especially the visual axis and accommodation. Bull Mar Sci Gulf Carib 13:433-448

Teo SLH, Boustany A, Dewar H, Stokesbury MJW, Weng KC, Beemer S, Seitz AC, Farwell CJ, Prince ED, Block BA (2007a) Annual migrations, diving behavior, and thermal biology of Atlantic bluefin tuna, Thunnus thynnus, on their Gulf of Mexico breeding grounds. Mar Biol $151: 1-18$

Teo SLH, Boustany AM, Block BA (2007b) Oceanographic preferences of Atlantic bluefin tuna, Thunnus thynnus, on their Gulf of Mexico breeding grounds. Mar Biol 152:1105-1119

Torisawa S, Orisawa T, Takagi T, Fukuda H, Ishibashi Y, Sawada Y, Okada T, Miyashita S, Suzuki K, Yamane T (2007a) Schooling behaviour and retinomotor response of juvenile Pacific bluefin tuna Thunnus orientalis under different light intensities. J Fish Biol 71:411420

Torisawa S, Takagi T, Ishibashi Y, Sawada Y, Yamane T (2007b) Changes in the retina cone density distribution and the retinal resolution during growth of juvenile Pacific bluefin tuna Thunnus orientalis. Fish Sci 73:1202-1204

Torisawa S, Fukuda H, Suzuki K, Takagi T (2011) Schooling behavior of juvenile Pacific bluefin tuna Thunnus orientalis depends on their vision development. J Fish Biol 79:12911303

Torisawa S, Fukuda H, Takagi T (2015) Visual physiology. In: Kitagawa T, Kimura S (eds) Biology and Ecology of Bluefin Tuna. CRC Press, Boca Raton, FL, pp 309-324

Tota B (1978) Functional cardiac morphology and biochemistry in Atlantic bluefin tuna. In: Sharp GD, Dizon AE (eds) The Physiological Ecology of Tunas. Academic Press, San Diego, pp 89-112

Truchot JP (1987) Comparative aspects of extracellular acid-base balance. Springer-Verlag, New York

Van den Burg EH, Peeters RR, Verhoye M, Meek J, Flik G, Van der Linden A (2005) Brain responses to ambient temperature fluctuations in fish: Reduction of blood volume and initiation of a whole-body stress response. J Neurophysiol 93:2849-2855 
Vornanen M, Shiels HA, Farrell AP (2002) Plasticity of excitation-contraction coupling in fish cardiac myocytes. Comp Biochem Physiol 132A:827-846

Wang SQ, Huang YH, Liu KS, Zhou ZQ (1997) Dependence of myocardial hypothermia tolerance on sources of activator calcium. Cryobiology 35:193-200

Warrant, EJ (1999) Seeing better at night: Life style, eye design and the optimum strategy of spatial and temporal summation. Vision Res 39:1611-1630

Warrant EJ (2004) Vision in the dimmest habitats on earth. J Comp Physiol 90A:765-789

Warrant EJ, Locket LA (2004) Vision in the deep sea. Biol Rev 79:671-712

Watanabe YY, Goldman KJ, Caselle JE, Chapman DD, Papastamatiou YP (2015) Comparative analyses of animal-tracking data reveal ecological significance of endothermy in fishes. Proc Natl Acad Sci USA 112:6104-6109

Weber RE, Fago A (2004) Functional adaptation and its molecular basis in vertebrate hemoglobins, neuroglobins and cytoglobins. Respir Physiol Neurobiol 144:141-159

Westneat MW, Wainwright SA (2001) Mechanical design for swimming: Muscle, tendon, and bone. In: Block BA, Stevens ED (eds) Fish Physiology, Volume 19. Academic Press, San Diego, pp 272-313

Whitlock RE, Walli A, Cermeño P, Rodriguez LE, Farwell C, Block BA (2013) Quantifying energy intake in Pacific bluefin tuna (Thunnus orientalis) using the heat increment of feeding. J Exp Biol 216:4109-4123

Widder EA (2002) Bioluminescence and the pelagic visual environment. Mar Freshw Behav Phy $35: 1-26$

Wilson SG, Lutcavage ME, Brill RW, Genovese MP, Cooper AB, Everly AE (2005) Movements of bluefin tuna (Thunnus thynnus) in the northwestern Atlantic Ocean recorded by pop-up satellite archival tags. Mar Biol 146:409-423

Yang TH, Lai NC, Graham JB, Somero GN (1992) Respiratory, blood, and heart enzymatic adaptations of Sebastolobus alascanus (Scorpaenidae: Teleostei) to the oxygen minimum zone: A comparative study. Biol Bull 183:490-498

Yen K-W, Lu H-J (2016) Spatial-temporal variations in primary productivity and population dynamics of skipjack tuna Katsuwonus pelamis in the western and central Pacific Ocean. Fish Sci 82: 563-571 

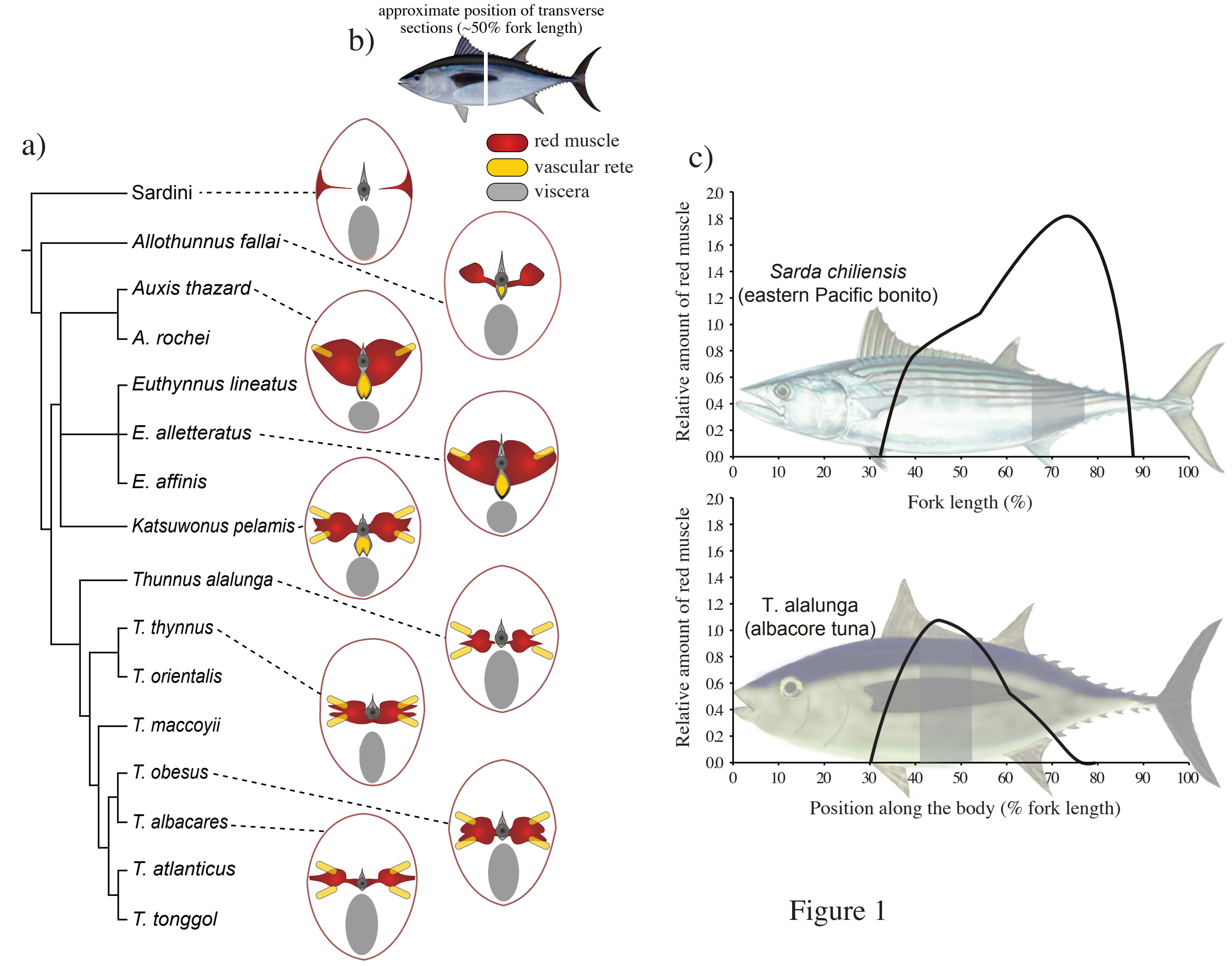

Figure 1 


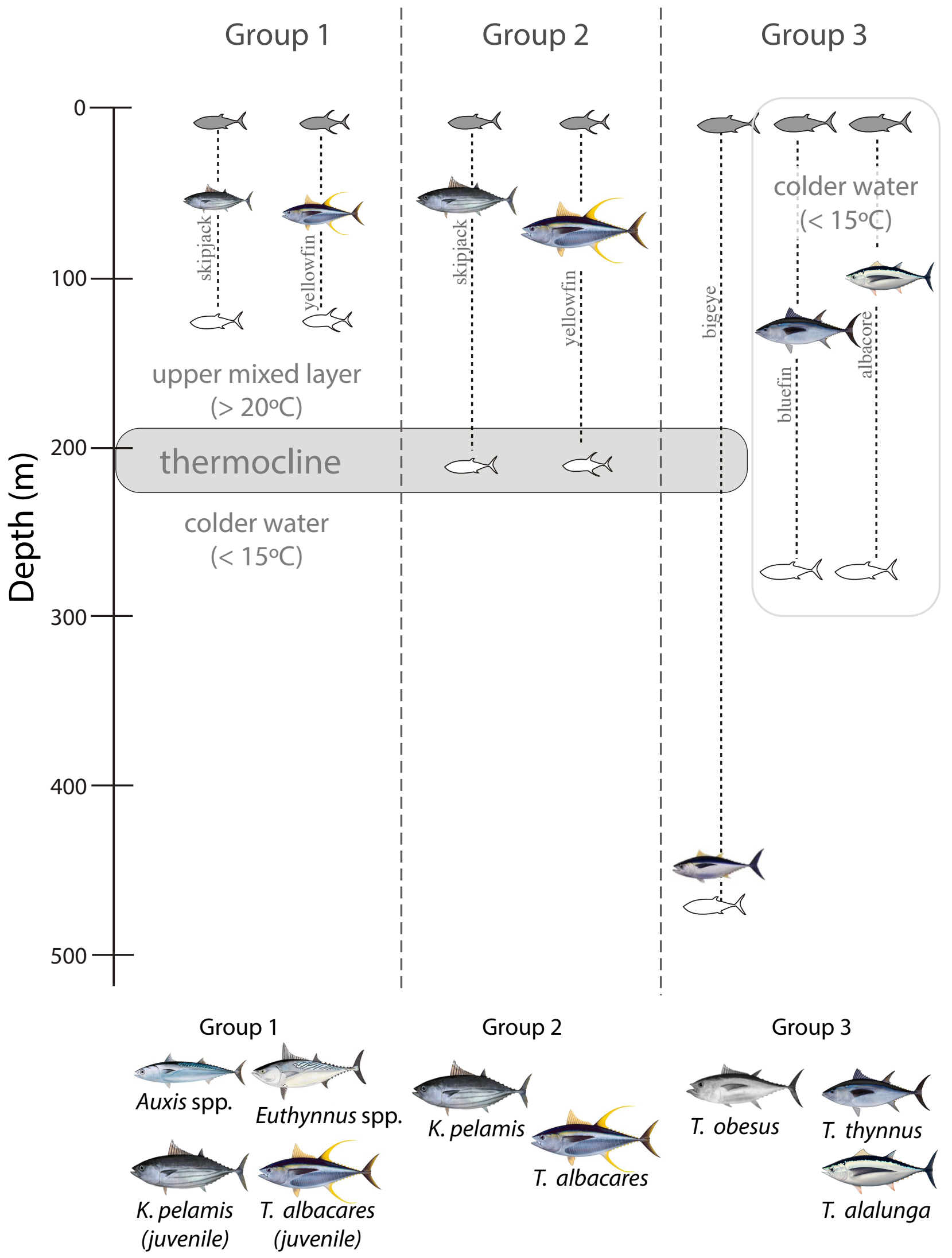

Figure 2 


\section{Local time $\left(2^{\circ} \mathrm{N} 95^{\circ} \mathrm{W}\right)$}
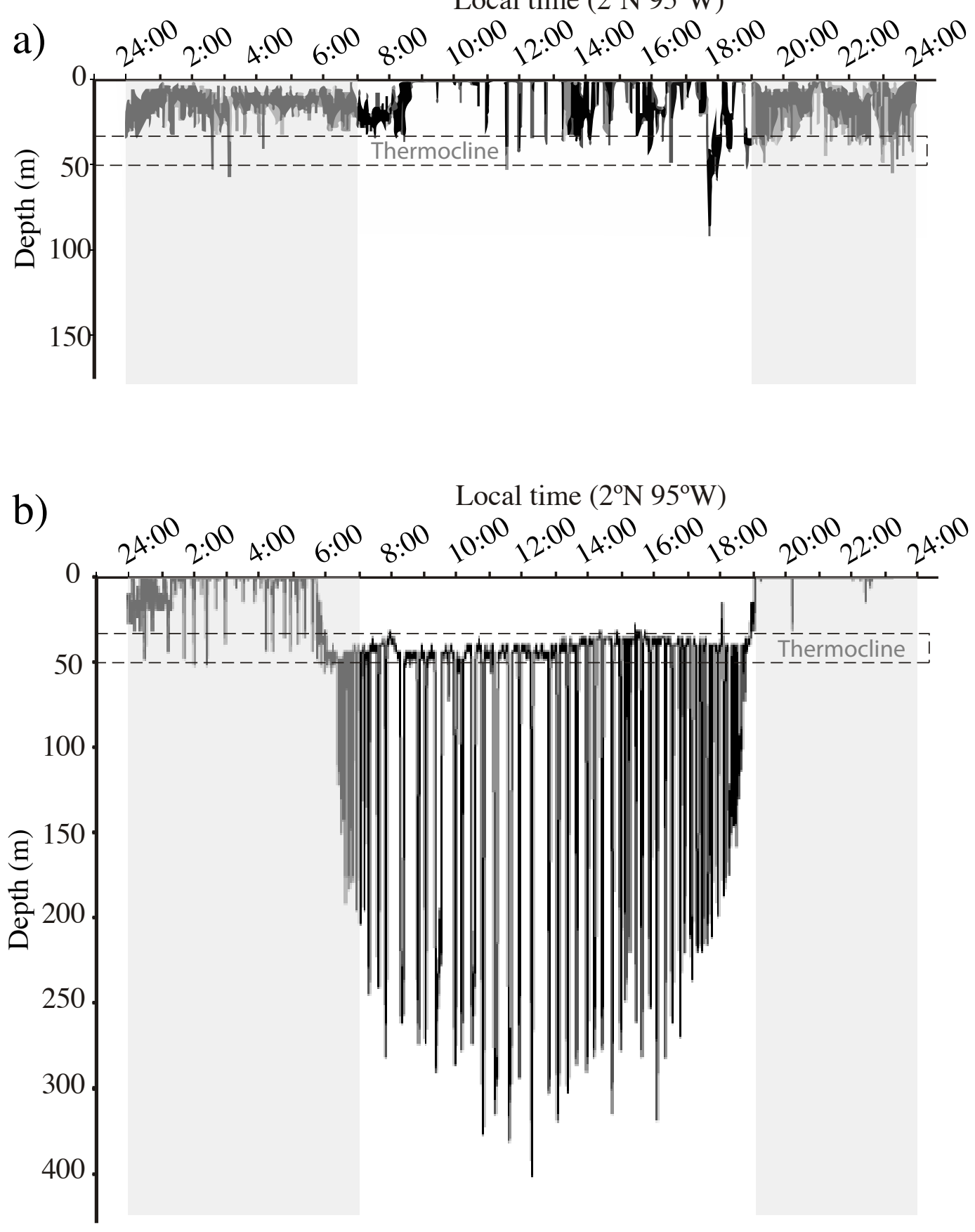

c)

Temperature $\left({ }^{\circ} \mathrm{C}\right)$

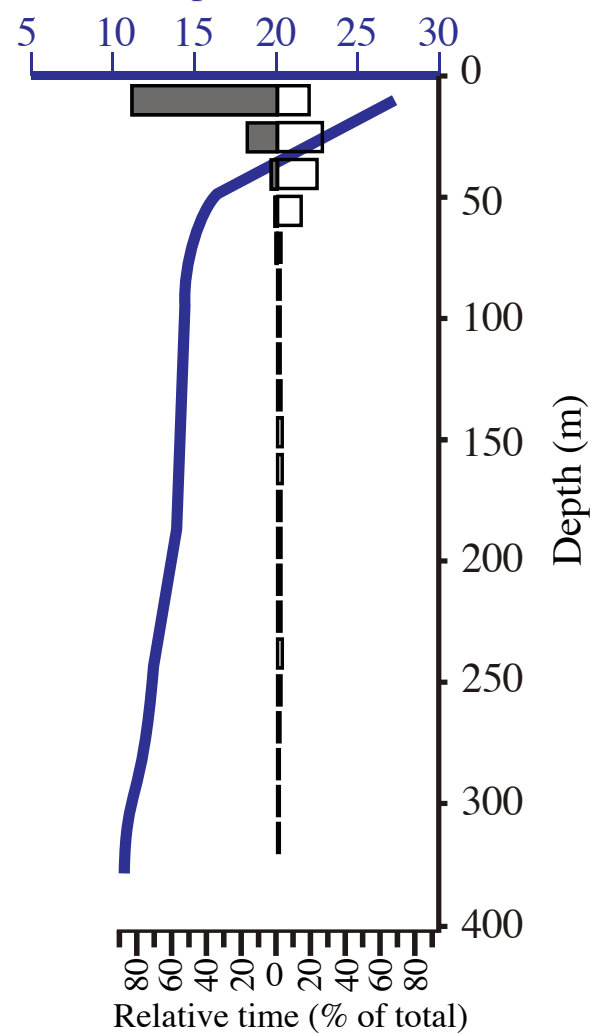

Figure 3. 
a)
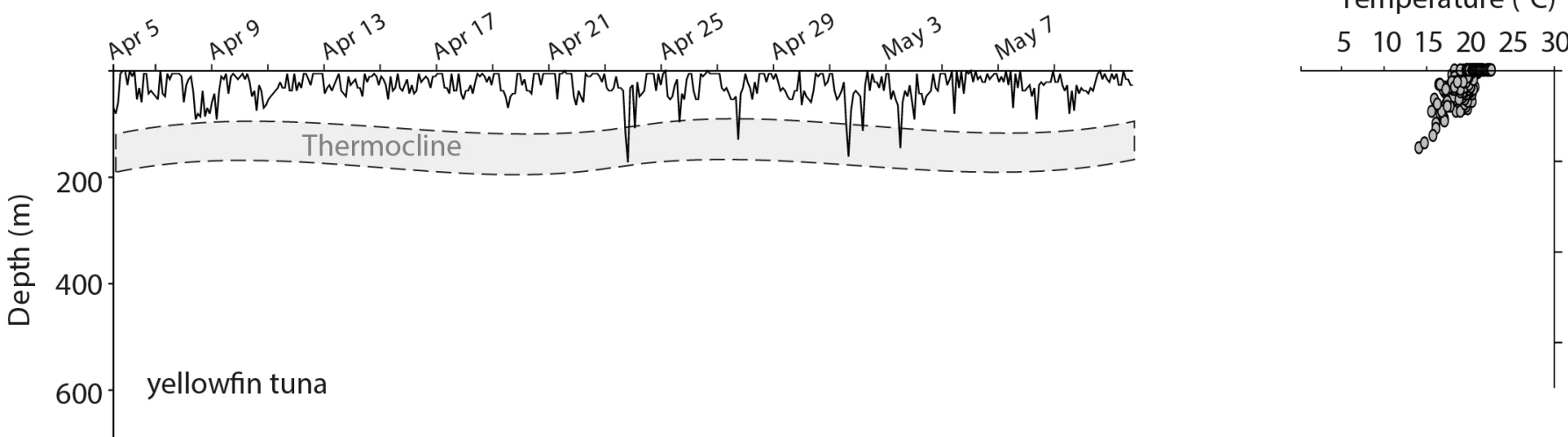

b)

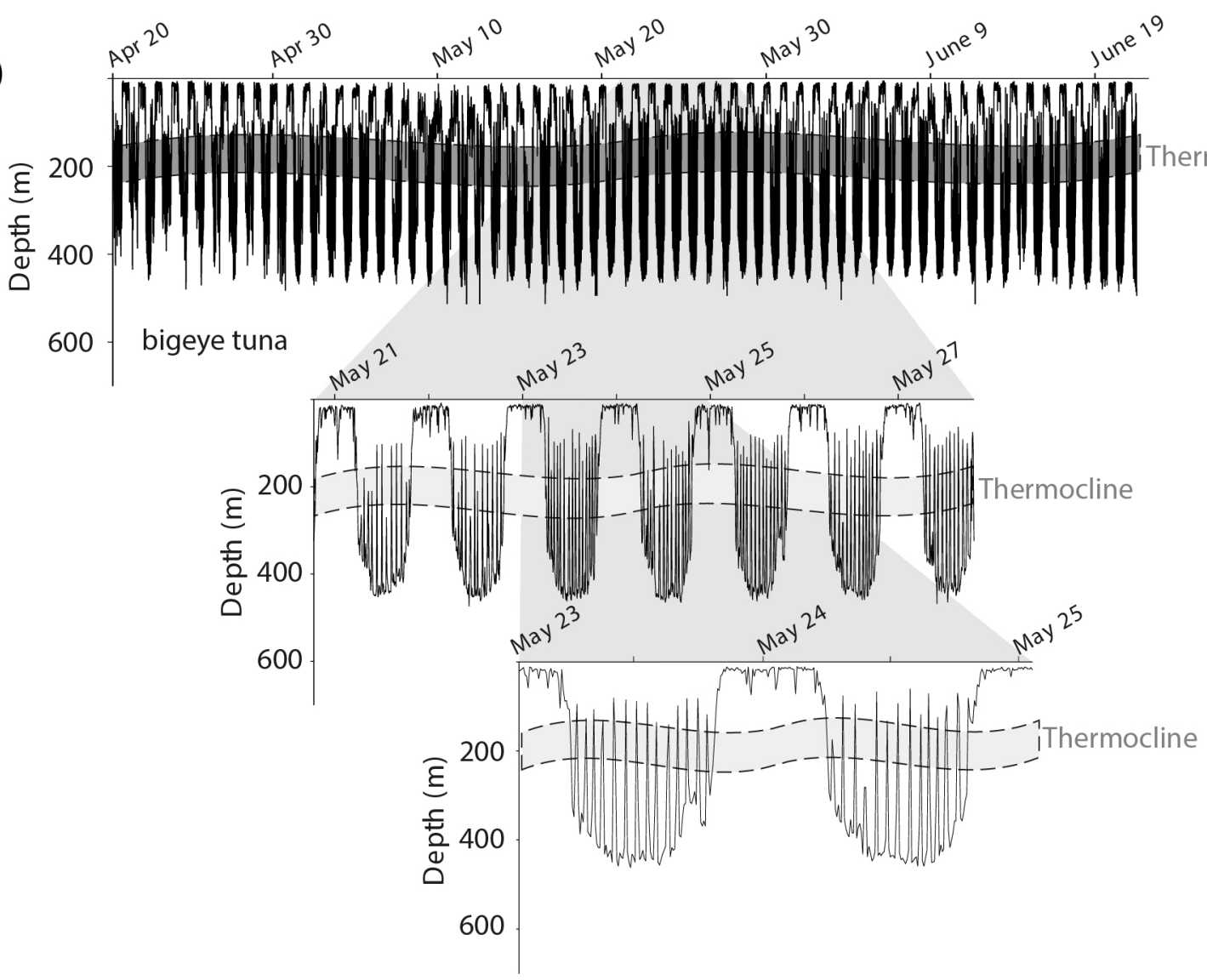

Temperature $\left({ }^{\circ} \mathrm{C}\right)$ $\begin{array}{llllll}5 & 10 & 15 & 20 & 25 & 30\end{array}$

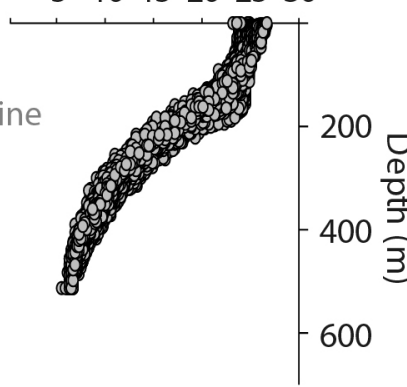

Figure 4. 


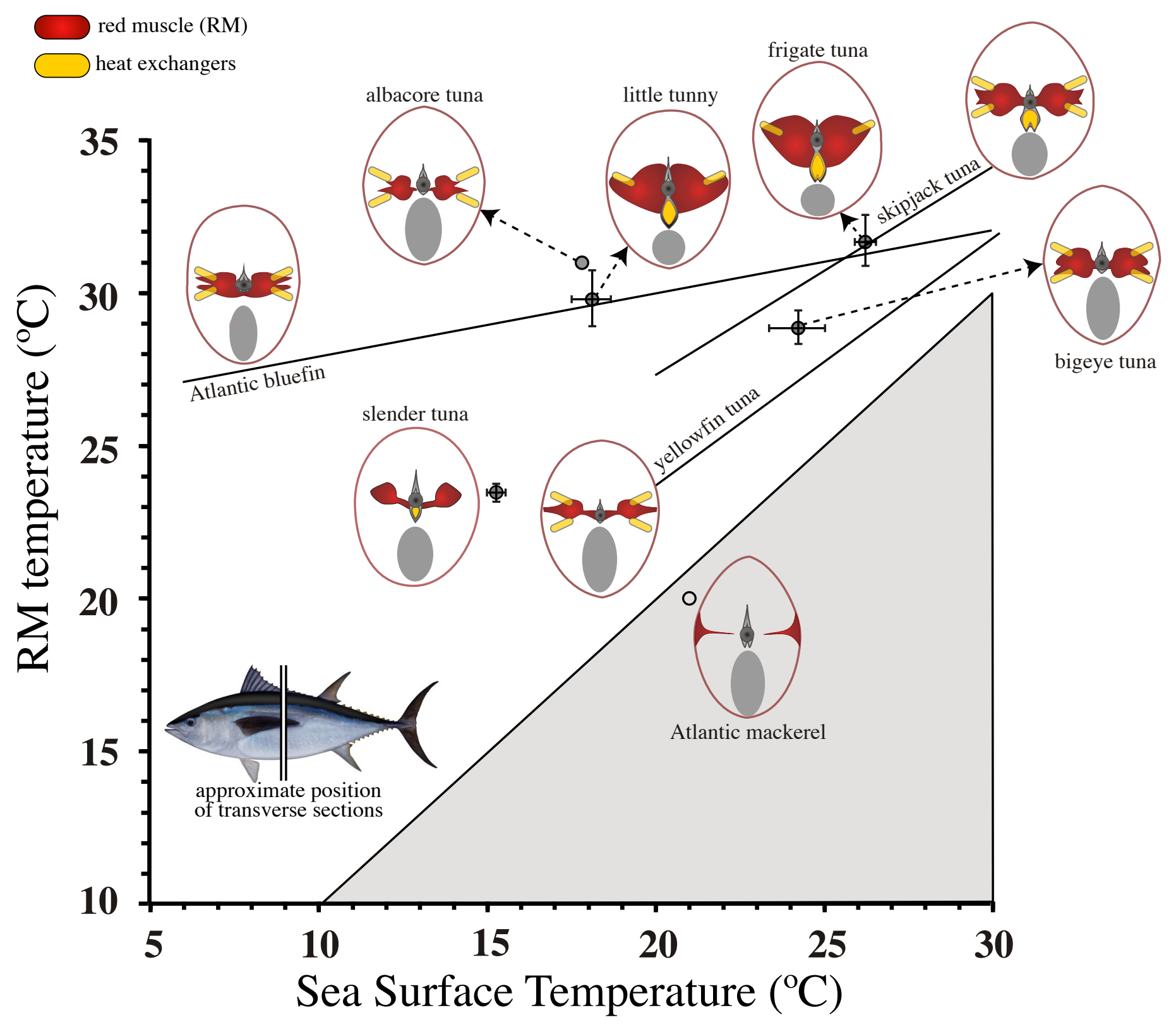

Figure 5 
a)

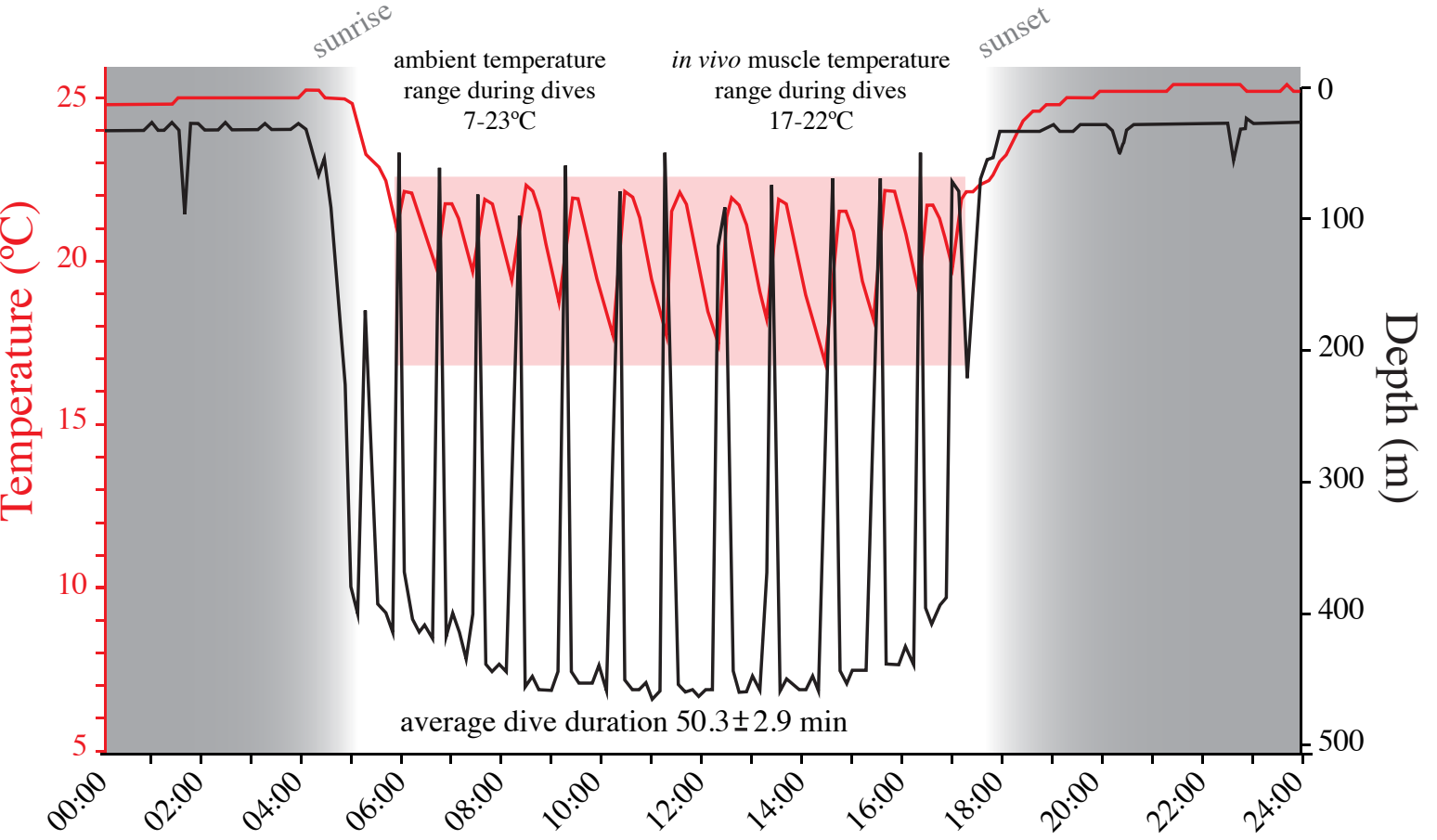

Time of day

b)

Day 21

Day 22

Day 23

Day 24

Day 28

Day 29

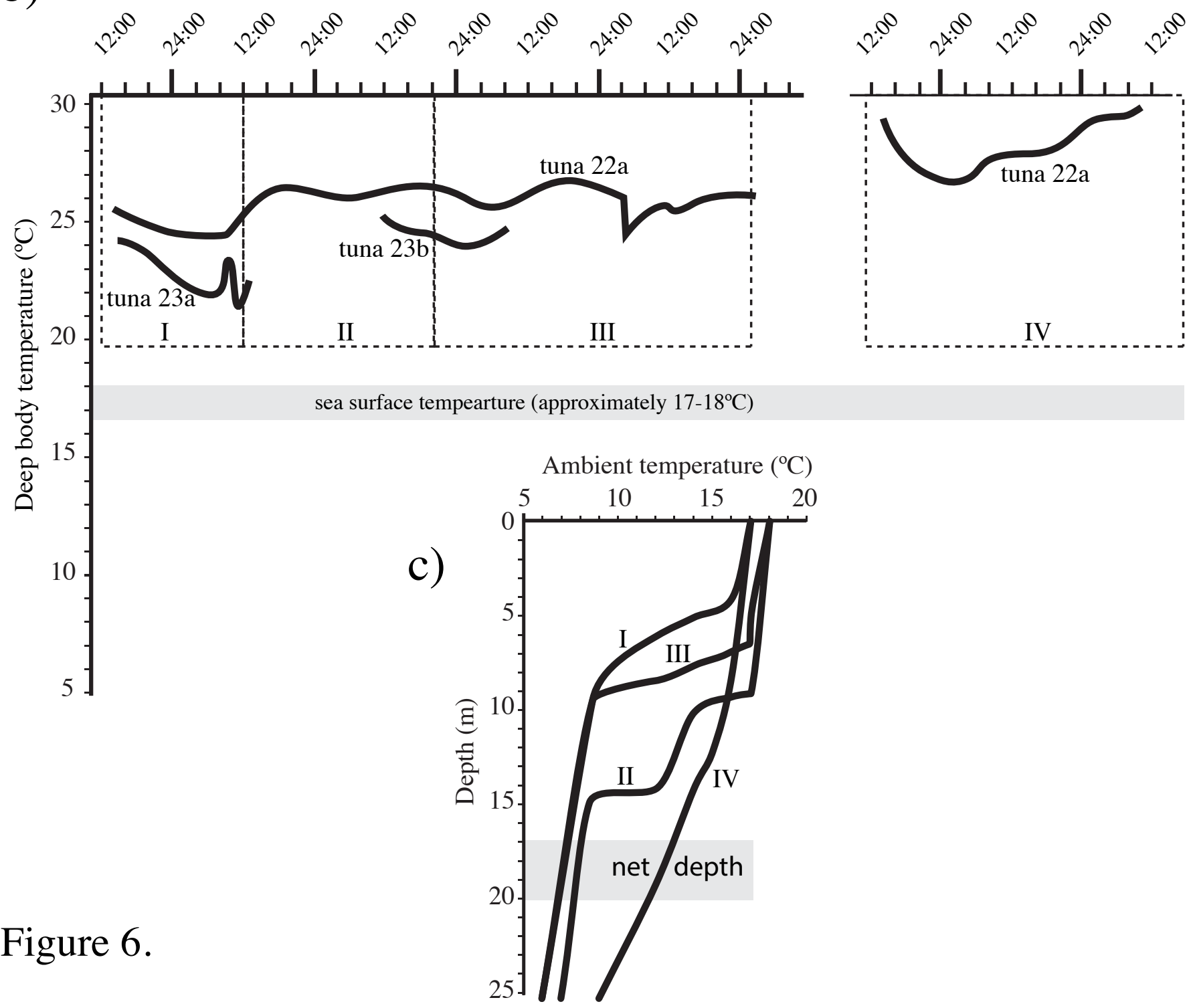




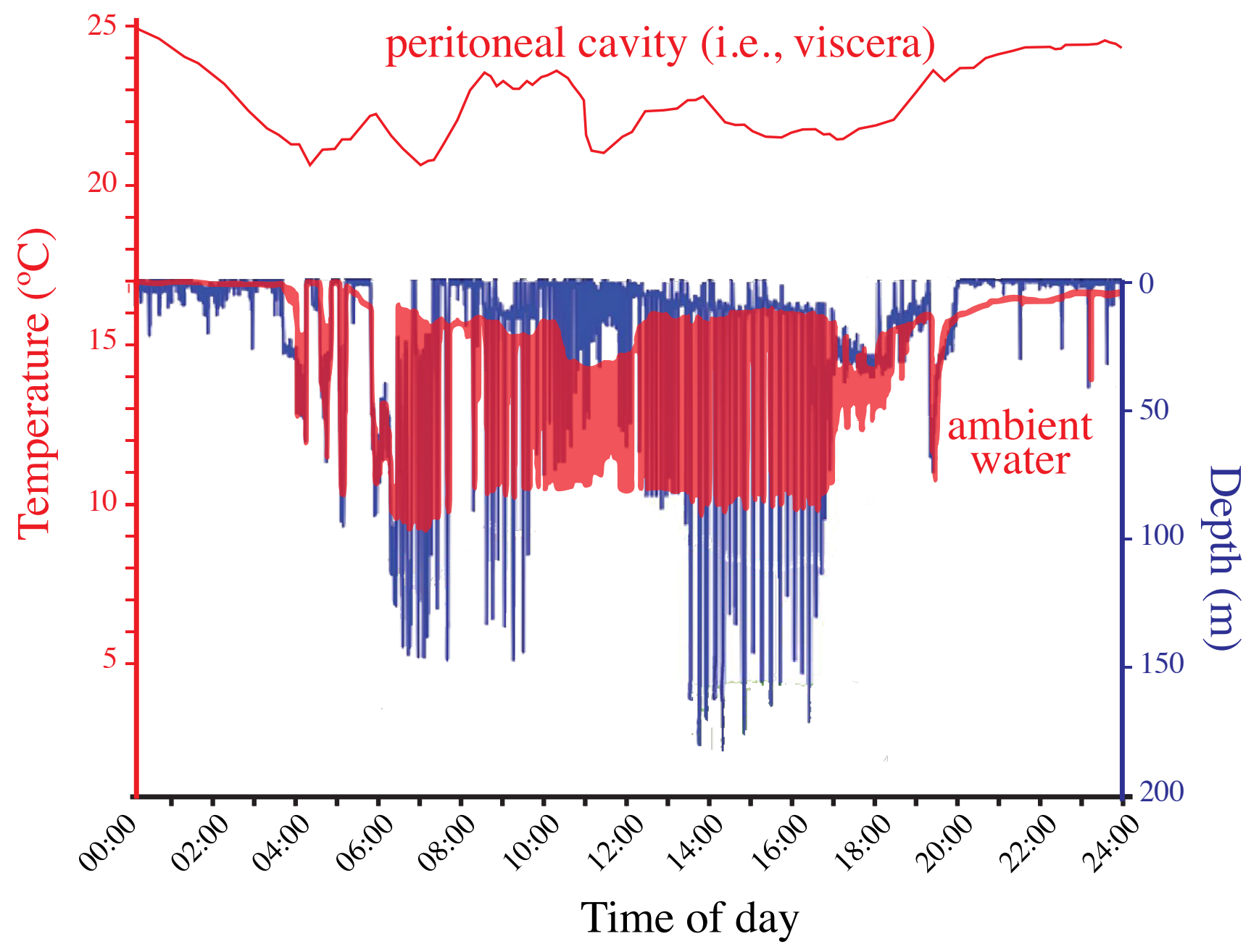

Figure 7 


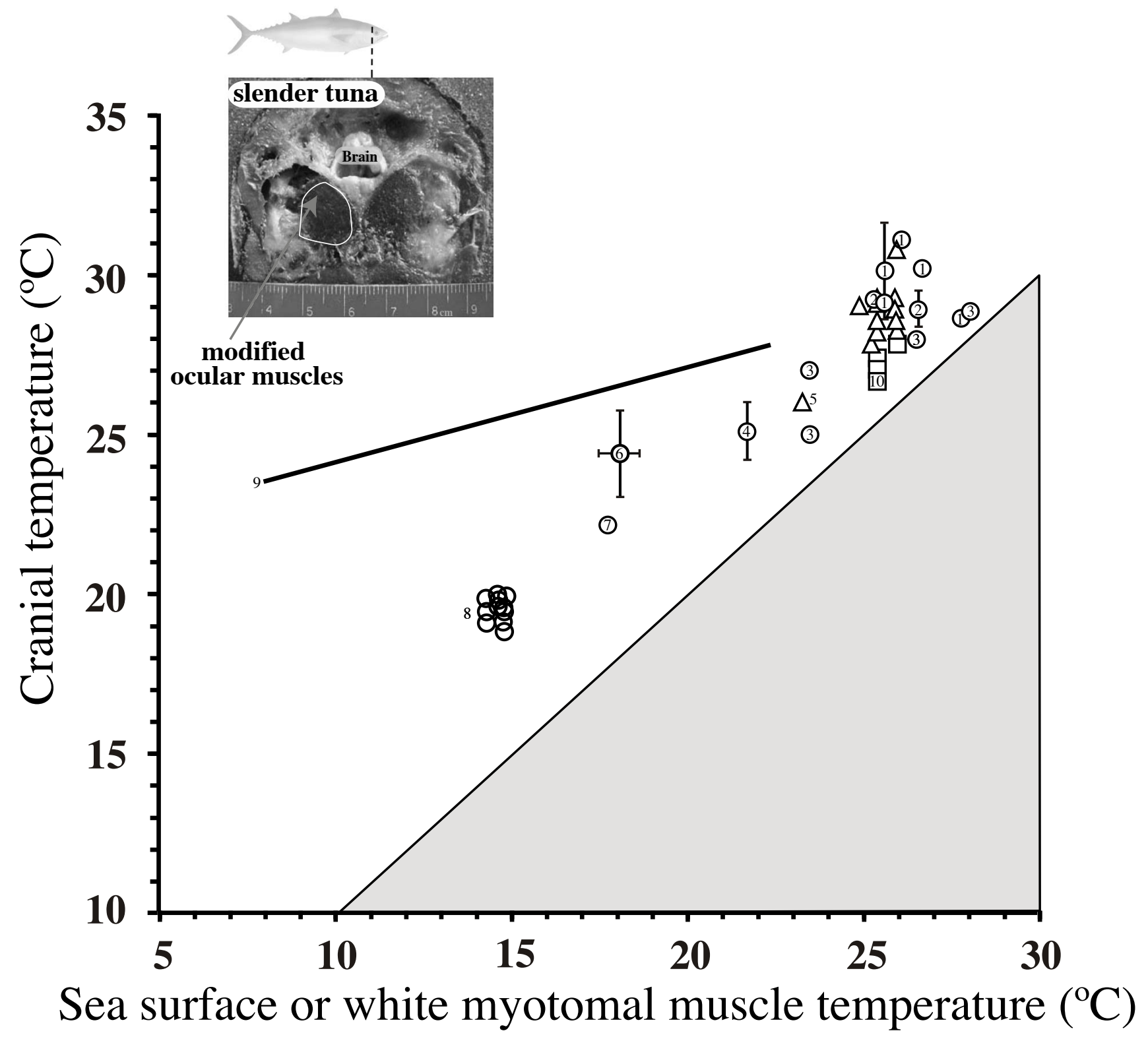

Figure 8 
a)

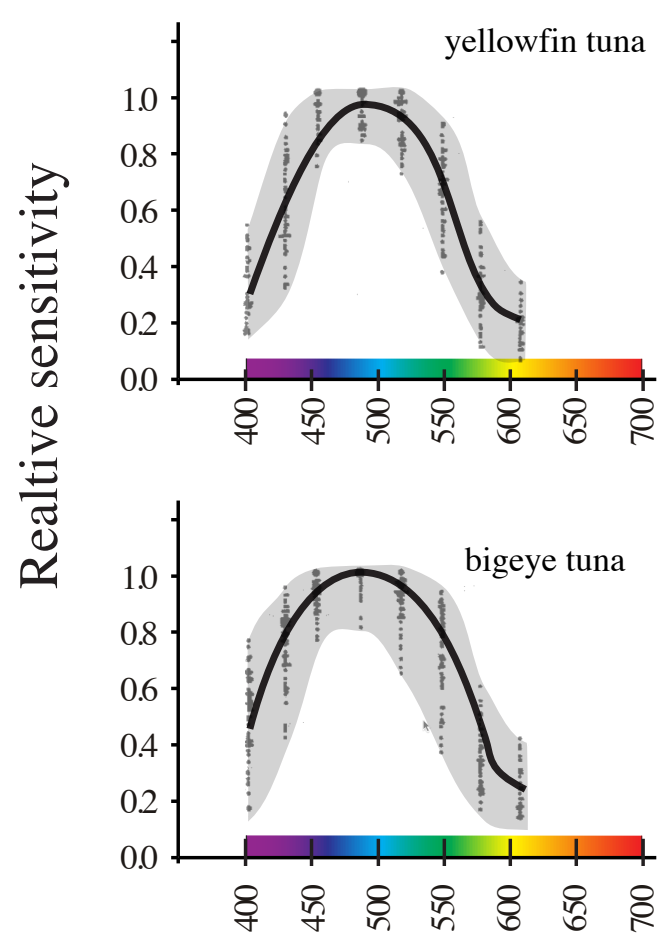

Visible light wavelength (nm)

b)

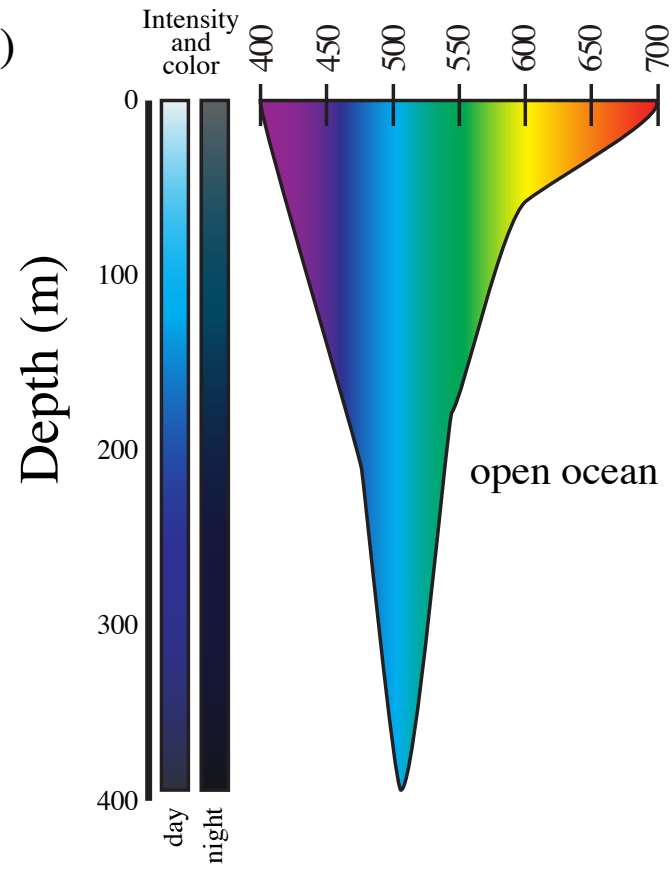

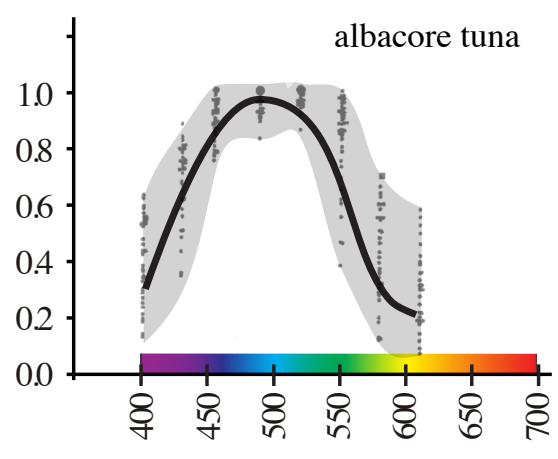

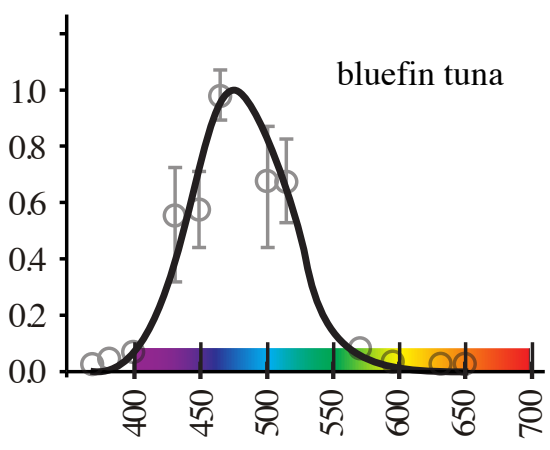

Visible light wavelength (nm)
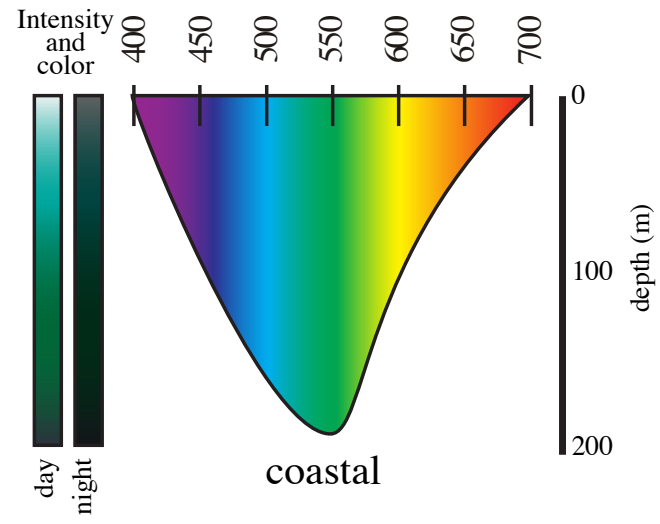

c)

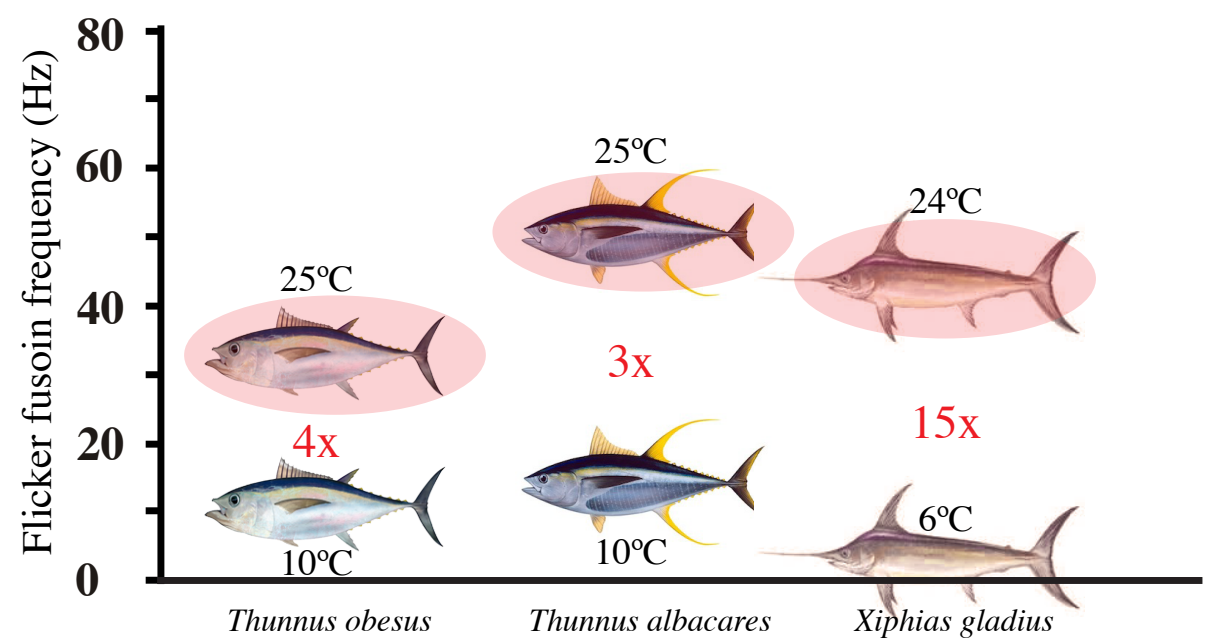

Figure 9. 
a)

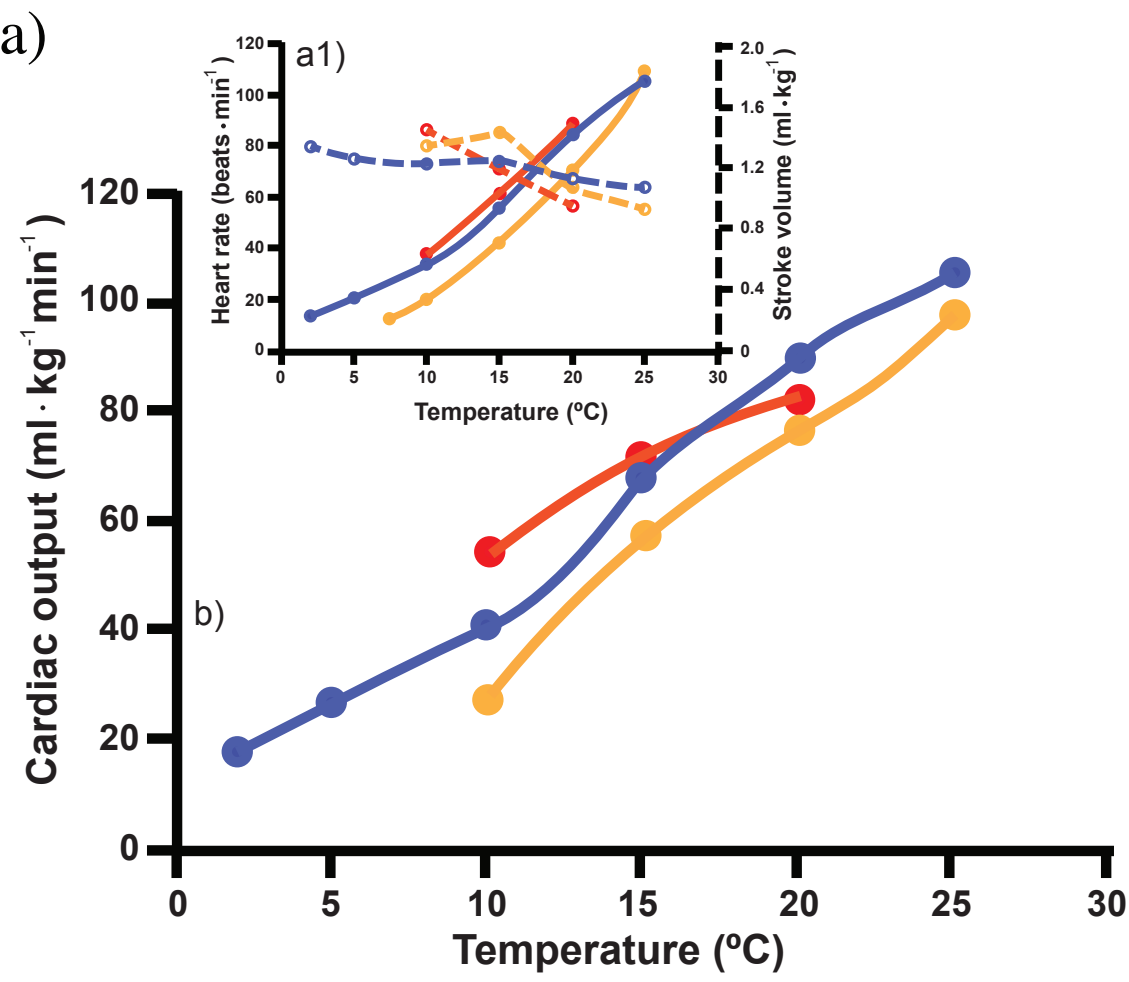

c)

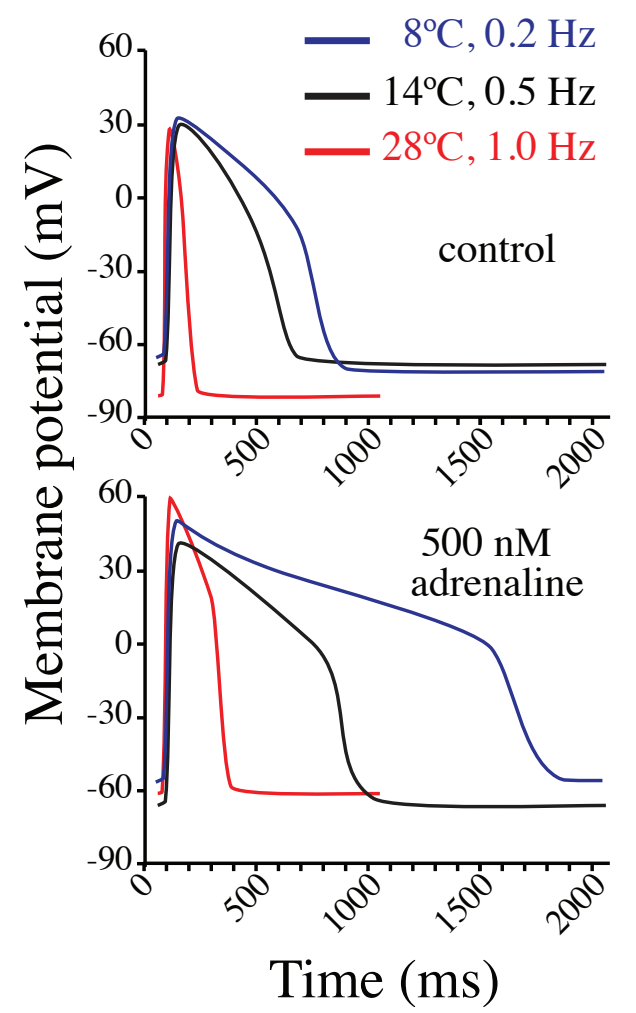

b)

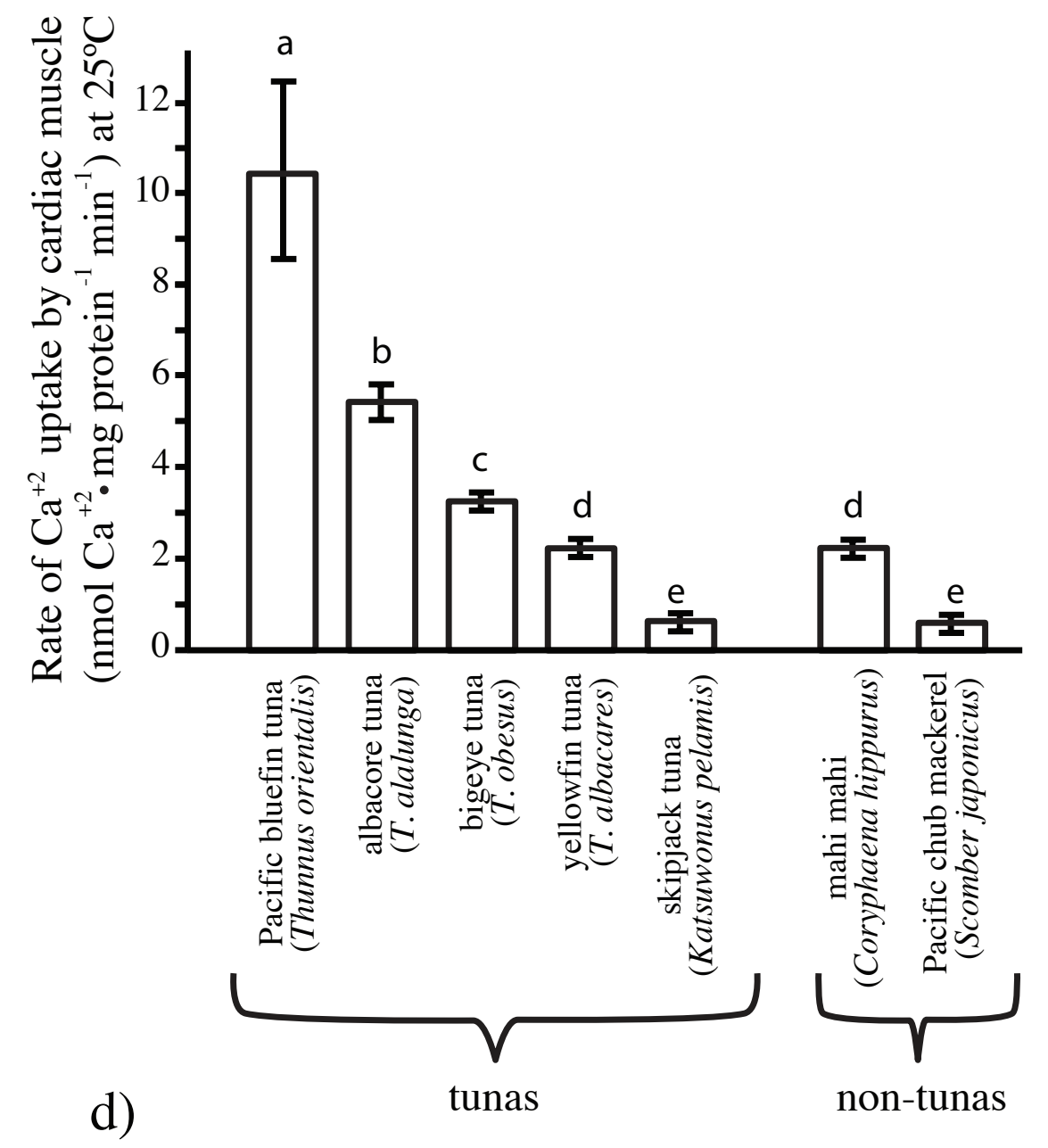

Figure 10

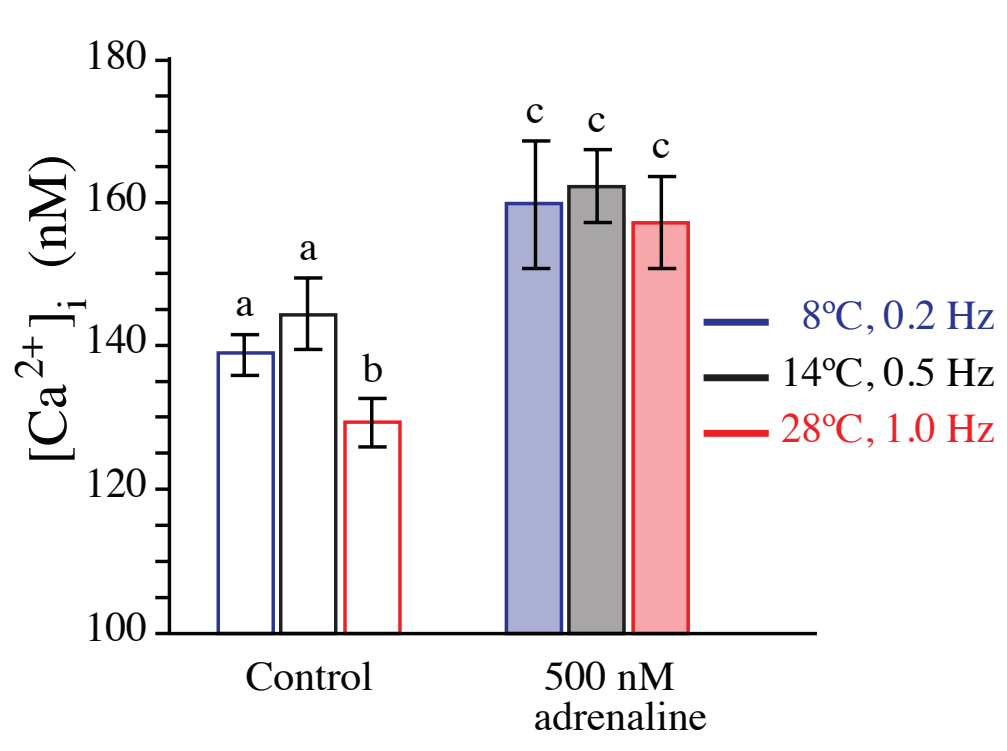


Fig. 1 a Phylogeny of the tunas (Tribe Thunnini) based on morphological and molecular characters. Modified from Graham and Dickson 2000; Miya et al. 2013; Diaz-Arce et al. 2016. b Transverse sections for the indicated species showing position of red muscle (RM) and the approximate location of vascular counter-current heat exchangers. Modified from Sepulveda et al. 2008. c Representative RM longitudinal distribution in albacore tuna (Thunnus alalunga) and the eastern Pacific bonito (Sarda chiliensis). The amount of RM at each position along the body (\% of fork length, FL) is expressed as a proportion of the amount of RM at $50 \%$ of fork length. The grey shaded areas represent the position where the relative amount of RM is maximal. Modified from Graham et al. 1983; Bernal et al. 2009.

Fig. 2 Representative vertical movement distribution patterns for tunas. Color fish images represent the average depth (combined night and day) for each species. Gray-filled fish outlines represent the depth at which each species spent $95 \%$ of the time during the night. Open outlines represent the depth at which each species spent $95 \%$ of the time during the day. Grey shaded bar represents the thermocline, defined as the depth range in which water temperature changes rapidly, separating the water column into the upper wellmixed surface layer (i.e., water above $20^{\circ} \mathrm{C}$, well oxygenated) and the cooler, deeper waters (i.e., below $15^{\circ} \mathrm{C}$ ). Group 1: Tunas that spend the majority of their time in the upper uniform-temperature surface layer (e.g., Auxis spp., Euthynnus spp., K. pelamis juveniles, T. albacares juveniles). Group 2: Tunas that undertake short excursions below the thermocline (e.g., adults of $K$. pelamis and T. albacares). Group 3: Tunas that spend significant periods in cool water at high latitudes (e.g., T. thynnus, T. alalunga) or below the thermocline (e.g., T. obesus). Modified from Musyl et al. 2004; Bernal et al. 2009.

Fig. 3 Representative vertical movement patterns for an adult skipjack tuna $(70 \mathrm{~cm}$ fork length) implanted with an archival tag swimming in the eastern equatorial Pacific Ocean. a On April 11, 2004, the tuna was in the vicinity of a floating object and showed surface oriented diving behavior characteristic of tunas in Group 1. b On April 18, 2004, the same individual showed repeated diving behavior to deeper water when in the open ocean. Grey shaded areas indicate nighttime. $\mathbf{c}$ Vertical thermal profile of the water column and (horizontal bars) the relative time spent at depth ( $15 \mathrm{~m}$ intervals) for five skipjack tuna swimming in the open ocean. Grey bars are relative time spent at depth during the night and white bars are relative time spent at depth during the day. Modified from Schaefer and Fuller 2007.

Fig. 4 Representative vertical movement patterns (left) and temperature-depth profiles (right) for a Group 2 yellowfin tuna and $\mathbf{b}$ Group 3 bigeye tuna. Inserts in $\mathbf{b}$ show an expanded 7-day time period and a detailed 48 -h time period. Date-marks indicate midnight of that day. Modified from Musyl et al. 2004; Bernal et al. 2009; M. Musyl and R. Brill, unpublished (data collected near the main Hawaiian Islands) 
Fig. 5 Red muscle temperature $\left(T_{R M}\right)$ as a function of sea surface temperature (SST) in tunas and the Atlantic mackerel. Grey shaded area represents a $\mathrm{T}_{\mathrm{RM}}$ below SST. Data are shown as mean \pm s.e.m. for slender tuna (Allothunnus fallai, $\mathrm{n}=30$ ), frigate tuna (Auxis thazard, $\mathrm{n}=7$ ), little tunny (Euthynnus alletteratus, $\mathrm{n}=16$ ), and bigeye tuna (Thunnus obesus, $\mathrm{n}=17)$. Individual data shown for Atlantic mackerel (Scomber scombrus, $\mathrm{n}=1$ ) and albacore tuna (Thunnus alalunga, $\mathrm{n}=1$ ); linear regressions are shown for Atlantic bluefin tuna (Thunnus thynnus, $\mathrm{n}=162 ; \mathrm{T}_{\mathrm{RM}}=25.84+0.206 \mathrm{SST}$ ), skipjack tuna (Katsuwonus pelamis, $\mathrm{n}=53, \mathrm{~T}_{\mathrm{RM}}=13.7+0.68 \mathrm{SST}$ ), and yellowfin tuna (Thunnus albacares, $\left.\mathrm{n}=62, \mathrm{~T}_{\mathrm{RM}}=7.47+0.81 \mathrm{SST}\right)$. Transverse section for each species showing medial position of RM and the approximate location of vascular counter-current heat exchangers. Modified from Sepulveda et al. 2008; Bernal et al. 2009.

Fig. 6 a Daily archival tag record of free-swimming bigeye tuna $(131 \mathrm{~cm}$ fork length, $44.5 \mathrm{~kg}$ ) off the Hawaiian coast, showing depth (black line) and internal body temperature (red line). Grey shaded areas indicate approximate light levels at sunrise and sunset. Internal temperature taken from a thermistor inserted several centimeters below the skin in the epaxial swimming muscles in close proximity to the first dorsal fin. Red shaded area shows the time during the day at which the fish repeatedly dove below the thermocline. Note that the muscle temperature does not decrease below $17^{\circ} \mathrm{C}$. Modified from Musyl et al. 2003. b Telemetry record for deep body (i.e., red muscle) temperature from four Atlantic bluefin tuna swimming in a sea-pen (maximum pen depth 17-20 m) off the coast of Nova Scotia. c Thermal profile of the water column during the four telemetry experiments (Roman numerals in b). Note that the deep body temperature of the tuna remains significantly above ambient temperature during the multiday experiment. All tuna were in excess of $400 \mathrm{~kg}$ dressed. Modified from Stevens et al. 2001.

Fig. 7 Archival tag record of free swimming juvenile Pacific bluefin tuna off the California coast, showing depth (blue) and ambient and peritoneal (red line) temperatures. Juvenile bluefin tuna demonstrate rapid bouts of diving associated with foraging behavior that occur prior to a visceral heat increment of feeding event (peritoneal warming). This "bounce diving," where time at depth is short and interspersed regularly with time at the surface, may be related to cold-induced cardiac bradycardia and subsequent oxygen delivery limitations at depth. Modified from Shiels et al. 2015.

Fig. 8 Cranial temperature as a function of sea surface temperature (SST) or white myotomal (WM) temperature in tunas. Grey shaded area represents a cranial temperature below SST or WM temperature. Insert shows potential heater tissue in the slender tuna. Species-specific data are identified by number: $1=$ Auxis thazard $(\mathrm{n}=5) ; 2=$ Katsuwonus pelamis $(\mathrm{n}=29) ; 3=$ Euthynnus lineatus $(\mathrm{n}=4) ; 4=$ small Thunnus thynnus $(\mathrm{n}=6) ; 5=T$. obesus (triangles); $6=$ E. alletteratus $(\mathrm{n}=16) ; 7=$ T. alalunga; $8=$ Allothunnus fallai; $9=$ giant T. thynnus; $10=T$. albacares (squares). Values are individual data points or mean $\pm \mathrm{SD}$, 
linear regressions shown for giant $T$. thynnus [cranial temperature $=21.1+0.3 \mathrm{SST}$ ). Data from Stevens and Fry 1971; Linthicum and Carey 1972; Schaefer 1984, 1985; Sepulveda et al. 2007; Runcie et al. 2009; C. Sepulveda unpublished.

Fig. 9 a Relative spectral sensitivity in the eyes of four tuna species (Thunnus spp.). Raw data shown, shaded bars indicate range and solid line approximates the mean response; values for bluefin tuna $(n=6)$ are mean \pm S.D. b Representative color, intensity and visible light spectral penetration in oceanic and coastal waters. $\mathbf{c}$ Daytime speed of vision (i.e., flicker fusion frequency, FFF) in the eyes of bigeye and yellowfin tunas and swordfish at ambient temperature and at in vivo temperatures (i.e., cranial endothermy; red shaded images). Ambient and in vivo temperature (black values) shown next to images and the approximate fold-increase in FFF due to elevated cranial temperatures are shown in red. Modified from Kawamura et al. 1981a; Fritsches et al. 2005; Matsumoto et al. 2009; Horodysky et al. 2016.

Fig. 10 Comparison of in situ cardiac performance in albacore tuna (red), bluefin tuna (blue) and yellowfin tuna (yellow). a Cardiac output, recorded in isolated perfused spontaneously beating hearts. a1 Maximal values of heart rate and stroke volume. b Rate of $\mathrm{Ca}^{2+}$ uptake catalyzed by SERCA2 in ventricular homogenates from different fish species at $25^{\circ} \mathrm{C}$. $\mathbf{c}$ Effect of acute temperature changes, contraction frequency, and adrenergic stimulation $(500 \mathrm{nM})$ on the action potential and $\mathbf{d}$ on the peak intracellular $\mathrm{Ca}^{2+}$ transient $\left(\left[\mathrm{Ca}^{2+}\right]_{\mathrm{i}}\right)$ in Pacific bluefin tuna ventricular myocytes. Slowing of contraction frequency (as indicated by $\mathrm{Hz}$ in the legend) and adrenergic stimulation (500 $\mathrm{nM}$ ) both prolong action potential duration, which together normalize the $\left[\mathrm{Ca}^{2+}\right]_{i}$. Values in a are means \pm s.e.m. [bluefin tuna, $n=3\left(2^{\circ} \mathrm{C}\right), \mathrm{n}=4\left(10,20,25^{\circ} \mathrm{C}\right), \mathrm{n}=5\left(5^{\circ} \mathrm{C}\right), \mathrm{n}=6$ $\left(15^{\circ} \mathrm{C}\right)$; yellowfin tuna, $n=4\left(10,25^{\circ} \mathrm{C}\right), \mathrm{n}=5\left(15^{\circ}, 20^{\circ} \mathrm{C}\right)$; albacore tuna, $\left.n=1\right]$. Values in $\mathbf{b}$ represent the average \pm s.e.m. of at least three experiments performed with preparations from three individual fish and $\mathbf{c}$ are means \pm s.e.m. for 8-11 myocytes. Dissimilar letters in $\mathbf{b}$ and $\mathbf{d}$ show significant differences; ANOVA, $\mathrm{P}<0.05$. Effects of adrenaline in $\mathbf{c}$ are significant (not shown). Modified from Blank et al. 2004; Landeira-Fernandez et al. 2004; Shiels et al. 2015. 